Portland State University

PDXScholar

\title{
An examination of moral boundaries associated with legal and social changes in response to the AIDS epidemic
}

Lauri Sue Johnson

Portland State University

Follow this and additional works at: https://pdxscholar.library.pdx.edu/open_access_etds

Part of the Sociology Commons

Let us know how access to this document benefits you.

\section{Recommended Citation}

Johnson, Lauri Sue, "An examination of moral boundaries associated with legal and social changes in response to the AIDS epidemic" (1992). Dissertations and Theses. Paper 4320.

https://doi.org/10.15760/etd.6204

This Thesis is brought to you for free and open access. It has been accepted for inclusion in Dissertations and Theses by an authorized administrator of PDXScholar. Please contact us if we can make this document more accessible: pdxscholar@pdx.edu. 
AN ABSTRACT OF THE THESIS OF Lauri Sue Johnson for the Master of

Science in Sociology presented June 10, 1992.

Title: An Examination of Moral Boundaries Associated with Legal and Social Changes in Response to the AIDS Epidemic.

APPROVED BY THE MEMBERS OF THE THESIS COMMITTEE:

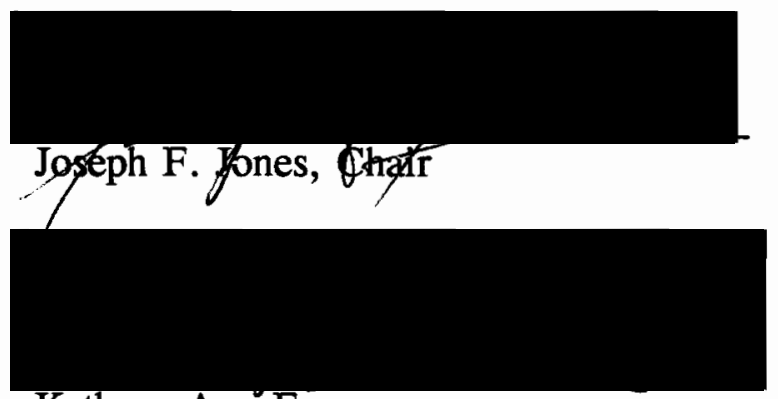

Kathryn Ann Farr

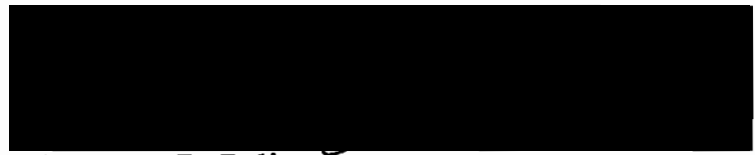

Annette I. Jolin

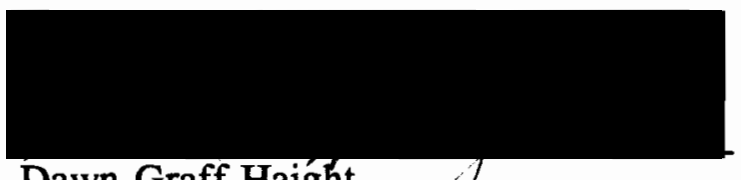

This thesis explores the relationship between law and society and various forms of causality: (1) legal change leading to social change; (2) social change leading to legal change; and (3) the interdependent interaction between social 
change and legal change. It is proposed that a multi-directional approach would be the most useful in examining the moral boundaries exemplified in the law identified with legal and social changes that have resulted in response to the AIDS epidemic.

Three social institutions are focused on in this examination: business/ employment, education (access questions), and medical care delivery. These three institutions were selected as representing varying degrees of governmental control (e.g., business/employment illustrating the least and medical care delivery illustrating the most). In addition, the selected institutions portray separate aspects of social life which involve emotional issues such as the rights of the individual versus the rights of society.

A legal computer databank known as LEXIS/NEXIS was utilized to obtain a complete listing of the reported federal court cases and appellate state court cases in the United States relating to AIDS issues. Each case was then analyzed using content analysis, allowing each one to be identified as relating to one of the three selected institutions. In addition, each AIDS case that dealt with the three institutions was categorized as focusing on personal or public rights, and whether it maintained the status quo or caused modification and thus construction in existing boundaries.

Moral boundaries were also examined from a social standpoint by applying the same dictionary of identifiers and categories employed to assess legal changes to newspaper article summaries from January 1981 through December 1991 from The New York Times Summary Index and from the Newspaper Index, a 
newspaper databank which indexes articles focusing on local and regional stories in and around Oregon.

The findings indicate that the relationship between legal change and social change is in fact an interactive process. While the data identified with each of the three institutions illustrate this interaction, they are at different stages of the moral boundary maintenance or construction efforts in response to the AIDS epidemic. An analysis of the findings also suggests that as moral boundaries associated with business/employment, access to education and medical care delivery shift from a construction to maintenance phase, the number of legal and social challenges diminishes in response to the AIDS epidemic.

The findings relating to whether legal and social changes focus on personal or public rights issues differ. The newspaper articles used to represent social attitudes and values indicate an almost equal percentage of articles dealing with personal as with public rights issues. The main difference is found when looking at legal decisions wherein an overwhelming majority of the cases deal with personal rights issues. This may be explained in part by the nature of bringing a legal action in the United States judicial system. It has been traditionally more difficult to bring and litigate a matter on behalf of a large number of people (class action), or to represent a social group, than it is to name one or a few individuals as plaintiffs. 


\title{
AN EXAMINATION OF MORAL BOUNDARIES ASSOCIATED \\ WITH LEGAL AND SOCIAL CHANGES IN \\ RESPONSE TO THE AIDS EPIDEMIC
}

\author{
by
}

LAURI SUE JOHNSON

A thesis submitted in partial fulfillment of the requirements for the degree of

\section{MASTER OF SCIENCE in SOCIOLOGY}

Portland State University

1992 


\section{TO THE OFFICE OF GRADUATE STUDIES:}

The members of the Committee approve the thesis of Lauri Sue Johnson presented June 10, 1992.
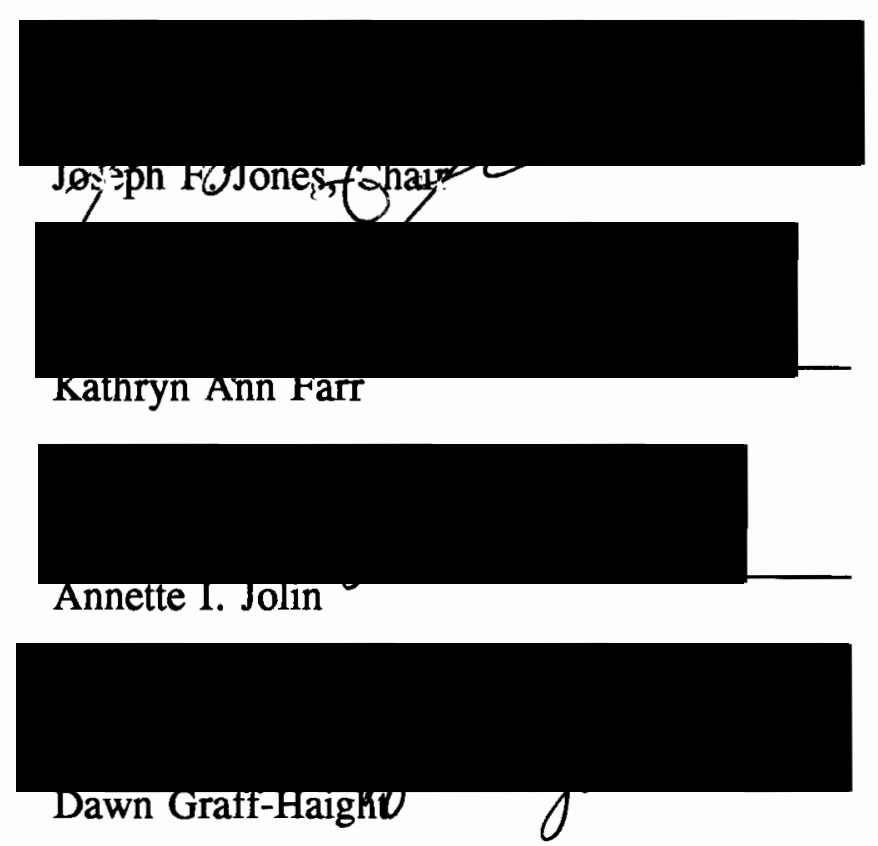

\section{APPROVED:}

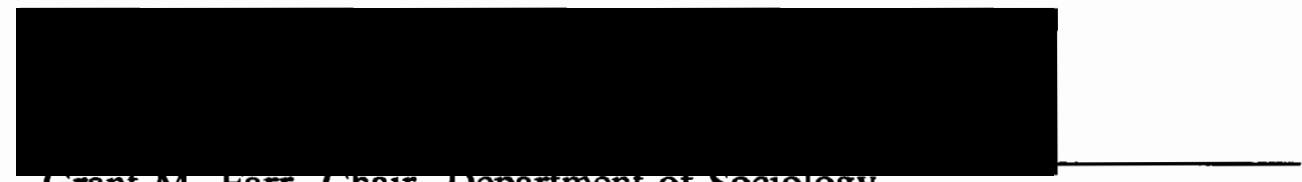

Grant iv. Fari, Cnair, Department or sociology

C. Wiliam Savery, vice Provost for Graduate studies and Research 


\section{ACKNOWLEDGMENTS}

I want to take this opportunity to thank those individuals who helped me make the completion of this thesis a reality. Most importantly, I want to thank my parents Joel and Dolores Johnson for their full support and belief in me no matter what my current endeavor might be. I want to thank Stephanie Freedman who encouraged me to return to college full-time. I want to thank Dennis Elliott, Stephanie Freedman, and David Park for allowing me to work flexible hours to complete my undergraduate and graduate degrees. I want to thank my committee members for the time they took to work with me, and for their suggestions and comments. And, I want to especially thank Dr. Joseph Jones for his comments, reassurances, insights, advice, and friendship throughout this process, because without him, this thesis would not be what it is. 
TABLE OF CONTENTS

PAGE

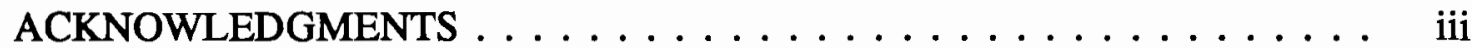

LIST OF TABLES $\ldots \ldots \ldots \ldots \ldots \ldots \ldots \ldots \ldots$ vii

\section{CHAPTER}

I THEORETICAL FRAMEWORK AND BACKGROUND $\ldots \ldots \ldots$

Statement of the Problem $\ldots \ldots \ldots \ldots \ldots$

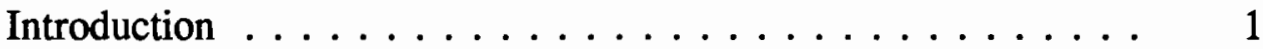

Theoretical Framework $\ldots \ldots \ldots \ldots \ldots \ldots \ldots$

The Meaning of "Law"

Law and Society

Classical Approach

Contemporary Approach

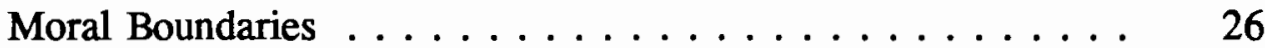

Background . . . . . . . . . . . . . . . . 27

AIDS, the Disease

Social Milieu

Constructing Moral Boundaries

Early Legislative Activity

Maintaining Moral Boundaries

II METHODOLOGY $\ldots \ldots \ldots \ldots \ldots \ldots \ldots \ldots \ldots \ldots$

Summary of Methodology $\ldots \ldots \ldots \ldots \ldots \ldots$

Introduction . . . . . . . . . . . . . . 54

Selection of Areas . . . . . . . . . . . . . 55

Business/Employment

Access to Education

Medical Care Delivery 
Mass Media and Use of Content Analysis . . . . . . . . . 57

Selection of Media Sources

Content Analysis Criteria

The New York Times

Newspaper Index

Judicial System . . . . . . . . . . . . . . . . 65

Personal (Individual) and Public Rights . . . . . . . . . 67

Newspaper Articles

Legal Decisions

Moral Boundary Construction and Maintenance . . . . . . . 69

Newspaper Articles

Legal Decisions

Intercoder Reliability $\ldots \ldots \ldots \ldots \ldots \ldots \ldots$

Jurisprudence Precedence . . . . . . . . . . . . . 71

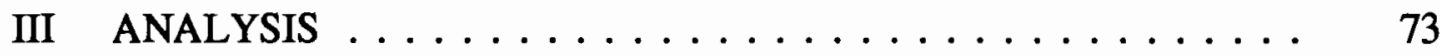

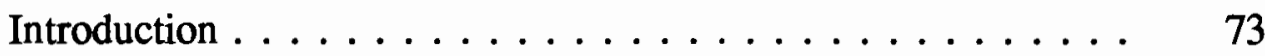

Socially Defined Problems . . . . . . . . . . . . 74

Mass Media - Newspaper Articles . . . . . . . . 75

High Visibility Individuals . . . . . . . . . . . . . . 79

Legislative Activity . . . . . . . . . . . . . 81

Individual/Public Rights and Moral Boundaries . . . . . . . 84

Media Exposure

Jurisprudence

Important Case Law Relevant to Business/

Employment, Access to Education, and

Medical Care Delivery . . . . . . . . . . . . . . . . 95

Business/Employment

Access to Education

Medical Care Delivery 
IV SUMMARY AND CONCLUSION $\ldots \ldots \ldots \ldots \ldots \ldots$

Summary of Theoretical Framework $\ldots \ldots \ldots \ldots \ldots$

Summary of Methodology . . . . . . . . . . . . . 120

Summary of Analysis . . . . . . . . . . . . . . 122

Summary of Additional Questions . . . . . . . . . 125

Summary of Additional Legal Decisions . . . . . . . . 128

Thoughts for Future Research . . . . . . . . . . . . 129

Conclusion . . . . . . . . . . . . . . . . . 129

REFERENCES .......................... 131

APPENDICES

A DICTIONARY OF IDENTIFIERS FOR BUSINESS/

EMPLOYMENT, ACCESS TO EDUCATION, AND

MEDICAL CARE DELIVERY . . . . . . . . . . .

B COMPLETE LISTING OF COURTS CONTAINED IN

GENERAL FEDERAL LIBRARY OF LEXIS/NEXIS

COURTS FILE . . . . . . . . . . . . . . . . . . 140

C COMPLETE LISTING OF COURTS CONTAINED IN

STATES LIBRARY OF LEXIS/NEXIS COURTS FILE . . . . . 144

D DICTIONARY OF IDENTIFIERS FOR PERSONAL

(INDIVIDUAL) AND PUBLIC RIGHTS . . . . . . . . . . 150

E DICTIONARY OF IDENTIFIERS FOR MORAL

BOUNDARY CONSTRUCTION AND MAINTENANCE . . . . . 


\section{LIST OF TABLES}

TABLE

PAGE

I National and Local/Regional Newspaper Articles Pertaining to AIDS and Business/Employment, Access to Education, and Medical Care Delivery Issues 1981 through 1991 . . . . .

II Legal Decisions in the United States Federal and State Courts Pertaining to AIDS and Business/Employment, Access to Education, and Medical Care Delivery Issues 1981 through $1991 \ldots \ldots \ldots \ldots \ldots \ldots \ldots \ldots \ldots$

III National and Local/Regional Newspaper Articles Pertaining to Personal and Public Rights re AIDS and Business/ Employment, Access to Education, and Medical Care Delivery Issues 1981 through $1991 \ldots \ldots$. . . . . . . . . .

IV National and Local/Regional Newspaper Articles Pertaining to Moral Boundary Construction and Maintenance re AIDS and Business/Employment, Access to Education, and Medical Care Delivery Issues 1981 through 1991 . . . . . . . . . . .

V Legal Decisions in the United States Federal and State Courts Pertaining to Personal and Public Rights re AIDS and Business/Employment, Access to Education, and Medical Care Delivery Issues 1981 through $1991 \ldots \ldots$. . . . . . . . 
VI Legal Decisions in the United States Federal and State Courts

Pertaining to Moral Boundary Construction and Maintenance

re AIDS and Business/Employment, Access to Education, and

Medical Care Delivery Issues 1981 through $1991 \ldots$. . . . . 93 


\section{CHAPTER I}

\section{THEORETICAL FRAMEWORK AND BACKGROUND}

\section{STATEMENT OF THE PROBLEM}

What is the nature of the relationship between moral boundaries (a consensus on norms, values and mores) and de jure rules of acceptable behavior created and maintained in a society? The relationship between law and society can be viewed as involving various forms of causality: (1) legal change leading to social change; (2) social change leading to legal change; or (3) the interdependent interaction between social change and legal change. It seems reasonable that a multi-directional approach to the relationship between law and society can be examined through the myriad ways in which moral boundaries in American society have been and are being shaped through legal responses to the Acquired Immunodeficiency Deficiency Syndrome (AIDS) epidemic. Three major social institutions will be selected to assess the direction of causality, both to more clearly focus on the process, and to make manageable the overwhelming volume of literature and number of sources dealing with AIDS issues.

\section{INTRODUCTION}

Throughout history, natural and human-produced phenomena have encouraged and even mandated both major and minor changes in patterns of conduct. At times, these behavioral modifications have been conceived and acted out through individual actions; at other times they have been imposed, regulated and 
enforced upon the individual by society for the benefit and protection of the individual or for what seems to be for the public's good. Modifications such as these have been particularly noticeable during times when social environment and human experience each attempt to adjust to the onset of epidemic diseases by reevaluating and sometimes redefining previously acceptable social, cultural and moral values. These adjustments very often take the form of shifts in rules, guidelines, regulations, policies and laws.

What are appropriate responses by the government and individuals to medical epidemics? To what extent can demands by each entity be made and carried out before civil rights of the individual are violated or before society is perceived as being threatened by the individual? These questions, in addition to many others, are currently being considered as various interest groups in the United States are attempting to deal with the AIDS epidemic. While AIDS and the numerous medical, social and cultural issues relating to this disease are not confined to the United States, this thesis will concentrate on the actions, reactions and responses taken in the United States.

As a background to looking specifically at the legal response in the United States to the AIDS epidemic, a general overview of the underlying relationship between law and society is provided in an attempt to address the questions which follow.

The relationship between law and society can be viewed as involving various forms of causality: (1) legal change leading to social change; (2) social change leading to legal change; or (3) the interdependent interaction between social change and legal change.

It appears that the relationship between law and society can be subjected to an examination of the myriad ways in which moral boundaries, as evidenced by 
legal codes in the United States society, have been and are being shaped through legal responses to the AIDS epidemic. On the surface it may appear that monetary awards for alleged wrongdoings illustrate a legal change leading to social change, and that human rights issues illustrate a social change leading to legal change. However, in a simple straight forward conception of cause and effect, in-depth analysis suggests that the causal relationship between law and society is instead interrelated and interdependent. One issue to be explored is that of how institutional and individual rights in the United States have been directly and indirectly affected and redefined as a result of legislative rules and court activity since the early 1980's in response to the AIDS epidemic.

In addition to analyzing the causal relationships between society and laws in response to the AIDS epidemic, the following questions will be explored, adding further depth to the analysis.

1. Given the dynamic nature of society, how are laws used to construct and maintain the moral boundaries of a society?

2. With regard to the AIDS epidemic, are laws and legislation in the United States merely a reflection of dominant social values, or instead, is society deterministically regulated by the law?

3. Have the enactments of laws led to the shift of moral boundaries, or rather, have the shifts in moral boundaries led to the enactments of laws?

4. As both individuals and society bring up preservation of Constitutional rights issues, whose rights are being legislatively protected, and from whom or what?

5. What sort of legal demands and actions may arise when a person in one camp of the Constitutional rights dichotomy (individual versus society) suddenly finds that he or she is now in the other? 


\section{THEORETICAL FRAMEWORK}

\section{The Meaning of "Law"}

An attempt to understand the relationship between law and society can take at least two different approaches. Law can be viewed as a system in and of itself, containing consistent internal relationships such as the interaction between the law making, law applying and law enforcing activities. Alternatively, law can be viewed as a subsystem of the social structure, one which is intimately linked to all other social institutions which make up a society's total culture. For reasons which will be explained later, the view of law as an integral part of the overall structure of society is utilized in this analysis of the effects of the AIDS epidemic on the structure of law.

Deriving a consensual definition of precisely what the term "law" means is an impossible task. According to Webster's New Collegiate Dictionary (1977), law is defined, in part, as:

1a(1): a binding custom or practice of a community: a rule of conduct or action prescribed or formally recognized as binding or enforced by a controlling authority (2): the whole body of such customs, practices, or rules (3): COMMON LAW b(1): the control brought about by the existence or enforcement of such law (2): the action of laws considered as a means of redressing wrongs; also: LITIGATION (3): the agency of or an agent of established law c: a rule or order that is advisable or obligatory to observe d: something compatible with or enforceable by established law e: CONTROL, AUTHORITY (p. 651).

The context within which the term "law" is used often goes beyond these dictionary definitions by adding other abstract and value-laden concepts. As a consequence, the seemingly straightforward dictionary definition becomes vague and unclear.

Four words frequently used when exploring the "science of law" are identified by Pound (1951, p. 2): justice, rights, law and morals. Each of these 
four words has been used interchangeably and on their own have abstract and often ideological overtones depending on who is doing the defining. There is no universal agreed upon definition of the term "law" as legal scholars use this term.

However, Pound (1951, pp. 48-49) does attempt to limit the myriad definitions of law by identifying what he believes are the three most common meanings or ideas among those who use the term: (1) the legal order, as a regimen of social control which emphasizes the systematic and orderly application of the use of force within a politically organized society; (2) the body of authoritative guides, whether judicial or administrative models or patterns of decision, relied upon in particular by lawyers in guiding conduct; and (3) the judicial and administrative process currently utilized and sometimes referred to as the "judicial process." Thus, law may be generally defined as a social control system within a society which makes use of guidelines and/or relies upon previous actions, yet is amenable to change and modification over time when dealing with novel controversies and causes.

Some modern scholars, in the view of Bohannan (1979, pp. 73-74), attempt to define "law" by identifying three "basic issues" or questions which include: (1) how is law related to the maintenance of social order; (2) what is the nature of the relationship between legal and moral obligation; and (3) what are the social rules of conduct and to what degree are these rules involved with law. Other writers, however, identify sets of attributes which are associated with law, leading Bohannan to portray law as having seven distinguishing characteristics. In this view, law:

... (1) is a complex whole, (2) which always includes social norms that regulate human behavior. These norms are (3) social in character, and they form (4) a complex whole that is "orderly." The order is (5) characteristically coercive and (6) institutionalized. Law has (7) a degree of effectiveness sufficient to maintain itself. (Bohannan 1979, p. 73). 
While the above definitions and attributes do not necessarily contradict each other, they do illustrate the difficulty in finding agreement on the role and responsibility that law has within a society. The role law plays in controlling "moral behavior" and "constitutional rights" is frequently challenged. These challenges frequently center around the controversy over whether laws are enacted to protect the public from the individual, or are they intended to protect the individual from the public? Additionally, they may involve challenges involving classes of individuals as in whose interests are being represented.

The legal system in most if not all countries is considered to be an important institution, critical to the overall functioning of society. While the exact nature and specific influences of legal institutions vary from society to society, the legal system is often relied upon as the ultimate authority and arbiter for resolving disputes between individuals, organizations, and distinctive cultures, and for defining acceptable and unacceptable behavior.

Looking specifically at law as an institution of society, Berger and Luckmann (1967, pp. 75-76) point out that beyond the necessity of roles (characterized by one's own and others' interrelated performances), law:

... is, of course, also represented by legal language, codes of law, theories of jurisprudence and, finally, by the ultimate legitimations of the institution and its norms in ethical, religious, or mythological systems of thought. . . . All these representations, however, derive their continuing significance and even intelligibility from their utilization in human conduct, which here, of course, is conduct typified in the institutional roles of the law.

In this view, not only are roles important in understanding the relationship between law and society, but also the language, legal codes, and jurisprudence interwoven in the norms and values associated with the ethical, religious and/or mythological thought systems of a society. 
Definitions of what constitutes an institution also vary with some being more explicit than others. A social institution according to Bohannan's (1979, p. 74-75) definition, is a group of people who are united, and thus organized, for some purpose; who have the material and technical means of achieving or attempting to reach that purpose; who support a value system, ethics, and beliefs which validate that purpose; and who repeat more or less anticipated activities and events in order to carry out that purpose. He distinguishes a legal institution from other social institutions by adding that the legal institution also serves as a means by which people within a society settle disputes that arise between one and another. In addition, law monitors potential wrongdoings and corrects violations which other social institutions may engage in and which may conflict with the overall good of society.

The legal system is often seen in its idealized form as being a regulatory mechanism which functions to preserve the established values of a particular group of people through monitoring individual or organizational behavior by the imposition or threat of sanctions. It is seen as a codification of the moral values and beliefs which are widely accepted and established within a community or society. Law is seen as the official expression of what is regarded as right or wrong in a society. It also serves as a functional tool by which behavior is regulated and evaluated, along with being a socialization instrument for introducing and instructing new and younger members of a society as to what types of behavior are considered appropriate or inappropriate (Sagarin and Kelly 1981, pp. 21-22).

While law is not always successful in these diverse endeavors, and in fact the enactment of laws often is the result of a compromise between conflicting expectations and beliefs as to what are intrinsic rights between groups and individuals, it has been said: 
What the law has been trying to do is to adjust relations and order conduct so as to give the most effect to the whole scheme of expectations of men in civilized society with a minimum of friction and waste. (Pound 1951, p. 29).

\section{$\underline{\text { Law and Society }}$}

The legal system is a social mechanism which is often thought to provide protection for the individual from the public and at the same time to protect the public from the individual. By imposing rules and regulations on individuals to govern their behavior, society's well-being is being protected. By imposing another set of rules and regulations governing the conduct of social organizations and institutions, the individual is being protected. The intent is that these two objectives mesh so that both individuals and society as a whole are treated as morally and ethically equal.

Many theorists have looked at the complicated yet subtle relationship between society and law. One of the questions often pursued is whether law is a reflection of the nature of a society, or whether society is shaped by law. This is an ongoing debate to which there is no resolution. Classical theorists such as Karl Marx, Max Weber and Emile Durkheim have relied on a conception of uni-directional causal relationship between law and society. This single direction causal relationship includes the belief of some theorists that legal change leads to social change, and of others that social change leads to legal change. Several contemporary theorists such as Philip Selznick, Niklas Luhmann and Edwin Schur, however, have come to view this causal relationship as a developmental process in that the understanding is that law is the law of society and changes with it (Luhmann 1985; Selznick 1968, 1969; Schur 1968). This line of thought promotes the notion that the causal relationship between law and society is interactive, each dependent on the other in a constantly changing and evolving process. 
In order to understand the underlying relationship between law and society as they both respond to the AIDS epidemic, a review of classical and contemporary theoretical approaches is important. While a multitude of theorists have explored the relationship between law and society, the focus here is limited to those works most pertinent to understanding this relationship in the context of the AIDS epidemic. These theorists have explored and expanded upon the two aspects of the causal relationship: uni-directional (from either direction) versus bi-directional. The classical theorists have addressed the phenomenon of increasing complexity of the legal system as a corollary of the increasing complexity of the social order. The contemporary theorists discussed here have built upon earlier theories of law and society, added to them, or branched out with new theories as they take into account technological advances achieved by society unknown and unforeseen by the earlier theorists. Contemporary theorists attempt to include an appreciation of the complexity of the society/law relationship by taking into consideration the way and manner in which the legal order of society in modern times has developed. Throughout many of the more recent writings, the term "complexity" is used to reflect the numerous factors which have an impact on the law (e.g. access to high-tech information or knowledge, networking capabilities, transportation, mass media, and telecommunications). As will become apparent, recognition of the complexity of the processes involved in the genesis of law is crucial to an understanding of the formal response to the AIDS epidemic.

\section{Classical Approach}

The relationship between society and law was the frequent target of many theorists in the mid-1800's who were trying to explain the impact various institutions, mores, and values of society had on human behavior. These theorists 
were attempting to explain not only the "why" of previous human conduct, but to anticipate future society given the conditions of their times. Theorists such as Karl Marx, Max Weber, Emile Durkheim and Oliver Wendell Holmes all explored the relationship between law and society and each made important contributions to the common stock of knowledge relied on by theorists today.

In his analysis of the way Karl Marx approached the relationship between law and society, Phillips (1980, pp. 186-87) points out that in many of Marx's early writings he appeared to favor the uni-directional view wherein "the 'legal nature of things' cannot be regulated by law but rather law must be regulated by the legal nature of things." During a speech given in his own defense at the "Trial of the Rhineland District Committee of Democrats," Marx stated:

However, society does not depend on the law. That is a legal fiction. The law depends rather on society, it must be an expression of society's communal interests and needs, arising from the material mode of production, and not the arbitrary expression of will of the single individual. (Phillips 1980, p. 187).

During this trial, Marx wanted to illustrate law as being passive and society as active (Phillips 1980, p. 188). Phillips argues that while he may have hinted at relative autonomy of law from society in many of his other works, Marx never expanded on or developed this idea. In fact, much of what is concluded from Marx's works on the relationship between law and society is that modifications in de jure social rules and regulations are merely reflections of modifications in a society's economic base (Phillips 1980, pp. 199-201).

Max Weber, defined many concepts, including the concept of law, in Economy and Society (Rheinstein 1954, pp. xxxviii-xliii). Included in Weber's conceptual definition of domination are three "pure types" of legitimate domination: (a) legal domination; (b) traditional domination; and (c) charismatic domination. As Rheinstein (1954, p. xlvii) points out, Weber was concerned with the process of 
legal thought in general rather than with a specific aspect of judicial thought. For Weber, laws were orders which established "a set of ought ideas which are held in the minds of certain people" (Rheinstein 1954, p. lxvii). The relationship between law and society, then, is found by looking at various aspects of law making and law finding and what interactions occur between individuals in a society.

In her analysis of Weber's Law and Economy in Society, Simon (1968, pp. 6-7) points out that Weber's most useful definition of law is "a system of norms which are guaranteed by legal coercion." She concludes that Weber, in his use of the term "legal coercion," meant that the law embodies not only physical coercion and/or violence, but that it also includes all of the coercive mechanisms which are represented by the court, police, administrative bodies, and organizations. When a member of a given society is said to have a "right," Weber defines this "right" to mean "He has a chance, factually guaranteed to him by the consensually accepted interpretation of a legal norm, of invoking in favor of his ideal or material interests the aid of a 'coercive apparatus' which is in special readiness for this purpose" (Simon 1968, p. 7).

"Coercive apparatus" or legal coercion for the purpose of norm enforcement, in Weber's terms, is translated by Selznick (1979) to mean that a legal norm is known by the probability that it will be enforced through the actions of a specialized organization. Selznick credits Weber with providing an operational definition of law that is meant to exclude all value judgments in determining what is and what is not to be considered law. He also points out that while Weber emphasized coercion, legal action does not solely depend on physical force. Thus, while physical coercion may play an important role in the understanding of the relationship between law and society, it is not essential. However, the threat of physical coercion may be an important consideration. Weber's definition of legal norms can therefore be applied 
to other types of laws which may apply only to individuals who voluntarily belong to an organized entity (e.g. ecclesiastical law, or the laws created by corporate groups which are binding on all its own members) (Selznick 1979, p. 59).

One of Emile Durkheim's major goals was that of attempting to understand the relationship between the individual and society. To that end he paid particular attention to what he termed social solidarity. He attempted to explain what it is that holds individuals together to form a functioning society. His concept of collective conscience, seen in a society's norms or rules of conduct and sanctions imposed when these norms are violated, included established laws. The legal code (laws) thus reflects the underlying character of a society, its institutional structure, and thus the form of social solidarity ascribed to. As a society shifts from mechanical solidarity (uniformity in beliefs and social integration with other members of society) to organic solidarity (pluralistic beliefs and interdependence with other members of society resulting from a division of labor), the laws likewise change: from repressive to restitutive in nature.

One point on which Durkheim was adamant was that scientific methods should be employed when studying social facts which arise from social phenomena. Laws thus were seen as creating an external index by which the internal or moral facts which partially comprise the organizational structure of society can be examined. As a result, one technique he used was to look at legal codes of various societies in order to ascertain the social nature evidenced in those societies.

Laws that integrate a number of homogeneous attitudes and practices of a group of individuals are often classified as repressive and are most likely to be found in societies demonstrating mechanical solidarity. Restitutive laws which seek reimbursement for loss, damage or injury, and which do not necessarily seek also to impose penalties for a particular behavior, are associated with organic solidarity. 
In looking at the structure of societal laws, Durkheim (1933) created a classification or index for empirically analyzing social solidarity. In The Division of Labor in Society he looked at the role law plays in regulating social relations, especially as a society shifts from mechanical to organic solidarity. As a result of alterations in the division of labor brought about by technological advances and adaptations, the body of law undergoes a corresponding restructuring and refocusing.

Moral boundaries of a mechanical society are more easily defined and maintained through the use of repressive laws wherein every societal member has no doubt about what constitutes crime and what the response to such normative violation should be. Remedial actions would often be to impose penalties including either payment or deprivation of some kind appropriately linked to the nature of the crime. The moral boundaries of an organic society which incorporate restitutive laws focusing on a return of things to their previous state, however, are more difficult and complex in definition and maintenance.

According to Durkheim, the notion of interacting parts (individuals) working together for the well-being of the totality (society), carries with it the concept of the "state" to act as an arbiter between the individual and society (Jones 1986, p. 57) indicates that Durkheim implied in The Division of Labor in Society that the state is "merely an instrument whose authority reflects the disposition of the conscience collective" (emphasis in original).

To Durkheim, then, the state essentially represents the interests of the population as evidenced in a range of norms, including the law. Further, he suggests that the identification of deviant behavior may, in fact, be a necessary factor for continued social functioning in that it allows people who share a particular posture to collectively display their anger and wrath. As people come together to 
express their outrage over the violation of a rule governing a particular form of behavior, they, in fact, develop or reinforce a bond of social solidarity thereby providing a "social glue" which keeps intact the moral boundaries of a society (Erickson 1966, p. 4). As we shall see, this paradox of order appears to be developing into a dilemma of law dealing with personal rights versus public protection in the "Age of AIDS."

Oliver Wendell Holmes also examined the relationship between law and society. In an address given at Boston University School of Law on January 8, 1897 , he delivered a speech regarding the relevance of law and how much of it is drawn from the morals of individuals within a society. The following are excerpts from that speech:

The law is the witness and external deposit of our moral life. Its history is the history of the moral development of the race. The practice of it, in spite of popular jests, tends to make good citizens and good men. When I emphasize the difference between law and morals I do so with reference to a single end, that of learning and understanding the law.

The law is full of phraseology drawn from morals, and by the mere force of language continually invites us to pass from one domain to the other without perceiving it, as we are sure to do unless we have the boundary constantly before our minds. The law talks about rights, and duties, and malice, and intent, and negligence, and so forth, and nothing is easier, or, I may say, more common in legal reasoning, than to take these works in their moral sense, at some stage of the argument, and so to drop into fallacy. (Holmes 1968, pp. 19-20).

Holmes also pointed out that laws enacted at one point in time are not necessarily the laws that will be logical and appropriate at another.

The language of judicial decision is mainly the language of logic. . . . Behind the logical form lies a judgment as to the relative worth and importance of competing legislative grounds .... . You can give any conclusion a logical form. You can always imply a condition in a contract. But why do you imply it? It is because of some belief as to the practice of the community or of a class, or because of some 
opinion as to policy, or, in short, because of some attitude of yours upon a matter not capable of exact quantitative measurement, and therefore not capable of founding exact logical conclusions. ... We do not realize how large a part of our law is open to reconsideration upon a slight change in the habit of the public mind. (Holmes 1968, p. 26).

Thus, in the view of Holmes and of others of a like mind, as attitudes and beliefs regarding acceptable and unacceptable practices within a community shift, laws are likewise susceptible to these changes so that they are in line with the moral beliefs and practices of society.

Summary. In summary, these classical theorists all contributed to a perspective to be utilized in the present exploration of legal codes and court decisions in response to the AIDS epidemic in the United States. Marx presents the idea that the changes in de jure social rules are reflective of society's economic base. This notion of society's economic base can also be applied to the question of what kind of legislative activity has occurred in response to AIDS by particular special interest groups or individuals who are in positions of power or influence within American society.

Weber offers the definition that laws are "a system of norms which are guaranteed by legal coercion." This definition is particularly useful when looking at the language contained in the multitude of proposed and enacted laws that have emerged dealing with AIDS-related issues since 1980.

Durkheim's sense of restitutive law appears relevant to a focus on current legal codes and court decisions in response to the AIDS epidemic in the United States. Durkheim referred to this type of society as being organic since the specialization brought about by the division of labor requires individuals to work in harmony for the overall good of the whole (society). The paradox that results in an organic society is the assumption that individuals are able to exercise autonomy or 
free will to act, while at the same time the division of labor which affords them this ability also makes them more dependent upon society for other social needs.

Finally, Holmes explains that the relevance of law is drawn from the morals of individuals in society and that laws are bound to change over time. Thus, with the introduction of AIDS, it was obvious that laws in place prior to 1980 dealing with communicable diseases were unable to fully address the dualism of individual and societal rights, and it was logical and inevitable that the old laws would be challenged and replaced with new ones.

\section{Contemporary Approach}

Sociology is indebted to the classical theorists for establishing the foundation upon which contemporary theorists have based further explorations of the relationship between law and society. While some contemporary theorists find fault with earlier theories and develop their own viewpoints, others such as Kai Erickson, Philip Selznick, and Niklas Luhmann build upon earlier ideas after taking into consideration the process of historical evolution. By looking at how others such as Hans Kelsen, Eugen Ehrlich, Thomas Cowan, Laura Nader and David Serber view the relationship between law and society, a better understanding of legal activity to date at this stage of the AIDS epidemic is possible.

In Wayward Puritans Kai Erickson (1966), relies on Durkheim's theorizing in an attempt to look specifically at social boundaries and what place the identification of rule breaking has in defining or maintaining a boundary. Additionally, Erickson's work supports Durkheim's view that responses to violations of highly respected rules of conduct within a community result in the development of tighter bonds of solidarity or reaffirmation of the community's values as outraged citizens gather together (figuratively or literally) to express their anger. 
In contemporary America, individuals can be immediately notified of actual or putative deviance through various branches of the media. The arena in which citizens come together to express their feelings often is the courtroom. The jury ideally represents a cross-section of members within a particular society to stand in judgment of one of their peers. The "collective conscience" of a society is thus reinforced as deviance is defined as that which "makes people more alert to the interests they share in common and draws attention to those values" (Erickson 1966, p. 4).

A society's control agencies, as pointed out by Erickson (1966, pp. 24-25), are geared towards stabilizing, eliminating, or keeping deviance within some defined boundary rather than trying to entirely eliminate the deviant behavior. A society will invoke "emergency measures" when the volume of deviance threatens to grow beyond some defined bounds of what is deemed normal, but otherwise will not react if the volume of deviance stays within these defined limits. Laws are one of the "emergency measures" enlisted by society to either redefine the acceptable deviance/conformity boundary, or to help contain any increase in the deviant behavior.

The importance of laws is addressed by Selznick (1979). Laws are secondary in nature in the sense that they obtain their legitimacy in terms of some other more primary reference point, which according to Selznick (1979) is a society's moral order:

The distinctively legal emerges with the development of "secondary rules," that is, rules of authoritative determination. These rules, selectively applied, raise up the unofficial norms and give them a legal status. 
The elementary legal act is this appeal from an asserted rule, however coercively enforced, to a justifying rule. This presumes at least a dim awareness that some reason lies behind the impulse to conform; furthermore this reason is founded not in conscience, habit, or fear alone but rather in the decision to uphold an authoritative order. The rule of legal recognition may be quite blunt and crude: The law is what the king or priest says it is. But this initial reference of a historically given social norm to a more general ground of obligation breeds the complex elaboration of authoritative rules that marks a developed legal order. (Selznick 1979, p. 52) (emphasis in original).

Further Selznick (1968) points out that while there are legal scholars who believe in and support the idea of legal autonomy from the social structure, in the United States, at least, there is great support and little need to argue for a sociological conception that there is general interdependence between law and society and that legal rules will be tested through their practical effects.

Little will be gained from further demonstrations that law serves social interests and that these interests, in turn, reflect the changing structure of society. (Selznick 1968, pp. 190-91).

Like Selznick, Luhmann (1985) believes that the relationship between society and law is so intimate that the foundation of each is dependent on the other. Luhmann does not view law as merely the result of one set of factors exerting influence over another set. Rather, he finds that there is a necessary inner connection between law and all kinds of social life.

Law as structure and society as social system must therefore be seen and researched in a relation of mutual interdependence. This connection has, apart from the factual, also a temporal aspect and therefore leads to an evolutionary theory of society and law. (Luhmann 1985, p. 7).

Luhmann (1985, p. 104) points out that the structure of a system is mainly responsible for its complexity and is linked to the potential range of environmental conditions it can accommodate. He comments: 
Society is that social system whose structure regulates the ultimate and basic reductions to which other social systems can be attached. It transforms indeterminate into determinate, or for other systems determinable, complexity. . . . The social structure of society has therefore a function of easing the load on the social systems which are formed within society. (Luhmann 1985, p. 104).

Law, in this view, plays an important role in providing the structure by which society as a system is organized.

However, law is essential as structure, because people cannot orient themselves toward others or expect their expectations without the congruent generalisation of behavioural expectations. This structure has to be institutionalised at the level of society itself, because it is only here that we can build beyond preconditions and create those establishments which domesticate the environment for other social systems. It therefore changes with the evolution of societal complexity. (Luhmann 1985, p. 105)

In exploring the relationship between law and society, Luhmann (1985, p. 243) states that in order for legal changes within society to be successful, individuals must be able to effectively adapt to expectations and norms. Not only is there an interdependent relationship between law and society, but there is a direct relationship between law and all other social systems within society.

Laws, according to Kelsen (1967) exhibit various characteristics. He stipulates that laws are (1) orders of human behavior, and that they are (2) coercive orders. By this he means that laws reflect the attitudes of the social majority toward certain events which may be regarded as undesirable because they are detrimental to society. Thus, by decreeing negative sanctions upon the performer of specific behaviors, such as deprivation of life, health, liberty or economic resources, the opposite behavior is reinforced as not only acceptable but preferable.

As defined by Ehrlich ([1936] 1962, p. xix) laws are compulsory orders. Sanctions are not necessarily attached to all laws, and in fact, many laws are enacted without any sanctions, negative or positive, attached to them. For example, laws indicating when city street lights are to be turned on do not describe sanctions for 
deviance. Laws are, however, orders to be followed by the members of a given society. Laws are not only the rules of conduct by which individuals regulate their behavior, but are also rules which define the behavior in which they ought to engage (Ehrlich [1936] 1962, p. 11). As Friedmann (1964, pp. 20-21) points out, Ehrlich also places a great deal of emphasis on the "living law" of people which is based on social behavior rather than on state proscribed compulsive norms or laws. Social norms (illustrated by behavior within society), whether involving matters such as religion, family life or commercial relations, become "living law" even if they are not recognized, outlined or defined by the state. Compulsive state norms or laws are specifically related to institutions to which the state is directly linked, such as military organizations, taxation, and police administration. Thus, the main body of law develops from the social life of the people, while a much smaller sphere of state norms or laws are created for purposes of organization and protection.

Laws, however, are not always clearly defined as to whether they are in place to ameliorate social dysfunctions or to maintain a desired level of social order. Negative sanctions imposed on individuals as a result of breaches of specific legal codes are more easily identified than are laws which encourage and maintain a particular level of social order. A law may settle conflicts through adjudication, mediation, arbitration, or other intervention methods; its sole purpose may be punitive; it may prevent or deter breaches of the law; it may focus on maintaining order in institutions such as jurisprudence, politics and economics; or it may accomplish all of these goals. It is not always clear by reviewing the legal code, however, what a particular society is intending to emphasize (Nader 1968, pp. 222-23).

In looking at modern society in relation to law, Cowan (1980) proffers his view that instead of merely looking at individual interests or at interests associated 
with society as a whole, another category defined as "group interests" would be more appropriate given the pluralistic nature of most 20 th century societies. He refers to "group interests" as including sociologically defined "secondary groups" which may include, unions, clubs, boards, councils, associations, societies, professions, taxpayers, consumers, and even groups referred to as "interested parties." In this conceptualization, the group's interest falls on a continuum somewhere between the uniquely individual and the totally societal interest of its members.

Groups make demands for themselves and resist demands from other groups, individuals or society as a whole (Cowan 1980). If members of groups organize themselves and pursue a specific form of action towards some defined goal, their collective efforts are more efficient and successful in bringing about changes or modifications in the existing social order (e.g. in laws or rules of conduct), than if they attempted to do so on their own. Group efforts may, although by no means necessarily do, lead to changes which serve to enhance the overall well-being of society. Special interest groups, as they are often referred to, frequently persuade governmental representatives to introduce laws representing their own values and interests in hopes that they will be enacted. As Quinney $(1970$, p. 12) points out "Groups with the power to gain access to the decision-making process also inevitably control the lives of others. The influence of special interest groups has been illustrated over and over again as American society has been forced to deal with both victims and nonvictims of AIDS. For example, parents rallied together and initially were successful in keeping the human immunodeficiency virus (HIV) positive or active-AIDS children from attending school. More recently, several special interest groups have forced the medical profession and federal, state and 
local governments to deal with infected health care workers and the rights of their patients.

Other theorists see the use of law as an attempt by those in positions of authority to exercise power to shape the legal structure to best meet and serve their own narrow interests. Nader and Serber (1980) point out that national law is a mechanism in addition to a process which is frequently used to distribute or centralize power, or it may be employed to legitimate and maintain power groups. While myriad state and federal agencies have been created to balance out power discrepancies by protecting the public's interests through regulations and detailed monitoring of various aspects of big business, they often operate with de jure rather than de facto authority.

Laws, as pointed out by Chambliss and Seidman (1971, pp. 7-8) are a particular order of norms which define how people or collectives ought to act. Some laws are directed to everyone (e.g. the prohibition of homicide), while others are directed to specific populations (e.g. automobile drivers), while yet others are directed to specific positions (e.g. duties particular to the President of the United States). Most of these laws outline negative sanctions to be imposed upon violators. In a centralized State, these sanctions are often initiated and imposed by State officials (e.g. police or prosecutor), and punishment is often carried out by other State officials (e.g. corrections officers). This power by the State, in the form of laws, to "induce" or "coerce" individuals to behave in a particular manner is not always successful. When laws are violated, the punishment as defined by these laws is imposed. The legal system, as Chambliss and Seidman (1971) define it, . . . is a system by which one part of the population uses State power to coerce another segment. It is a system for the exercise of State power. (p. 10). 
In addition to the power of the State, Chambliss and Seidman (1971) believe that the extent of stratification in a society is an important factor in understanding the types of laws created and the sanctions to be imposed for violation.

The more economically stratified a society becomes, the more it becomes necessary for the dominant groups in the society to enforce through coercion the norms of conduct which guarantee their supremacy. It would seem probable that the more the social structure creates and enforces inequality, the more the life experiences of various groups differ and consequently the norms internalized by people in different strata can be expected to vary as well. (Chambliss and Seidman 1971, pp. 33-34).

In his study of deviance and social control, Akers (1985) identifies three interrelated phases of one process:

... (1) the establishment of social norms of right, correct, or expected behavior; (2) deviation from or violation of those expectations by groups and individuals in society; and (3) the reactions of other groups, individuals, and control agencies to such deviation. (p. 5) (emphasis in original).

These three phases can be easily applied to the AIDS epidemic within the framework of moral boundary creation and maintenance through the use of laws and statutes. For example, prior to the 1980's there existed sets of social norms in the form of laws which, with variable clarity, detailed moral boundaries or consensus within society as to what was defined as right and wrong. Many of these norms or laws were violated or deviated from as individuals were diagnosed as having the HIV or AIDS. The result has been evidenced by the reactions of various groups and individuals to these deviations in the form of redefining existing values and mores, along with revising laws reflecting these new definitions and outlining the manner in which they will be enforced (Akers 1985, p. 5) points out that one of the key elements in defining what constitutes right and wrong, standards of conduct, and rules and regulations is social interaction. 
Summary. In summary, contemporary theorists have contributed an increased understanding of the relationship between law and society which proves to be useful in looking at the legislative activity which has occurred in the United States in response to the AIDS epidemic. Erickson looks specifically at social boundaries and the place rule breaking has in defining or maintaining a boundary. This viewpoint is valuable in trying to understand why there was very little initial legislative response to the AIDS epidemic and only after it was determined that seemingly moral individuals could also become infected, in addition to the fact that the number of individuals directly affected rapidly increased, that there was governmental concern.

Both Selznick and Luhmann point out that the relationship between society and law is so interdependent that rather than a change in society leading to change in laws, or a change in laws leading to a change in society, law and society change with each other. Given the short time frame since AIDS became recognized as a communicable disease and the volume of legislative activity that has been generated by federal, state and local governmental agencies, and perhaps influenced by private industries, this approach is useful to understand the nature of the relationship between law and society in response to the AIDS epidemic.

In their definitions of law, Kelsen and Ehrlich present a view that laws decree negative sanctions or compulsory orders to keep individuals within a desired or acceptable moral boundary. This is particularly useful when the content of the many proposed and enacted laws is examined. Many of these laws prohibit certain conduct, require that specific procedures be followed, or monitor an individual's activities and behaviors.

Cowan and Quinney each look at groups and how their organized efforts are often more successful than individual efforts in bringing about changes in the social 
order. This is certainly helpful when looking at some of the laws currently being enacted relating to the HIV and AIDS patients. In particular, the laws pertaining to the health care profession have been greatly impacted during the last 10 years.

Nader and Serber, and Chambliss and Seidman present the position that in a centralized State where key individuals or groups are in positions of authority, one part of society is able to keep another subordinate to the dominant group's values and interests. It can easily be argued that much of the proposed and recently passed legislation dealing with the HIV and AIDS is a direct consequence of particular groups in positions of power and authority.

Finally, Akers discusses how efforts to answer questions regarding social labels of "deviance" center around three interrelated phases of one process. These phases include: (1) the establishment of social norms of correct or expected behavior; (2) deviation from those expectations; and (3) reactions of others to such deviation. Societal response to the AIDS epidemic readily fit into Akers three phases. Initially there was an established set of social norms (existing laws). Individuals infected with the HIV and AIDS were seen as deviating from these norms, and the subsequent reactions can be found not only in the modification of existing laws and introduction of new ones, but also in the way social institutions are now interacting.

The theories of law relied on today are many. There is no metatheory of law. Consideration of the theories helps to understand the uneven, unpredictable, and often inconsistent manner in which the legal system in the United States has responded to the AIDS epidemic. From a legal standpoint, the AIDS epidemic is a new and specific social phenomenon which is in the process of being dealt with. While the legal community has addressed contagious diseases in the past, the AIDS epidemic brings to the forefront many civil rights issues previously unaddressed. 


\section{MORAL BOUNDARIES}

The concept "moral boundaries" is abstract and can be defined any number of ways. For purposes of this thesis, moral boundaries are evidenced by the laws of a given society. These laws reflect a codification of moral principles, values and beliefs that are widely accepted and established within society. Morals and values are the underpinnings of the legal structure and the laws that are created and abided by a majority of societal members attempt to preserve and protect these common values. The precise nature of the moral boundaries of different societies differs to a greater or lesser extent, depending upon the degree of similarity of the cultures of various societies. In addition, the content within these borders is never permanent and is likely to fluctuate with time.

In addition to establishing a set of rules by which individuals are able to regulate and evaluate others' behavior, laws serve to socialize new and younger members of society as to the acceptable and unacceptable beliefs, social expectations, and cultural practices. While the substance contained within moral boundaries may change abruptly and radically, most often it alters slowly and in a piecemeal fashion.

During the last decade moral boundaries of American society have been severely challenged. This confrontation has produced abrupt, drastic, radical and dramatic alterations in the content of these boundaries as defined by laws. These modifications in moral boundaries are a result of how American society has reacted to the AIDS epidemic.

In order to understand how and why this change in American moral boundaries pertaining to AIDS is occurring, some background from the last decade 
is appropriate. The following is a brief history of AIDS and how it has evolved from an undiagnosed "mysterious" illness to its present pandemic status.

\section{BACKGROUND}

\section{AIDS, the Disease}

In June of 1981, workers at the Centers for Disease Control (CDC), the federal epidemiology agency located in Atlanta, Georgia, began noticing an increased number of reports indicating diagnoses of individuals with a rare form of pneumonia termed Pneumocystis carinii pneumonia, and others with a form of skin cancer known as Kaposi's sarcoma. The first official announcement of concern over what many thought to be a "new" illness was published on June 5, 1981 by the CDC in its weekly bulletin, the Morbidity and Mortality Weekly Report (MMWR). The article reported and described five severe pneumonia cases observed between October 1980 and May 1981 in three Los Angeles hospitals. The initial victims exhibited common identifiable characteristics: they were all relatively young (29 to 36 years old) gay men, and all had pneumonia attributable to Pneumocystis carinii. The MMWR report not only noted the homosexual lifestyle of these five men, but even emphasized it. The report suggested that there was "an association between some aspect of a homosexual lifestyle or disease acquired through sexual contact and Pneumocystis pneumonia in this population." (CDC 1981, p. 251). The presumption of a predisposition based on the sexual behaviors of the patients who showed signs of immune dysfunction was rather broad given the small sample size.

While these atypical forms of pneumonia and cancer were being reported in Los Angeles, they were likewise being identified in New York and San Francisco hospitals and medical centers. As the number of cases involving individuals diagnosed with these unusual illnesses began to increase, researchers looked beyond 
the specific diagnoses of the individual patients to identify any common elements. As a result of these efforts researchers identified a number of similar personal characteristics and lifestyle behaviors that these patients shared. Physicians also began to contact health care providers in various medical institutions locally and across the United States to exchange notes in an attempt to determine if others were encountering similar patterns in the unusual illnesses and the personal histories of the patients. At that time, concerns about this new development in the medical field were mainly contained in the professional forum.

On July 4, 1981, MMWR published a second report entitled "Kaposi's Sarcoma and Pneumocystis Pneumonia Among Homosexual Men -- New York City and California." That report discussed and analyzed the ages, ethnic backgrounds, sexual orientation (all were homosexual), and specific types of Kaposi's sarcoma each patient had. Even at that early stage of the AIDS epidemic, the media began to notice the increasing number of individuals with these curious and often rare ailments. On July 3, 1981, the day prior to formal publication date of the July 4, 1981 MMWR, Lawrence Altman (the medical correspondent for the New York Times), published a summary of the July 4, 1981 CDC report, and included two interviews with professionals discussing the new and mysterious ailment which seemed to be restricted to a specific population. The story was entitled "Rare Cancer Seen in 41 Homosexuals" (Grmek 1990, p. 8). This article was to be only the first of myriad articles to follow aimed at informing the nonprofessional public. These articles not only educated the public about a new and mysterious illness, but also brought forth a rash of questions and concerns which the medical profession could not answer.

Before long, other cases were added to the increasing list of the mysterious diagnoses. Personal histories were categorized and cross-referenced in an attempt to 
find behavioral patterns and characteristics in common among the victims. It appeared that the initial cases were located in cities known for their large gay communities, specifically Los Angeles, San Francisco and New York. Later, other cities with either large gay communities and/or coastal locations such that they were ports of entry into the continental United States (such as those in Florida and Washington D.C.) would also capture the attention of those pondering this new ailment.

At first, this unidentified and obscure ailment was known as the "gay cancer," "gay pneumonia," and the "gay plague" in that it appeared to only affect homosexual men (Shilts 1988). It was sometimes referred to as GRID (Gay- Related Immune Deficiency). The English medical journal The Lancet proposed to call the new disease the "gay compromise syndrome." Officially, however, the disease remained nameless until the summer of 1982 when its official name "Acquired Immune Deficiency Syndrome" and easily remembered acronym "AIDS" was decided upon during a CDC staff meeting. By this same time proof of the viral etiology was available, and cases of the disease were identified and verified on each continent (Grmek 1990, pp. 10-13).

Although the etiology of AIDS is considered understood by the medical profession, questions still remain unanswered about this disease. Within the medical arena itself, there has emerged a controversy involving the relationship between the HIV and AIDS. For example, there is currently a heated debate as to whether the relationship between the HIV and AIDS is correlational rather than causal (Duesberg 1991; National Academy of Sciences 1991). Given the fact that the medical profession, the institution society looks to for answers regarding mystical diseases, is unable to clearly define, let alone, cure this ailment, it is not hard to find evidence of fear, panic and discriminatory behavior frequently occurring within the larger 
society. Much of this fear and panic is a result of the complex etiology of AIDS and the inability of the medical profession to provide a cure.

Traditionally, society has relied on medicine to provide answers for new medical problems. During the nineteenth century, the prestige of the medical profession grew tremendously. The consultation and the examination room became a sacred setting in which conversations were considered confidential and private. This placed the physician in the powerful position of being able to exercise immense moral and physical control over the patient (Gilbert 1975). During the latter part of the nineteenth century, disease boundaries were expanded to include behavior patterns which in earlier generations might have been dismissed as perverse or criminal. Most obvious was the manner in which deviance was increasingly being defined as a consequence of a disease process and therefore the physicians' responsibility to treat and cure. For example, alcoholism, drug addiction, and homosexuality became possible medical diagnoses of illness rather than behaviors performed by individual choice (Conrad and Schneider 1980). Also occurring at the turn of the century was the medical profession's increased involvement in public health. This was a relatively new area for medical practitioners and most likely resulted from the expansion of responsibility they were experiencing. As a result, interventionist activity was beginning to influence policy guidelines (Rosenberg 1988).

Since the 1960's, however, sociologists and social critics have criticized the use of these arbitrary medical labels and the subsequent stigmatizing of groups defined as deviant. Sexual deviance, various forms of addiction and even criminality have been categorized by the medical profession as being associated with some sort of illness (Rosenberg 1988). The association of a mysterious new affliction (known later as AIDS) with a form of deviant behavior (e.g. the sexual 
behaviors of individuals with this medical ailment), focused the attention of society on the medical profession for instant and accurate answers.

Involvement by physicians in particular medical procedures has also brought about a change in public perception of the character of certain acts. For example, until recently, artificial insemination was considered immoral, sinful and adulterous. However, with time, physician involvement and in particular specialization by doctors in the study and treatment of infertility, social attitude towards artificial means of achieving pregnancy have changed to one of general social acceptance (Wikler and Wikler 1991). However, as new reproductive technologies emerge, such as those currently involving surrogacy alternatives, they face public scrutiny and possibly demoralism prior to social acceptance.

While there is mistrust of the medical profession's ability to provide all of the answers, there is also a great deal of faith in it by many laypersons. The medical laboratory is the place where cures are found that make disease and illness go away and prevent their reoccurrence. This belief was also held by most laypersons regarding earlier diseases such as the plague, diphtheria, cholera and tuberculosis which killed large numbers of people. The reality, however, is that behaviors which placed individuals in high risk categories of contracting these earlier contagious diseases were modified through improved sanitation and nutrition before medicine provided vaccines and treatment (McKinlay and McKinlay 1981, pp. 12-30). However, the layperson still looks to the medical profession for answers, and, in particular, for solutions to this new medical mystery.

Much of the mystery surrounding AIDS lies in its etiology. Before a cure can be found, an understanding of the disease is necessary. To date, while scientists believe they understand the etiology of AIDS, a cure, vaccine or standard course of treatment has yet to be determined and agreed upon. 
AIDS and the medical conditions associated with it are caused by the HIV, the human immunodeficiency virus. Normally an individual's own body provides protection from viruses and other foreign invaders through a process known as the immune response. Antibodies in the blood of an individual with the HIV increasingly become unable to attack and destroy invading viruses, leaving the individual susceptible to opportunistic bacterial, fungal or viral infections, or various forms of cancer. One of the things that makes AIDS so mysterious and threatening is the fact that even before an individual physically demonstrates any symptoms of the HIV, he or she may be carrying the virus and be capable of transmitting it to others. Blood tests are available which determine whether or not an individual is infected with the AIDS virus by analyzing critical numbers and ratios of specific white blood cells. However, unless physical symptoms are evident, most people do not make use of these tests because they are unaware that they may be carriers capable of transmitting the disease to others (Perdew 1990).

Adding to the fear and misunderstanding of AIDS as a disease is the frequent use of the word "exchange" when discussing modes of transmission. For example, its recurrent use appears in literature as "HIV is transmitted through . . . the exchange of semen or blood." (McKenzie 1991, p. 8). This is not exactly accurate, especially in cases where the HIV is spread through blood or organ transfusion or heterosexual intercourse. Exchange is defined by Webster's New Collegiate Dictionary (1977) as "2b: reciprocal giving and receiving." The fact that the medical professionals, the media and laypersons use the word "exchange" with its reciprocal definition instead of words such as "injection," "receipt," or "transfusion" to indicate the directional flow of the virus only compounds the confusion surrounding how the HIV is contracted and who is at risk of becoming infected through various forms of social behavior. 
Once the virus enters the body, subsequent infection is inevitable. There are no drugs to destroy it, there are no lifestyle behaviors to eradicate, and there are no physical or mental exercises to eliminate it. However, it may take anywhere from several weeks to several months before an individual tests seropositive for the HIV. While the process of seroconversion (going from seronegative wherein a person's blood serum shows no evidence of the HIV infection to seropositive wherein blood serum does) usually takes between 6 to 12 weeks, the virus has been known to remain latent for up to one year (CDC 1987; Bartlett 1988). Even though individuals may test negative for the HIV, if they are carrying the virus, they are capable of transmitting it to others through any of the known transmission mediums (e.g. blood, semen) or means (e.g. infected mother to fetus, mother to baby through breast milk). This latency period, the "not knowing" period, has given rise to concerns by individuals involved in invasive surgeries, where blood transfusions have been utilized, or in work-related accidents involving infected blood or semen. Needle pricks and cuts incurred by health care workers while dealing with infected patients, as well as involvement in invasive procedures performed by infected health care workers on uninfected patients are of concern to patients and healthcare workers alike. Because of the length of the latency period before testing seropositive, lifestyle behaviors may be modified at great emotional and sometimes personal expense after an uninfected individual learns he or she has been directly exposed to contaminated body fluid.

However, if an individual has no reason to believe he or she has been exposed to the HIV, and because there are often no physical symptoms indicative of any health problems, it is believed that affected individuals are likely to engage in one or more behaviors which have been identified as transmitting the HIV long before they have knowledge of their medical condition. This is particularly true 
during the incubation period. Perdew (1990) defines the incubation period as the time between infection of the individual (when the virus first enters the blood) and the time when a diagnosis of an HIV-related condition or AIDS is made. As indicated above, this may be anywhere from several weeks to a year.

The early stage of AIDS is commonly indicated by relatively mild symptoms such as fatigue, fever, night sweats, unexplained weight loss, joint and muscle aches, occasional sore throat, and chronic diarrhea. These symptoms are sometimes referred to as the primary infection syndrome. One of the more telling signs for early diagnosis is persistent swelling or enlargement of the lymph nodes. These symptoms are frequently thought to be flu-like and often victims do not recognize them as anything else. At this point, the victim may appear to recover and reach a plateau even though a blood test would indicate seropositive status. At this stage, an infected individual may feel, look, and act as those uninfected with the HIV. This period is generally termed latency as the virus remains inactive in the infected cells. It is thought that this latency period can last up to 10 years, although it usually ends much sooner. In that research has been conducted on AIDS victims for only a little over 10 years, the full course and direction AIDS may take are unknown. These are some of the many questions still to be answered within the medical arena. Once the latency period ends, an individual is termed as being in the active stage of AIDS, confirmed by one or more of a number of fatal diseases. The quality of life these individuals experience deteriorates rapidly, frequently accompanied by prolonged and excruciating pain and suffering until death.

Some of the more common opportunistic diseases (as identified by the CDC) diagnosed in the HIV positive and AIDS patients include: (1) Candidiasis Esophagitis, a yeast-like fungus which affects the esophagus; (2) Cytomegalovirus (CMV), a common herpes virus which causes few problems in individuals with 
healthy immune systems, but in AIDS patients may cause blindness, pneumonia, intestinal inflammation and inflammation and ulceration of the esophagus; (3) Mycobacterioses, the bacteria responsible for both classic and atypical tuberculosis; (4) Kaposi's sarcoma, an uncommon malignant tumor that can kill its victim by directly attacking vital organs; (5) Pneumocystis carinii pneumonia which affects the lungs of patient with AIDS; (6) Toxoplasmosis, which affects the central nervous system; (7) Cryptococcosis, which very often causes meningitis, but has also been noticed to affect the lungs and other organs as well; and (8) Cryptosporidiosis, which causes severe diarrhea, leaving the patient extremely dehydrated and malnourished (Perdew 1990, pp. 14-16).

AIDS is most often fatal within two to three years of diagnosis, although the length of survival varies depending upon the specific infections to which an individual has succumbed. In addition, the age, sex and ethnic background of the patient are factors which have been found to influence mortality rates (Perdew 1990).

Three categories frequently used by the media and press to refer to individuals with AIDS-related infections include: (1) the HIV infection (without symptoms); (2) AIDS-related complex (ARC); and (3) AIDS (the disease). While the ARC category is considered a standard term, it lacks a common and accepted definition, and in fact, is not used by the CDC. As pointed out by Perdew (1990), however, it is a term understood by the public to include individuals infected with the HIV who exhibit symptoms, but in whom AIDS has not been diagnosed. While frequently used to differentiate it from the full-blown disease, the HIV infection has become known to mean AIDS. Thus, individuals identified as the HIV positive are considered to be terminally ill, even though it may be a decade or so before they actually succumb to death as a result of AIDS. 
A scapegoat or some particular social group to blame is often sought to account for the spread of a major disease. During World War I, for example, prostitutes were the offenders held "guilty" of spreading venereal infection among the innocent American soldiers. This search for the perpetrators also occurred with AIDS. During the latter part of 1982, the American press focused on this new "plague" which was beginning to spread within certain "risk groups" or "target populations." Journalists appeared to avoid use of the term "epidemic" possibly because to do so may have suggested that upstanding citizens of society were also at risk of acquiring the disease.

Lacking an understanding of the etiological agent of this mystery disease, they sought to reduce the threat of randomness while at the same time to reiterate social values and status relationships. By focusing on identified groups of people with morally marginal behaviors, "honest and law abiding citizens" as most individuals think themselves to be, were excluded. This generation and maintenance of feelings of self-righteousness on the part of self-defined conforming members of society, is, of course, a manifestation of what functionalists, following Durkheim, would interpret as one of the positive functions of social deviance.

Predisposition became an important term not only within the medical profession but also within the larger society to aid in understanding who was susceptible to this new ailment. American epidemiologists termed the groups associated as participating in high risk behaviors as the "Four-H Club": homosexuals, Haitians, heroin addicts, and hemophiliacs. Some included an additional group, "hookers" (meaning prostitutes), for a total of five club members (Grmek 1990). Two groups were left out of the club's "H" membership -recipients of blood transfusions and in utero infected newborns. Because they were excluded from the list of morally marginal groups of citizens, these victims were 
able, at least in the minds of the readers of the journalists' articles, to avoid being added to the list of members belonging to the "Four-H Club." Even though considered as part of the "Four-H Club," children were viewed by many as being innocent of engaging in morally deviant behavior. This period of "innocence" (for those victims who acquired the HIV through no fault of their own or involvement in any socially unacceptable behavior) would last only a short time. When uninfected citizens began to feel threatened by direct contact with those diagnosed as the HIV positive, attitudes towards "innocence" changed. This was particularly true in the academic setting when young hemophilic children who tested HIV positive pursued their right to attend public school, over the verbal and physical protests of parents of uninfected children. Issues of whose rights were being protected began to surface, prompting involvement by school boards, state and local governments, PTAs, and other special interest groups.

Medicine has been slow in providing answers. It was not until 1983 that physicians were first able to isolate the HIV. The medical society then began to document the disease's etiology and epidemiology. By 1985, tests screening for seropositivity became available and were required for use by organizations dealing with blood and organs (e.g. American Red Cross, private plasma centers, and organ donor facilities). Since 1985 , the accuracy of these tests has increased so that the numbers of false negative and false positive results have diminished (Grmek 1990, pp. 84-87). The delay in prompt and accurate information concerning the HIV has been illustrated by the number of individuals contracting AIDS through blood transfusions or organ transplants before testing procedures were developed. These "innocent" victims were forced to deal with a society neither ready nor willing to accept the HIV or AIDS as a medical condition that anyone could develop as calmly as they did measles or tonsillitis. Likewise, society has had to deal with the 
"innocence" of these infected individuals, although frequently not in any rational or systematic manner.

Today's knowledge about the nature of the HIV and AIDS was not "discovered" by any one individual or agency. There are four institutions, the Centers for Disease Control (CDC), the U.S. National Institutes of Health (NIH), the Pasteur Institute, and the World Health Organization (WHO), which have been credited with recognizing the epidemiological nature of the disorder, identifying the etiologic agent, and attempting to develop a medical response to combat the illness (Grmek 1990, pp. 13-14). While each of these four institutions has spent varying amounts of money and effort toward the isolation and cure of the HIV and the subsequent disease AIDS, these four organizations have been the major contributors to the bank of current knowledge. During the past few years many health organizations have been working together, sharing information and discoveries in an effort to develop accurate testing procedures, treatment programs, possible immunization for the HIV and a potential cure for AIDS. This is not to say, however, there is no competition among the various organizations in hope of being the first to demonstrate a "break-through" which will bring the institution to the forefront of the world's focus and attention (Grmek 1990, pp. 60-70; Kramer 1991, pp. 118-21; Shilts 1988, pp. 219-26).

With increased understanding of the etiology of AIDS also came increased knowledge of its epidemiology. Since 1985 the HIV has been found to be spread through very specific forms of transmission. While some potential transmission modes of the HIV have not been entirely eliminated as causal factors (e.g. via saliva through deep kissing or biting), neither have they been confirmed as common avenues. As a result of clinical observations, epidemiological research and laboratory experiments, defined routes of transmission of the HIV from an infected 
to an uninfected individual are currently seen as including: (1) sexual contact involving infected semen or vaginal secretions; (2) direct inoculation or injection of blood into body tissues or blood vessels; and (3) mother to child transmission either through the placenta or through breast milk (Grmek 1990). To date, the most common transmission route is the passing of infected semen or vaginal secretions to an uninfected person through rectal or vaginal intercourse.

The demographics of AIDS has changed dramatically since early 1981 when it first appeared to occur only within a well-defined population. By 1985, AIDS was considered to be an epidemic. In 1991, there is no question that AIDS is pandemic. It is estimated that over 100,000 Americans have died of AIDS and that over 1 million are currently infected with the virus, of whom approximately 125,000 are considered to have clinical or active AIDS (Angell 1991). Medical statistics give no indication that the number of individuals diagnosed either with the HIV or fully developed AIDS will decrease. Rather, it is anticipated that the HIV and AIDS will continue to spread from the previously defined "morally marginal" and "deviant" into the mainstream of "law abiding" and "morally acceptable" citizens within society.

On June 7, 1991, the CDC published a report in the MMWR entitled "The HIV/AIDS Epidemic: The First 10 Years." The report provided an update of AIDS from 1981 to 1990 in the United States:

In 1981, 189 cases of acquired immunodeficiency syndrome (AIDS), a newly recognized condition, were reported to CDC from 15 states and the District of Columbia; $76 \%$ of cases were reported from New York and California. Ninety-seven percent of cases reported were among men, $79 \%$ of whom reported being homosexual/bisexual (i.e., having had sex with other men); no cases were reported among children. In contrast, in 1990, more than 43,000 cases were reported, representing all states, the District of Columbia, and the U.S. territories; nearly two-thirds were reported from outside New York 
and California; more than $11 \%$ of adolescent and adult cases were in women; and nearly 800 cases were in children $<13$ years of age. These differences between 1981 and 1990 highlight the dramatic growth and increasing complexity of the AIDS epidemic. (CDC 1991, p. 358).

The report also predicts that by the end of 1991, AIDS will be the second leading cause of death among men between the years of $25-44$, and will be one of five leading causes of death among women between the ages of 15-44 in the United States (CDC 1991, p. 357). This is a frightening prediction to be made of a disease that appears to be barely 10 years old. There are suggestions that AIDS has been in existence for a much longer period of time and that it has only been since 1981 that AIDS has been recognized as a disease in its own right (Grmek 1990, pp. 110-19). If this is the case, the actual number of individuals who have died as a result of AIDS is much larger and the disease is better established in society than we are currently aware of. The actual number of AIDS victims might be hidden in death certificates which list the cause of death as one of many opportunistic diseases associated with AIDS as a result of the inability of the individual's immune system to ward off diseases. Categories of individuals used for reporting purposes by the CDC include: homosexual/bisexual men; women and heterosexual men reporting intravenous (IV) drug use; persons having heterosexual contact with persons with, or at high risk for, the HIV infection; and perinatally acquired pediatric AIDS cases. Exponential growth continues to be illustrated in charts and graphs prepared by CDC statisticians. The only statistical category which has ceased its exponential growth pattern and has begun to level off since 1988 to cases reported through March 1991 has been the number of recipients of transfusions of blood or blood products (CDC 1991, pp. 360-61). 


\section{$\underline{\text { Social Milieu }}$}

Following on the footsteps of the Civil Rights Movement, the Gay Rights Movement, and the apparent relaxing of strict regulations governing moral conduct (including sexual norms and family structure codes which resulted in more freedom of lifestyle), the emergence of a "gay" disease would test the moral boundaries of American society. Even before anything more than its existence was understood about AIDS, the social and moral boundaries between what is conformist and what is deviant regarding sexual behavior and sexual lifestyle were being examined anew.

Homosexual activity, of course, has long been defined as deviant, although it has a less than universal history as such. But with increasing media attention given to AIDS, those with AIDS or related symptoms were identified as social pariahs and the moral boundaries between "them" and "us" or "normal" and "deviant," were being redefined. The fact that homosexual men were initially identified as being affected by the disease provided the "proof" to many heterosexuals that the gay lifestyle was dangerous, improper, immoral, sinful, and other terrible things. Although, interestingly, the fact that lesbians have an unusually low rate of reported AIDS cases was overlooked.

While "doing" homosexual activity has been punished throughout history, even to the extent that those caught engaging in such behavior were severely punished on the spot, the notion of "being" homosexual is fairly recent. According to Gilbert (1981, p. 61), terms such as "homosexuality" and "homosexual" originated in the late nineteenth and early twentieth centuries. These terms were popularized not to describe types of behavior, but rather, they were used to identify a new class of social deviants - a group of males who chose to seek sexual partners of their own sex. 
Since the first people known to contract AIDS in the United States were homosexual men, the disease was identified as being associated with "the gay lifestyle." Through this extension, the notion of "being" homosexual was transformed into being a symptom of the disease, and therefore any gay man was seen as suspect. "Being" homosexual reinforced all of the negative attitudes associated with morally deviant behavior. This reinforcement highlighted the image of how different this group of individuals was from the mainstream heterosexual society. A marker of "otherness" was created when society defined personal and behavioral characteristics of homosexuals as morally and socially deviant. The media contributed greatly to a stereotyped and sensationalized portrayal of the urban gay male lifestyle by focusing on leather bars, bathhouses, "anonymous" sex, promiscuity, and overt flaunting of sexuality (Epstein 1988, pp. 19-20). The negative sanctions associated with "being" homosexual went beyond those associated with "doing" homosexual activity in that an assumption was made that being classified as homosexual signified that the individual was automatically guilty of being deviant.

Initially, physicians identified transmission of the human T-cell leukemia virus (HTLV-3) or human immunodeficiency virus through the medium of body fluids, especially blood and semen, the latter occurring during male to male sexual activity such as penis/anal penetration. In addition to reinforcing the labeling of homosexuals as deviants, drug users and prostitutes were also thrown into the pool of individuals at high risk of contracting the "deviant disease" as additional epidemiological data on AIDS was accumulated.

Those with the HIV or AIDS were thought to be an identifiable group which became the focus of anger and which was labeled as the cause of transmission by a number of non-infected members of society. As with other contagious epidemics 
throughout history such as smallpox, bubonic plague, cholera, poliomyelitis, and contagious forms of leprosy, those affected were seen as being punished for wrongdoing, and were thus seen as being a moral threat to the community as a whole. This response is particularly apt to occur when a phenomenon (e.g. contagious disease) is misunderstood, apparently incurable and appears to affect a large number of people.

The process by which disease becomes viewed as deviance can be analyzed by combining notions of social and medical deviance (Conrad and Schneider 1980). In physical medicine, deviance is seen as a statistical departure from the biological norm. However, Epstein (1988, pp. 6-7) proposes that socially defined notions of what is normal, proper or desirable are inherent in the definition of illness or disease. In fact, medicine is value-laden in its attempts to identify medical deviance (discovery and categorization of diseases); define what is normal in maintaining the overall goal of health equilibrium; outline and prescribe procedures by which any deviance from the norm is dealt; and analyze whether the patient is in some way responsible for contracting the illness (e.g. lifestyle practices, exposure to illness, indifference as to one's own health, and failing to follow prescribed treatment) (Edgley and Brissett 1990; Conrad and Schneider 1980).

Even before AIDS was associated with the gay community and the lifestyle characteristics often exhibited, homosexuality had been medicalized and seen as a form of "mental illness" and, therefore, deviant from the "normal" heterosexual orientation of "respectable" members of society (Conrad and Schneider 1980). Thus, any illnesses or diseases which could be associated with members of the "gay community" (such as venereal diseases) were categorized as behaviors connected with "gayness." These would be seen as deviant not only by medical standards, but also by the social and moral standards established by the conforming members of the 
society. While at times overt and at other times covert and subtle, disease and social identity appear to be positively linked, even though efforts to demedicalize homosexuality have been underway since the 1970's.

As a result of the stigma associated with AIDS, those afflicted are not only seen but very often treated as outcasts or outsiders. These individuals often find that their health insurance benefits have been canceled and new carriers will not accept them due to pre-existing medical conditions, their life insurance policies have been modified to include additional exemptions, their employers are suggesting employment elsewhere, and friends and family turn away as sources of informal support because they have become afraid of contact with the affected individual.

Initially, little was done legislatively once AIDS was identified and the transmission characteristics were thought to be understood (McGuirl and Gee 1985, pp 122-27). It was considered a morally deviant person's disease. Some religious spokespersons proclaimed that this was God's vehicle for punishing the morally corrupt people of the world, those who believed in free sex and non-traditional lifestyles. The strong visibility of the Christian Right and its social agenda through TV evangelists such as Billy Graham, Jimmy Swaggart, Jerry Falwell and Jim Bakker, also played heavily in helping to define virtues for people so that lifestyle behaviors could be categorized as good or bad, right or wrong, moral or immoral.

Society as a whole, through various branches of the media, became aware of AIDS as a disease and how it was affecting a wide range of individuals. It was given almost daily coverage which headlined its mysterious nature. At the same time, the coverage contributed to the increasing hysteria and fear surrounding AIDS and those victims who had contracted the disease. Moral value judgments were placed on the victims. Some of the media headlines which helped promote the link between illness and social identity are pointed out by Altman (1986, p. 17): 
"Gay Plague Baffling Medical Detectives" (Philadelphia Daily News, August 9, 1982). "Being Gay is a Health Hazard" (The Saturday Evening Post, October 1982), "Gay Plague Has Arrived in Canada" (Toronto Star, November 26, 1982). The popular magazine US manages to combine panic and morality by proclaiming: "Male homosexuals aren't so gay anymore," and relating the story of a dying young man who told his nurse that "if I pull through I promise to find a girlfriend."

It was not until the summer of 1985 , however, when Rock Hudson, a member of the upper social class and a celebrity known throughout the world for his motion pictures, was diagnosed with AIDS (he subsequently died on October 2, 1985) that AIDS as an epidemic became a social issue. Even though it was publicized that Hudson was gay, socio-economic status (SES) and prestige boundaries were crossed. It was no longer only a disease of the morally deviant person who lived within the lower to middle class social strata. The media's acknowledgment that a social personality could contract AIDS illustrated that the disease was not contained exclusively within a particular social group and, in fact, was capable of crossing class and ethnic boundaries.

\section{Constructing Moral Boundaries}

The AIDS epidemic raised many questions about individual and societal rights, and challenges to the existing American judicial system began to emerge. As a medically defined contagious disease, AIDS did not fit within the existing laws governing the dichotomy between societal and individual rights when contagious diseases were evident. Previous methods of dealing with contagious individuals such as isolation or quarantine not only violated individual rights, but were quickly recognized as impractical solutions given the large numbers of people infected with the HIV and the costs involved to carry out such endeavors. The law was also challenged as to whether or not a HIV positive person could be barred from attending school, denied insurance, or fired from a job. Not only did the disease 
affect large numbers of people, but many of its victims included socially moral and proper citizens. It soon became evident that AIDS was not something that could be ignored or put aside as being the plight of the underclass, prostitutes, homosexuals or other socially defined morally deviant group.

The "gay plague" suddenly was something that needed to be addressed before it "got out of hand." Although victims from the beginning, the public was hesitant in addressing the needs of those considered non-deviant. However, through publications of a handful of cases (e.g. Rock Hudson and Ryan White), those groups considered non-deviant came to be recognized. Suddenly there were children and blood transfusion victims who did not fit into the previous deviant category. Suddenly various social institutions such as schools, medical facilities, work environments and the like were being forced to deal with members of the community who were not homosexuals, prostitutes or IV drug users, rather they were "upstanding" citizens who were carriers of this contagious and yet little understood disease. Suddenly finding themselves labeled deviant, these individuals began demanding rights they felt were constitutionally guaranteed them, while at the same time the public was demanding protection from these individuals, no matter what individual rights were violated. Being defined as "deviant" can be viewed as both a cause and an outcome of having the HIV or AIDS.

In July 1985, Life Magazine featured a story on AIDS entitled "Now No One is Safe from AIDS" (Dolgin 1985, pp. 198-99). This type of press coverage, in addition to the vagueness and contradictory reports being provided by the medical community, prompted attitudinal swings by members of the community in two directions. On the one hand, non- infected individuals demanded physical protection from any and all contact with persons with AIDS (PWA's). For example, in school, work, health care facilities, those with AIDS demanded that their right to participate 
in all aspects of social exchange not be violated. All levels of government were experiencing pressure to create laws deciding who or what was protected.

Placed in the context of the relationship between law and the maintenance of moral boundaries of societies, it was only a matter of time before various challenges to the judicial system of the United States would be made. Nationally, federal laws were challenged. Likewise, states began seeing a rise in the number of civil lawsuits being filed. At a more local level, organizations began modifying work guidelines and procedures for dealing with PWA's.

The issue of AIDS has affected either directly or indirectly every social institution. Work environments, education, military, religion, health care and insurance are just a few of the institutions which have had to address the social and legal implications associated with noninfected members coming in contact with infected members. As a result the judicial system has been put in the position of codifying the values associated with the redefined boundaries between individual rights and public rights of protection.

\section{Early Legislative Activity}

When social issues develop that raise the question of whether individuals should be protected from the public or the public from individuals, the government has become involved through recommending or enacting rules, procedures and laws. This is especially true when the social event is masked in uncertainty. Historically, the task of containing or eliminating contagious diseases has been seen as so overwhelming that government intervention was necessary in order to expeditiously address the social problem (McGuirl and Gee 1985). In the United States, government action relative to AIDS began officially in 1982 when Congress appropriated funds specifically for research and testing. (Some public health 
agencies, however, had begun their own research efforts as early as 1981.) In 1982, $\$ 12$ million in United States taxpayer dollars was appropriated to the CDC for AIDS research. In 1983 , approximately $\$ 28,736,000$ was allocated to various health agencies, including the CDC, NIH, and the Alcohol, Drug Abuse and Mental Health Administration. As AIDS awareness grew, so did the federal funding commitment for research. The budget proposal for fiscal year 1987 to various health agencies was approximately $\$ 213,000,000$ for AIDS research (McGuirl and Gee 1985, pp. 122-23).

Except for the appropriation of funds, very little legislative activity occurred until 1986 with the first floor amendment to the 1986 Health and Human Services appropriations bill sponsored by Representative Robert Dornan of California (McGuirl and Gee 1985, p. 123). This bill would expand the power of the Surgeon General's existing authority to take whatever actions were necessary to control communicable diseases, such as utilizing AIDS research monies to close places where the disease might be contracted such as in bathhouses and massage parlors. Other early bills dealt with issues such as prohibiting AIDS victims from practicing medicine or offering health care in federally funded facilities, prohibiting discrimination against individuals providing health care in federally funded facilities who chose to wear protective clothing, and denying federal funding to any political jurisdiction which permitted public bathhouses to operate (McGuirl and Gee 1985, pp. 123-34). All of the above-mentioned bills which appeared before Congress came out of California, and appear to be geared toward protecting the public from individuals.

Initially, most of the legislative response began at the state and local levels. Cities such as Los Angeles, Miami, Minneapolis, New York City, Atlanta, Baltimore, Philadelphia, Houston and Chicago which appeared to have the highest 
number of reported AIDS cases were the most active in attempting to enact city ordinances. Those city ordinances included areas of employment, housing, medical and dental services, business establishments and city facilities, and dealt mainly with prohibiting discrimination against individuals suffering from AIDS, those who had been exposed to the AIDS virus, or those who were suspected of having AIDS. Many of the city ordinances further prohibited any person or entity from disseminating information which would encourage discriminatory practices. Those found in violation of these ordinances could be assessed actual damages, costs and attorney's fees, and even punitive damages (McGuirl and Gee 1985, p. 127).

At the state level, in 1983 New York and California passed laws outlining policies for the promotion of AIDS research, distributing information to high-risk groups, and supporting and promoting educational programs regarding AIDS prevention and health care administration (McGuirl and Gee 1985, p. 125). In 1984 Illinois enacted legislation providing that its health department conduct public health campaigns regarding various aspects of AIDS. In 1985, Florida and California passed laws in an effort to protect the states' blood supplies. In the body of the laws, individuals in high-risk groups were encouraged to obtain blood tests which would offer some protection of disclosure of the results. Limited disclosure was to be permitted only on a "need-to-know basis" and if disclosure of individual tests results were violated, civil and criminal sanctions could be imposed on the violator. In 1985 Wisconsin also passed a law requiring informed consent of the test result to anyone other than the individual being tested (McGuirl and Gee 1985, p. 125).

Some of the bills which were considered and rejected by state legislatures included an Ohio bill which sought to declare AIDS to be contagious under the state communicable disease acts and would have allowed state health officials to respond by implementing isolation policies. One of the results would have been prohibiting 
children exposed to the AIDS virus from attending school. The state health commissioner in Texas sought to enact legislation which would have empowered individuals of his agency to quarantine AIDS patients. Pennsylvania and New Jersey considered bills which would have made it a first degree misdemeanor for a person, knowing him or herself to be infected with AIDS, to transmit AIDS through sexual contact. A bill in Pennsylvania would have required a HTLV-III blood test as a requirement for obtaining a marriage license. In addition, New Hampshire sought to enact legislation making it a felony for homosexuals to donate blood (McGuirl and Gee 1985, p. 124).

The initial responses at the federal level to the new disease (known later as AIDS) were few. Except for the allocation of funding for research to various health agencies, it appeared that the federal government was waiting to see if there was a particular direction legislative action should take. McGuirl and Gee (1985, pp. 128-29) identify four foci of early activity which illustrate ways in which the federal government attempted to monitor legislative activity in an effort to deal with the AIDS problem:

(1) Adding AIDS to the list of conditions that may exclude immigrants from entering the United States as permanent residents. (While this was the federal government's initial response, on Thursday, November 29, 1990, President Bush signed a bill which would revamp the current immigration laws. Included is the elimination of the automatic exclusion of AIDS sufferers from obtaining legal status or citizenship. Instead, the decision will be left to the Health and Human Services Department as to whether or not AIDS will be listed as an excludable disease (Beamish 1990; Hilts 1991; Mesce 1991).

(2) Proposed amendments to the social security entitlement programs. This was brought about when the Social Security Administration issued interim regulations which added AIDS to the list of disabilities when it affected the ability of an individual to continue working. As of late 1985, the Administration was also revising policies to include PWAs as benefit recipients. 
(3) Legislative determinations that PWAs are protected from employment discrimination as outlined in Section 503 of the Rehabilitation Act of 1973. The Act prohibits discrimination in employment based on the handicapped condition of the employee in most governmental agencies and by federal contractors.

(4) The military service implemented testing programs for all incoming recruits and all active-personnel. Public rights appear to outweigh individual rights in the military. The new recruit testing positive for the AIDS virus will not be allowed to enlist; and active-duty personnel testing positive are faced with either limited duty or possible discharge. What the military does with the test results, what bank of informational knowledge it is stored in, and who or what has access to such information, is not revealed by the military, even though limited disclosure is guaranteed.

In 1988 the AIDS Amendment of 1988 (42 USC 200, et seq) concerned various programs dealing with AIDS. This Act amended many parts of the existing Public Health Service Act so that it included provisions dealing with specific issues surrounding AIDS. These amendments, however, are not complete.

Currently there are numerous state and federal bills under consideration before judiciary committees which may or may not affect existing laws. Any revisions to the laws presently on the books will in some manner alter the present content of morals and values contained within social moral boundaries.

\section{Maintaining Moral Boundaries}

While there has been substantial activity involving the construction of moral boundaries during the "Age of AIDS," the societal values and morals as reflected in the laws illustrate that important issues involving the individual as well as the public good are being maintained during this period of moral boundary redefinition.

Although the HIV is known to spread through very specific types of transmission, AIDS continues to claim new victims every day. What started out as a mysterious medical condition still has many unknown elements concerning its precise nature. The medical profession, to date, has been unable to fully explain all 
of the questions raised and is unable to accurately predict the future prospects of potential vaccines, treatments or cures. During a time in the United States where there has been an apparent relaxing of strict regulations governing moral conduct, particularly sexual norms and family structure codes, the introduction of AIDS has forced society to test and redefine its existing moral boundaries.

Initially, very little legislative activity occurred as the disease appeared to be contained within certain groups of people who engaged in particular types of behavior. However, as the number of victims continues to increase, and as SES, ethnic, gender and lifestyle choice strata are being crossed, AIDS no longer is being identified as only a morally deviant person's disease. Rather, it has become a disease anyone can "catch" if appropriate precautions are not taken. A redefinition of moral boundaries has begun to take place. Given the magnitude of the direct and indirect social impacts AIDS has and will make, this redefinition process is ongoing and may take years if not decades before societal moral boundaries are seen as being in a maintenance rather than construction phase.

While every social institution has been directly and indirectly affected by the HIV positive and AIDS issues, some institutions have had more media coverage due to the emotional issues surrounding them. Three of the core social institutions to have been intensely challenged are education, health care and work environments. These three institutions will be analyzed as to how moral boundaries are changing given new and proposed laws resulting from the introduction of the HIV and AIDS into American society.

In the next chapter the methodology employed to assess the process whereby the focus and content of proposed and enacted laws pertaining to three major social institutions: business/employment, education, and health care will be presented. 


\section{CHAPTER II}

\section{METHODOLOGY}

\section{SUMMARY OF METHODOLOGY}

In order to look at the extent to which moral boundaries have been modified in response to the AIDS epidemic with regard to business/employment, access to education, and medical care delivery ${ }^{1}$, court cases since 1981 pertaining to AIDS issues which challenged existing laws at the federal and state court levels were obtained. In addition, recognizing the impact media has on influencing social attitudes, newspaper article summaries for stories relating to AIDS since 1981 were also obtained. Once obtained, content analysis was applied to the legal decisions and newspaper summaries in order to identify issues of concern focused on in this thesis. These issues included (1) the number of legal decisions and newspaper summaries from 1981 through 1991 for each of the three chosen institutions, (2) whether these decisions and summaries focused primarily on individual or public interests, and (3) whether these decisions and summaries would be identified as boundary construction or maintenance. The data for each of these categories were then set out in various tables for the purpose of analysis. The analysis and interpretation of the various tables is found in Chapter III.

${ }^{1}$ In this thesis, medical care has been differentiated from health care in that medical care refers to efforts taken in order to restore an individual to his or her previous standard of well-being, whereas health care refers to actions taken in order to maintain an individual's existing well-being. 


\section{INTRODUCTION}

As the second decade of AIDS begins, the documented material involving issues surrounding AIDS has grown at an overwhelming rate. For instance, in 1981 The New York Times Index listed 3 articles concerning a rare form of cancer known as Kaposi's sarcoma linking it to a particular social group (41 homosexual men in New York and California), whereas in 1991 over 500 news articles concerning AIDS related issues were listed in that index.

Similarly, the Social Science Citation Index illustrated an increase in publications pertaining to AIDS-related issues from approximately 30 in 1982 (none were listed in 1981) to over 1,000 in 1991.

A similar growth can be seen in the judicial systems' response to the AIDS epidemic. In 1983 there were four legal decisions from the federal court system and two from the state court system of the United States involving issues related to AIDS. By 1991 the number of such cases jumped to 73 federal and 89 state court decisions reported in the United States. These figures represent the actual number of cases to complete trial (either before a court or a jury) where an final decision or opinion was rendered. This figure would undoubtedly be much larger if all of the cases initiated but settled prior to receiving a court decision or opinion were counted. A similar increase in the number of bills and ordinances pending and passing at the state and federal legislative branches has occurred.

This volume of material would be impossible to subject to research inquiry if criteria were not developed to make it manageable. Business/employment, education, and medical care delivery were selected as areas for concentrated analysis as central institutions, and ones which seemed to be especially vulnerable to, and therefore informative about, shifts in moral boundaries. 
Judicial proceedings are one vehicle through which moral boundaries can be maintained or constructed. It is through the various media, however, that these boundaries are highlighted and brought to the attention of Americans. The media then, while not identified in this thesis as being instrumental in the maintenance and construction of moral boundaries, is an important resource used to inform members of American society as to judicial activity and how it directly and indirectly affects them.

Looking at the relationship between society and law in response to AIDS, it seems reasonable to look at specific social institutions which vary as to the regulatory power of the federal government to regulate them. In addition to being subject to varying degrees of governmental control, these institutions were chosen to help illustrate various aspects of social life which tend to involve highly emotional issues and are likely to be reported by various branches of the mass media. In all three institutions, the issue of rights of the individual versus rights of society emerges, highlighting the societal processes of the construction and maintenance of moral boundaries.

\section{SELECTION OF AREAS}

\section{Business/Employment}

Of the three social institutions selected, business/employment was chosen as being the least controlled (compared to education and medical care) by the federal government, yet very much in the minds of the HIV/AIDS victims as well as others. Issues of job security, insurance benefits, and health safety while on the job bear directly on the dilemma over protection of individual versus societal rights with regard to the AIDS epidemic. Except for guarantees by the federal government (and in some cases individual states and counties) against various forms of discrimination, 
most procedures and guidelines governing how employers deal with employees have been left to the individual management. If the employing firm is unionized, then additional rules or policies may be applicable. However, these are negotiated between the business and the union and are not matters of governmental rule. If the government is the employer, then governmental provisions are applicable. In most businesses the guidelines establishing the rules of conduct are defined under a document entitled Standard Operating Procedures (SOP).

\section{Access to Education}

While business/employment is regulated by governmental policy from one direction, public education is regulated by yet another. The public education system must strictly adhere to specified procedures if federal funds are to be received. In that most state and local public schools are unable to finance themselves solely from the taxes received from residents within their district, state and federal assistance is necessary for continuing operation. As with business/employment, when issues involving children with the HIV or AIDS and public education are mixed, individuals quickly take sides as to whose rights should be protected, the infected or the noninfected.

\section{Medical Care Delivery}

Of the three institutions focused on here, medical care is by far the one the most elaborately regulated by the federal government. For purposes of this thesis, all individuals or organizations providing medical services have been incorporated under the heading of medical care provider. Such professions and organizations include those who in some manner create a provider/patient or medical supplier/recipient relationship (e.g., doctor, dentist, nurse, blood center, hospital, nursing home, pharmaceutical company, or medical laboratory). Each entity within 
the medical care provider rubric must follow multiple guidelines established by federal entities such as the Food and Drug Administration (FDA), American Association of Blood Banks (AABB), Centers for Disease Control (CDC), Department of Health and Human Services (HHS), Public Health Service (PHS), and National Institutes of Health (NIH). Not only does the health and medical care arena include the issue of individual versus societal rights, it may also prove to be the most emotionally volatile of the three in that there still is a great deal of uncertainty surrounding medical care and the HIV/AIDS.

\section{MASS MEDIA AND USE OF CONTENT ANALYSIS}

The United States is a society greatly influenced by the mass media. There was a time when information or news was disseminated to a select few, leaving the community as a whole in the dark. Currently, almost every individual has some access to world events through one or more mass media avenues. Today, the price of purchasing any of the avenues of mass media is relatively minor, or even non-existent (many public places have free newspapers and television viewing), and through the use of satellite transmission, news about current events is available to the masses virtually instantaneously.

Mass media is an integral part of American society. The messages and information distributed to society are often directly and indirectly politically constructed and manipulated. Altheide (1985) defines media power as an influence which goes beyond imagery and the information derived from it. This power

... involves the diffusion of media formats and perspectives into other areas of life. Formats are rules and procedures for defining, selecting, organizing, and presenting information and other experiences. Furthermore, when the temporal and spatial organization of social order are influenced by media formats, then media as a cultural product becomes a dominant cultural form. (p. 9). 
In his analysis of media as a social force, Altheide (1985, pp. 10-11) starts from the point of view that "rational communication involves some kind of preparation, rational procedure, and awareness of the communication context." Communication does not just happen, and people do not communicate just to communicate. Rather, a rational process is involved in its becoming distributed to society, and communication is purposive. Altheide (1985, p. 15) points out that "Media help us define, recognize, use, and adjust to time and space."

This is particularly important in understanding how the majority of individuals in American society acquired the information it would rely on to form opinions on the HIV/AIDS situation. How this information (fact and speculation) was distributed to the American people regarding the HIV/AIDS is relevant to the understanding of the direction and focus legislative activity has taken since 1979 in response to the AIDS epidemic. The angle, slant or message construction presented does in fact influence impressions as to what is being communicated. This is particularly true if the number of media sources is limited so that a narrow viewpoint is relied on.

Most of the information and documentation pertaining to the HIV/AIDS is easily accessible to the public in some form of written communication. A reading of the available literature is therefore vital to an understanding of the relationship between society and law in response to the AIDS epidemic. Content analysis is therefore an appropriate method by which inferences can be made. In a joint definition, P.J. Stone and O.R. Holsti share the view that: "Content analysis is any technique for making inferences by objectively and systematically identifying specified characteristics of messages" (Ogilvie, Stone and Kelly 1987, p. 221). In other words, content analysis is a research technique which can be called upon to make quantitative inferences from what might otherwise be referred to as qualitative 
material. Kerlinger (1986, p. 477) agrees that content analysis is an effective procedure which allows for the study and interpretation of communications in a systematic, objective and quantitative manner in order to measure variables.

\section{Selection of Media Sources}

Before content analysis of archival records was employed to categorize newspaper articles, selection of the article publication source was necessary. Since this thesis looks at changes in societal moral boundaries over time, it was necessary that the publication source make use of an established and consistent indexing system utilized by the organization since 1981. A national publication with a large circulation was sought in order to analyze articles involving AIDS which made the national headlines, as well as a regional publication which would offer a number of articles pertaining to local issues involving AIDS. Through the use of these two levels of newspaper publications (national and regional), it is possible to illustrate the frequency with which information is placed in one branch of the media for general disbursal of information to the public.

While there are a number of local and national magazines which might have been utilized in this thesis, they were not used for several reasons. First, subject index summaries for magazines are more difficult to obtain. Second, as most national magazines are published at most once a week, some of the stories covered deal with topics from the previous week as opposed to newspaper articles which are printed on a daily basis. A third reason for not choosing magazines is that while national magazines are often published weekly, most local magazines are distributed on a monthly basis making it more difficult to compare frequencies. Finally, the daily coverage by newspapers appears to more accurately portray the importance of 
a topic as illustrated by the number and frequency of articles over the periodic coverage by magazines.

The New York Times was chosen as representing a nationally recognized newspaper reaching a large audience and one which publishes a subject index of articles for each year. While it would have been possible to use The Los Angeles Times, The Washington Post, or some other national publication, subject indexes would have been more difficult to obtain. To add a regional comparison, the Newspaper Index (NPI) of the Multnomah County Library, Portland, Oregon, was utilized. This service is a databank of newspaper articles found in The Oregonian, Willamette Week and The Business Journal but indexes only those stories which pertain to Portland, Oregon, or the Pacific Northwest.

The two selected publication sources utilize a subject index categorizing main subject areas. The New York Times publishes a yearly subject index from which the total population of AIDS articles was acquired by gathering all of the articles for 1981 and 1982 under the heading "Cancer" and "Medicine and Health," and since 1983 under the heading "Acquired Immune Deficiency Syndrome (AIDS)." The addition of the category "Acquired Immune Deficiency Syndrome (AIDS)" to The New York Times subject index seems to have become necessary as the total number of articles dealing with AIDS jumped from 3 in 1982 to 129 in 1983. Therefore, creating a subject category specifically dealing with AIDS-related issues would make indexing and searching for such articles easier. As does The New York Times, NPI categorizes articles as to subject content. From January 1, 1981 to September 30, 1986 articles indexed with NPI were located under the category "Acquired Immune Deficiency Syndrome" or "Acquired Immune Deficiency Syndrome (AIDS)." From October 1, 1986 to date, articles are located under the category "AIDS" or "AIDS (Disease)." It appears that as use of the acronym "AIDS" became identified as 
meaning "Acquired Immune Deficiency Syndrome," the NPI subject index switched its indexing practices to the common form of subject identification. Therefore, the NPI population of AIDS related articles since 1981 was located under the headings of "Acquired Immune Deficiency" or "AIDS" or "AIDS (Disease)."

\section{Content Analysis Criteria}

After the publications were selected and article populations gathered, criteria were developed to define how an article would be classified as dealing with business/employment, access to education, or medical care delivery. Because the subject indices for The New York Times and NIP are compiled differently, each index was analyzed separately, although the same classification procedures were used. Each item listed under the AIDS heading for both indices was thoroughly read in order to ascertain the main issue being addressed in the newspaper article.

As each article was read, it was identified as relating to AIDS and business/ employment, access to education or medical care provision by locating key words or phrases within the context of the article which would identify it as relating to one of the three selected institutions. At times key words were enough to identify articles as relating to one of the three institutions, at other times a phrase, and at others the article's title was needed to categorize it. Key words such as "Ryan White" and "Kimberly (Kim) Bergalis" quickly identified the article as relating to specific issues regarding AIDS and society. It was phrases within the context of the article, however, that were most often relied on for interpreting the article's message. For instance, while the word "blood" frequently appeared in articles relating to the medical care category and "education" appeared with respect to access to education category, isolated from the context of the article it might not correctly reveal the article's focus. This is particularly true with regard to the number of articles 
covering various components of the blood industry, and the number of articles currently discussing efforts at educating the public about the HIV and AIDS. Instead, the article summaries in the subject index were completely read in order to locate a series of key words or phrases for identification purposes. For example, since the word "blood" alone was insufficient for purposes of classifying, phrases such as "blood transfusion" or "tainted blood used during surgery" were recognized as fitting medical care provision rather than one of the other two categories.

A tally was kept of how many articles appeared in each newspaper source for the year overall, along with how many news stories related to each of the three social institutions. The total number of newspaper articles dealing with AIDS in each newspaper source was tallied for each year since AIDS was initially documented in January 1, 1981 through December 31, 1991. In addition, the number of articles relating to business/employment, access to public education and medical care provision was also computed. These results are detailed in tables discussed later.

Each article was categorized as fitting the classification scheme of only one of the selected institutions or as falling into a category labeled "other." When it appeared that more than one institution may be the focus in the subject index, the institution which appeared to dominate the article summary (determined by counting the number of identifiers printed in the summary) was deemed as determining the selected institution. Identifiers used to classify whether or not an article fit into one of the three specific categories are detailed below. The category of "other" included all topics not otherwise recognized as relating to business/employment, access to education, and medical care provision.

While The New York Times Index provided a brief summary of the article's context, the NPI for the regional stories provided substantially less information, 
supplying only the title and a few key words and/or a phrase indicating the article's content. Due to NPI's indexing procedures, key words and phrases were used in order to determine whether or not the content of the article related to business/ employment, access to education or medical care delivery with regard to AIDS.

Business/Employment. Articles were classified as dealing with business/ employment issues in relation to the AIDS epidemic if the content of the article summary included matters involving discrimination, bias or problems due to an employee's HIV/AIDS status; matters dealing with employment concerns, policy procedures, administrative changes, or personnel issues relating directly to job performance or behavior in relation to AIDS. Key words and phrases utilized (as they related to business/employment) include for example "AIDS as a handicap," "employee," "employer," "discrimination," "refusing job," and "work." (See Appendix A for the complete dictionary of identifiers used relating to business/ employment, access to education, and medical care.)

Access to Education. Articles were classified as dealing with access to education issues in relation to the AIDS epidemic if the content of the article summary included matters involving a child's HIV/AIDS status in relation to access to public education or day care centers, very often referring to discrimination or disabled rights of the infected child. While colleges and universities were not specifically excluded from classification, it turned out from a reading of the article summaries, the dilemma over access to education remained focused on grades kindergarten through high school. Key words and phrases utilized (as they related to access to education) include for example "attend public schools," "Board of Education," "barred from returning to school," and "attend regular school classes." Medical Care Delivery. Articles were classified as dealing with medical care issues in relation to the AIDS epidemic if the context of the article summary 
included matters involving discussion of medical care providers (to include doctors, dentists, nurses, technicians, medical assistants or others involved in providing medical services) and their relationship to patients regarding issues such as obligations to treat those infected with the HIV/AIDS; concerns over on-the-job infection; policies and procedures for handling patients; mandatory testing of patient and/or physician; personal stories by both patients and medical care providers about direct dealings with the HIV/AIDS in provider/patient relationship; blood and hemophilia; public health policies, rules and procedures established for use by providers; and blood tests prepared for use in the testing of donated blood for the HIV before transfusion occurs. Key words and phrases utilized (as they relate to medical care provision) include for example "American Red Cross," "blood transfusion(s)," "blood supply," "contaminated blood," "patients," and "health care providers."

Other. Topics which were not classified as fitting into one of the three categories included general FDA testing done to isolate and identify the HIV to help provide medical relief to the HIV/AIDS victims; mandatory testing for the purpose of insurance benefits; general educational efforts to heighten public awareness about AIDS; and needle exchange programs. Articles dealing with content and subject matter such as these were classified as "other" and not categorized in more detail.

\section{The New York Times}

In 1981 there were three articles that dealt with a type of cancer later identified as common among AIDS victims, Kaposi sarcoma. These articles were listed under "Cancer" and "Kaposi's sarcoma." None of these articles, however, could be classified as relating to business/employment, access to education or medical care delivery. In 1982, there were again three articles that could be 
identified as dealing with AIDS. One was found under "Cancer" and the other two under "Medicine and Health." Again, none of these articles could be classified as. directly related to the three institutions pertinent to this thesis.

\section{Newspaper Index}

The Newspaper Index available through the Multnomah County Library was also analyzed beginning with January 1, 1981 and ending with December 31, 1991. The first time an AIDS article was indexed in the NPI was in 1983. Prior to October 1, 1986, articles were indexed under the subject heading of "Acquired Immune Deficiency." After that, however, the subject index was shortened to "AIDS" with a reference to acquired immune deficiency. As is true with the total number of articles indexed in The New York Times, the largest total occurred in 1987. The total number of AIDS articles for each classification is indicated in Table I presented in Chapter III.

\section{JUDICIAL SYSTEM}

In addition to utilizing content analysis in order to analyze subject content of newspaper articles, this methodology was also used to identify lawsuits in the United States which at the state court level resulted in appellate determinations, and to identify cases filed at the federal court level which either resulted in legal decisions or jury verdicts. The criteria developed and utilized for indexing newspaper articles were also used in determining whether cases would fit into any of the three social categories selected.

For purposes of this thesis, a computer databank known as LEXIS/NEXIS was utilized for all of the HIV/AIDS lawsuits wherein court decisions were made since 1981 at the federal and state level for the United States. From a 
methodological standpoint a computer search was selected over referring to individual national reporting services in order that a complete population of all the HIV/AIDS cases would be obtained from federal and state court jurisdictions. There are several legal databank services available (e.g. LEXIS/NEXIS, Westlaw) which do similar legal research functions and which would have been relatively easy to access. However, LEXIS/NEXIS was the most cost effective and accessible given time and location of computer availability.

LEXIS/NEXIS is a databank service designed to assist legal research of case law and which allows for the selection of court decisions relating to specific topics. A series of key words are incorporated into a search command and then applied to designated court databanks. Once a search is initiated, a total population of all cases listed in the LEXIS/NEXIS court databank is produced. It is then possible to read through the case decisions and determine whether or not specific case law cited is applicable to the research question.

After requesting a listing of all those cases indexed into the LEXIS/NEXIS databanks as relating to AIDS, each legal decision was read and analyzed using the same criteria of key words and phrases within the context of the decision as were used in categorizing newspaper articles as relating to business/employment, access to education or medical care provision.

A search request of "HIV OR H.I.V. OR ACQUIR! IMMUN! OR HLTV OR H.L.T.V. AND DATE AFT 1980" was activated for the databank of LEXIS/NEXIS listed as General Federal (GenFed) Library of the Courts File. This database includes those courts operating at the federal level which report their decisions to a national reporting publication. Those courts included in the GenFed Library are listed in Appendix B. This request pulled 332 cases from the total number of cases listed in the GenFed Library. Upon reading and reviewing the 
cases, ten were found to contain the key words "acquired immunity" which had nothing to do with AIDS so that the actual number of relevant HIV/AIDS cases totaled 322 .

After refining the terminology used to exclude those cases using the key words "acquired immunity," a search request was done for all 50 states in the United States indexed by LEXIS/NEXIS in the Omni-States Library of the Courts File. The courts included in the States Library are listed in Appendix C. The search request of "HIV OR H.I.V. OR ACQUIRED IMMUNE OR ACQUIRED IMMUNODEFICIENCY AND DATE AFT 1980" produced 270 cases. How each of these legal cases fit into the three social institution categories is shown in Table II discussed in Chapter III.

\section{PERSONAL (INDIVIDUAL) AND PUBLIC RIGHTS}

In addition to looking at the number and frequency of newspaper articles and legal decisions involving AIDS-related issues, each article summary and legal decision was analyzed in order to categorize it as focusing on personal (individual) or public rights issues.

\section{Newspaper Articles}

In order to differentiate between whose rights are being protected, each newspaper article summary identified as dealing with AIDS (in relation to the three social institutions) from the New York Times Summary Index and the NPI was read in order to determine whether the news story focused primarily on personal (individual) or public rights. Key words and phrases utilized for making the determination as to whose rights were being focused on included identifying names of specific individuals, names of social agencies as opposed to individuals (e.g., 
New York Health Department), determining whether the rights of a specific group (e.g., homosexuals) were in contrast to those of the general public. There were, however, a few instances where newspaper articles focused specifically on the issue of individual versus societal rights. In these instances, a category labeled "I\&P Rights" (individual and public rights) was kept. (See Appendix D for a complete dictionary of identifiers used for determining whether the news story focused on personal [individual] or public rights.)

\section{Legal Decisions}

Each legal decision obtained from the LEXIS/NEXIS databank dealing with AIDS-related issues was read to determine whether it focused on personal (individual) or public issues. Typically, lawsuits are filed by individuals. There are times, however, when special interest groups or individuals on behalf of others in similar circumstances (class actions) will initiate legal actions. The names of the parties listed as plaintiff(s) or petitioner(s) were primarily relied upon in determining whether the lawsuit dealt with personal or public rights issues. However, when organizations are listed as the plaintiff(s) or petitioner(s), the case summary also had to be read to determine whether it centered on personal or public rights.

For the most part, when a blood bank or the American Red Cross and American National Red Cross are listed as parties to a lawsuit, they appear as defendants and are being sued by an individual and/or his or her family and beneficiaries as a result of one particular occurrence (e.g., a blood transfusion during surgery). These cases are identified as dealing with personal rights as individuals are suing on their own behalf. There are, however, a few instances where specific blood banks or hospitals are plaintiff(s) against bureaucratic agencies (e.g., The City of San Francisco), organizations or medical laboratories. In this 
instance, the blood banks are often bringing suit on behalf of the public for issues such as reliable testing methods and protection of the release of information. (See Appendix D for the complete dictionary of identifiers used for each of the three social institutions focused on in this thesis as they relate to personal [individual] and public rights.)

\section{MORAL BOUNDARY CONSTRUCTION AND MAINTENANCE}

At the time the newspaper article summaries and legal decisions involving AIDS-related issues were read to determine whether they focused on personal (individual) or public rights issues, they were also evaluated as to whether they resulted in or encouraged moral boundary construction or maintenance efforts.

\section{Newspaper Articles}

Moral boundaries have previously been described as being evidenced by the laws of a given society. In order to determine whether or not newspaper article summaries were to be classified as construction or maintenance, a different approach was used to select key words and phrases as identifiers than was used when looking at legal decisions. Newspaper summaries dealing with AIDS for each of the three social institutions were classified as moral boundary construction if they made reference to litigation, challenges to business or educational rules and guidelines, or any other action that brought about a modification in some form to existing practices. An article was classified as dealing with moral boundary maintenance if it did not deal with any challenge or modification to existing laws, rules, guidelines or ordinances. (See Appendix E for the complete listing of identifiers used for each of the three social institutions focused on in this thesis as they relate to moral boundary construction and maintenance.) 


\section{Legal Decisions}

Determining whether or not a legal decision would be classified as moral boundary construction or maintenance included reading the case summary printed below each lawsuit caption of all the parties involved: (plaintiff(s) and defendant(s); petitioner(s) and respondent(s); and/or appellant(s) and respondent(s). As all of the state court decisions and many of the federal decisions are appeals from lower court rulings, it first had to be decided who was the appellant. Next, the appellate court's determination had to be analyzed in relation to who was appealing in order to determine whether the lawsuit brought about a modification in existing laws or rules. For example, if the plaintiff was an individual appealing a lower court's decision, and the appellate court's decision was to affirm the lower court's ruling, no changes were made to the existing laws and this would be classified as boundary maintenance. If, however, the appellant was the defendant(s) and the appellate court affirmed the lower court's decision, this would be classified as boundary construction in that the plaintiff(s) would have obtained either a monetary award or effected some change in existing rules or guidelines. It is also the case that if the appellate court reversed in part or whole the lower court's conclusion (whether in favor of plaintiff[s] or defendant[s]), then this was classified as boundary construction in that it either changed the initial outcome of the lower court decision, or if the case was remanded, forced the lower court to reevaluate its decision and/or retry the case based on one or more issues specific to the lawsuit. (See Appendix E for the complete dictionary of identifiers used for each of the three social institutions focused on in this thesis as they relate to moral boundary construction and maintenance.) 


\section{INTERCODER RELIABILITY}

In order to evaluate the reliability of the dictionaries of identifiers used in determining whether newspaper articles and lawsuits dealing with AIDS focused on business/employment, access to education or health care delivery; whether or not those same articles and cases centered on personal or public rights; and whether or not moral boundaries were maintained or being constructed, a sample from each of the four databases was presented to a Portland State University sociology graduate student familiar with research design and methodology. A sample of 60 entries, which provided 180 points for matching, was selected from The New York Times Index, NPI, the LEXIS/NEXIS GenFed Database Library, and the LEXIS/NEXIS Omni-States DataBase Library. This sample was then given, along with the methodology section of this thesis and the dictionaries of identifiers used, to the graduate student for classification. The results indicate that of the 180 possible matching points, 161 were classified the same, leaving a balance of 19 discrepancies. This provides intercoder reliability of .8944 or 89 percent. The main area of discrepancy concentrated on how newspaper articles were identified regarding the dilemma over whose rights were being focused on. Although further training might have increased agreement, this was not deemed necessary.

\section{JURISPRUDENCE PRECEDENCE}

Looking at the actual number of lawsuits reported at the federal and state levels does not necessarily explain why some years illustrate an increase while other years a decrease in the number of lawsuits appealed or decided with regard to specific institutions. To help explain why this fluctuation occurs, additional analysis for each of the three social institutions discussed in this thesis is necessary. The 
methodology utilized to determine whether legal decisions, rulings, or federal acts are deemed relevant comes from a reading of the jurisprudence literature. The decisions, rulings or acts selected were referred to at least five times in the literature as to their significance to case law (legal precedence). These legal decisions, rulings, and federal acts are by no means the only ones deemed significant. Instead, they are included as supplemental information relied on in the analysis chapter of this thesis to add depth to the portrayal of legal activity.

Tables compiled from the data collected as a result of this methodology, and how the contents of each of the tables relate to issues surrounding individual and societal rights relating to the AIDS epidemic and how each relates to the social institutions of business/employment, education (access questions), and medical care delivery are examined in the next chapter. 


\section{CHAPTER III}

\section{ANALYSIS \\ INTRODUCTION}

Analyzed in this chapter are the frequencies of newspaper articles and lawsuits filed with regard to AIDS-related issues by year from 1981 through 1991 which are contained in the tables identified in the preceding chapter dealing with methodology. The analysis of these tables is placed within the context of the underlying focus of this thesis -- a look at the causal relationship between law and society in the United States, and the manner in which moral boundaries (evidenced by legal codes) are being shaped through legal response to the AIDS epidemic. Three causal possibilities have previously been suggested: (1) legal change leading to social change; (2) social change leading to legal change; and (3) the interdependent interaction between social change and legal change. Three major social institutions have been selected to assess the direction of causality, both to more clearly focus on the process, and to make manageable the burgeoning volume and number of sources of AIDS' related materials.

During the early 1980's when AIDS was recognized as a serious medical condition, very little was done legislatively with regard to addressing issues surrounding the HIV and AIDS. Since 1985, however, a plethora of media coverage, along with proposed and passed laws, rules and regulations has emerged which directly and indirectly affect every social institution. Business/employment, education (public access) and medical care were selected as three institutions which 
vary with regard to government control and regulation intervention. In the following analysis, the societal response to the AIDS epidemic is examined by explicating the manner in which media exposure, lawsuits, and public and private concerns have mandated alteration of the behavioral guidelines of each of the three selected societal institutions.

\section{SOCIALLY DEFINED PROBLEMS}

How an issue becomes defined as a social problem is something that Wiener (1981) explores. Although her specific focus is on alcoholism, her intent is to explicate the process whereby Herbert Blumer's notions of "collective definitions" arise and are publicly recognized. Wiener (1981, pp. 19-23) sees these phases as including: (1) animating the problem, which encompasses those social processes used to make the problem seem real and subject to improvement; (2) legitimizing the problem, which includes redefining the problem and building respectability; and (3) demonstrating the problem, which involves illustrating just how serious the issue really is. The outcome is based upon the success of the prior phases and results in the enlargement of the bounds of social responsibility so that those delegated to deal with the problem find themselves with a problem that continues to grow. Wiener's (1981) phases can be applied to the AIDS epidemic. For example, by the mid1980's, medical professionals, scientists, researchers and other professionals were called upon to verify the seriousness of the HIV and to begin stressing the need to find the cure. AIDS as a disease is still being redefined as infected individuals no longer include only those who have engaged in deviant behavior, but also those who have not. Demonstrating the problem occurs as more and more people with the HIV/AIDS come forward. The final step of enlargement of the bounds of social 
responsibility is still being addressed by local, state and federal governmental agencies.

\section{MASS MEDIA - NEWSPAPER ARTICLES}

In 1981, few people except for a minority of the medical profession even knew about what initially was defined as an unidentified medical condition. In 1982 as well, very little information was presented to the public concerning this condition. However, by 1983 , the public was overwhelmingly made aware of a new type of medical ailment.

Table I sets forth the total number of articles dealing with AIDS, the total number of articles relating to the three social institutions focused on in this thesis, as well as a breakdown of the number of newspaper articles relating to business/ employment, access to education and medical care delivery as indexed in The New York Times Index, along with the local and regional newspaper articles as identified by the NPI.

Similar patterns of frequency are reflected at the national and local perspective. For instance, nationally and locally there were few articles dealing with what would be termed AIDS printed until the year 1983 and most of those articles focused on medical care delivery issues. In 1983, "Acquired Immune Deficiency Syndrome (AIDS)" gained it own caption in the subject index. The total number of articles dealing with AIDS also jumped to 129. Over the years, the number of AIDS articles has substantially increased. The largest total number of articles relating to the HIV/AIDS for one year in The New York Times was 901 for the year 1987. Since then, the total number of articles has ranged from 450 to 600 per year as of December 31, 1991. 


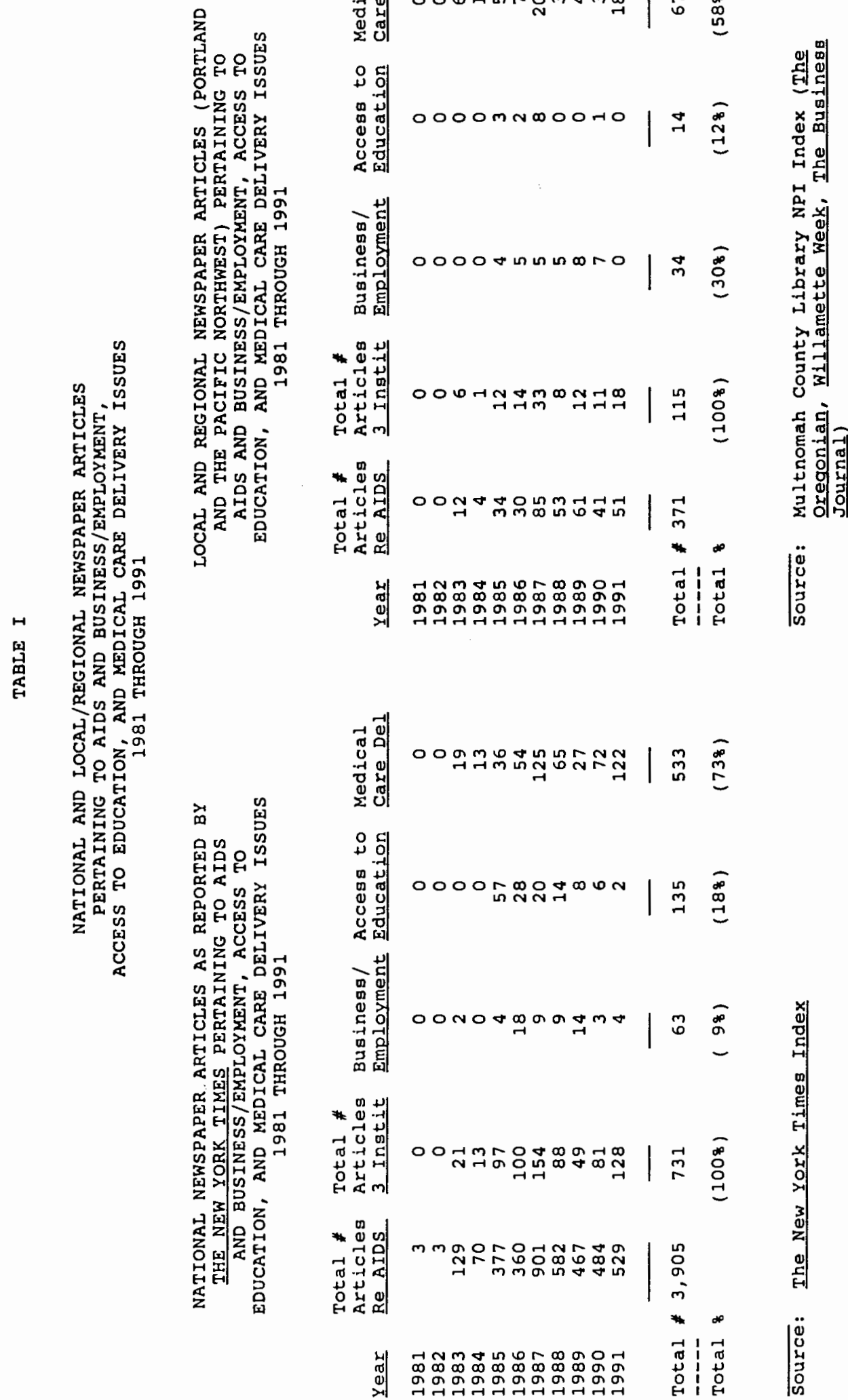


The total number of stories deemed newsworthy dealing with AIDS decreased substantially during 1984 (nationally $54 \%$ from 129 to 70 AIDS-related articles; locally $66 \%$ from 12 to 4 AIDS-related articles). Beginning in 1985, however, the number of AIDS articles escalated nationally over 500\% (from 70 to 377 AIDSrelated articles) and locally over $800 \%$ (from 4 to 377 AIDS-related articles). The next similar pattern occurs during 1987 when nationally the number of AIDS articles increased over $250 \%$ (from 360 to 901 AIDS-related articles) and locally over $280 \%$ (from 30 to 85 AIDS-related articles). Following 1987, clearly the year containing the largest total number of articles to date, a significant drop occurred in the number of newspaper articles available nationally (from 901 to 582 AIDS-related articles) and locally (from 85 to 53 AIDS-related articles). The last four years has also demonstrated a leveling off in the total number of articles dealing with the AIDS printed nationally and locally.

With regard to the three separate social institutions and the number of AIDS articles attributed to each, Table I illustrates many similarities between the national and local totals. For instance, the data relating to medical care delivery during 1987 and 1991 indicate the highest number of articles nationally and locally. This may have had to do with the types of things coming to the attention of the public via the media. For instance, during 1987 there was a great concern over the number of individuals being diagnosed with the HIV/AIDS resulting from blood transfusions they had received during the course of some type of medical care delivery. During 1991, it was determined and substantiated by the CDC that Kimberly Bergalis became infected with the HIV while being treated by her dentist. This particular event set off a national concern over the issue of personal versus public rights.

The main difference noted by comparing the national and local frequencies contained in Table I appears in the total number of articles for the 11 year period 
pertaining to each of the three social institutions. Nationally, medical care delivery is followed by access to education, while business/employment has the least number of articles attributed to it. Locally, however, medical care delivery is followed by business/employment, and access to education is the least reported. This difference can be explained by the fact that news articles dealing with local and regional issues might not have been covered those national stories challenging existing laws, guidelines, rules, or practices. National stories focusing on the rights of children to public education (e.g., Ryan White, the Ray brothers, and numerous unnamed children challenging the educational system during 1985) would not have appeared in the NPI which focuses exclusively on local and regional stories. What propelled the narratives of a selected children to become national stories? It might be that these particular children came to represent the plight of nondeviant children with the HIV or AIDS throughout the United States. Likewise, the NPI reports a larger percentage of articles dealing with business/employment stories than stories covered at a national level. Many of the stories reported by NPI include a series of articles over a period of time pertaining to one rather than multiple incidents.

The number and frequency of newspaper articles relating to the AIDS epidemic, and in particular to each of the three social institutions focused on in this thesis, is important in understanding what Altheide (1985, p. 9-11) meant by referring to the media as a power capable of influencing social order and being a social force. As Americans became exposed to more and more information (through multiple forms of the media) dealing with various aspects of AIDS, they were able to develop personal perspectives that fit within the framework of their own values and mores. 


\section{HIGH VISIBILITY INDIVIDUALS}

In addition to the number and frequency of newspaper articles which help individuals form their opinions and beliefs, certain events which occur in society can also greatly impact what kind and how much information is disseminated to the public.

There have been several specific social events which when they occurred were highly publicized through several types of mass media. The issues surrounding the particular event, in addition to the manner in which the information was presented to the public, may have impacted the attitudes of the recipients. Four such social events are briefly outlined below to help illustrate this point.

After Rock Hudson's death in October of 1985, his companion Marc Christian filed a lawsuit against the Hudson Estate on the grounds that he was not informed of Hudson's medical condition, even after Hudson knew he had AIDS, and that no preventative measures that could have prevented the spread of the disease to him were taken during their relationship. Christian was awarded $\$ 21.75$ million by a California jury which was a landmark decision for the sexual partners of those who fail to reveal their medical condition. The jury verdict was reduced to $\$ 5.5$ million and upheld on appeal. Rock Hudson's estate thereafter agreed to an undisclosed, out-of-court settlement. As of October 6, 1991, Christian tested negative for the HIV (Scott 1991). Subsequent to Rock Hudson's death as a result of AIDS, several high visibility individuals (such as Elizabeth Taylor) began to sponsor and participate in fund-raising efforts for AIDS research, and to speak before legislative bodies on behalf of AIDS victims.

When 13 year old Ryan White was barred from attending school in 1985 because he had AIDS which he contracted while being treated for hemophilia, he 
gained national attention and sympathy when he and his mother challenged the Western Middle School Board of Kokomo, Indiana by filing a lawsuit to protect his individual rights to attend public school. Not only was his personal story disseminated through various forms of media, social celebrities (e.g., Elton John) began to take personal interest in his situation and attempted to raise money and educate the public about AIDS.

After the CDC in 1990 confirmed that Kimberly ("Kim") Bergalis obtained the HIV from her former dentist who had recently died of AIDS, the number of news stories involving medical care delivery issues rapidly increased. After filing a lawsuit in September of 1990, a settlement was reached with the estate of the dentist, David Acer, for $\$ 1$ million in January of 1991. After the settlement, Bergalis appeared before the Congress, gave speeches, and appeared on a number of television talk shows informing the public on how she became infected with the HIV. She was active in her efforts to allow individuals the opportunity to make the choice in whether or not they would be treated by someone with the HIV or AIDS until her death on December 8, 1991.

More recently, the announcement by Magic Johnson has set the stage for many news stories looking specifically at the sexual promiscuity often associated with the sports world. In that Johnson denies he is homosexual, an IV drug user, or has received tainted blood during an operation, the only transmission avenue left open is heterosexual intercourse. Since his public announcement and retirement from playing professional basketball for the Los Angeles Lakers of the National Basketball Association, Johnson has become a spokesperson on educating young people about AIDS and safe sex practices, and was appointed by President George Bush to the National Commission on AIDS. 
These four events are examples of how a particular event can transform an otherwise unpopular and avoided subject into a highly visible and frequently discussed topic. Rock Hudson illustrated that AIDS victims could be found among those individuals who were wealthy and/or prestigious. Ryan White legally challenged his belief that he had a right to public education and that the only dysfunctional thing he had done was to be born with and to be medically treated for hemophilia. Kimberly Bergalis established that it was possible for those obtaining medical care to be infected with the HIV by their provider. Currently, Magic Johnson demonstrates that even heterosexual individuals can become HIV positive through unsafe sex practices.

While it is true that there were numerous articles, especially at the national level (see Table I -- The New York Times Index), covering the stories regarding Hudson, White and Johnson, there was also strong exposure from other mass media avenues allowing for increased opportunity by the public to form opinions with regard to the AIDS epidemic.

\section{LEGISLATIVE ACTIVITY}

While it is the case that today's social event becomes this evening's news and tomorrow's newspaper article, the filing of a legal decision or ruling may take years to come to a printed conclusion. Such is the case with the number of legal decisions and rulings reflected in the data contained in Table II (federal and state court decisions). Illustrated in Table II is how legal cases fit into one of the three social institution categories of interest.

As with Table I (national versus local) dealing with frequency of newspaper articles, the number of legal decisions illustrate similar parallel patterns between federal and state levels of government. In Table II, the first legal decisions reported 
范 범

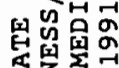

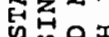

的昆品

出品要

百吴䍃

थ苾点

田吕可

率的

号。四牙

起记的

䁬罢

的究

足望

द्र

굴

部

重的鱼

为

舅䆓

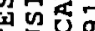

它品

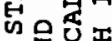

点

点

类藏

的鱼

品息

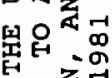

影

空总

吸昏

舟品

量品

영응

舁的

兵包

붕ํㅇㅁํㅇ

包论

至会

要䡗

的昏

号罣昫

㟧盗舅

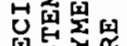

鱼为

雷窗

墨

8

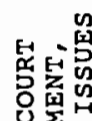

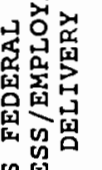

品舅四

它罗焉

苟

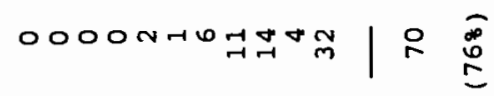

오의

00000ntamoo |r

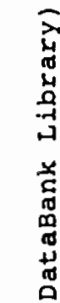

o000700nmmo

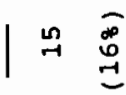

*

न

菏

0 0 0 0mmn

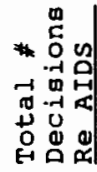

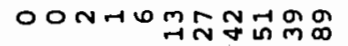

$\stackrel{\circ}{n}$

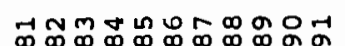

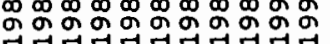

㕝|

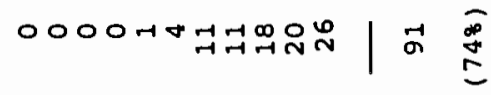

오의.

跎 命

品虽皆

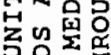

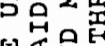

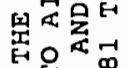

ż

记瓷

哓昆

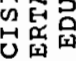

돔음

最鼠的

才ू

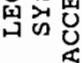

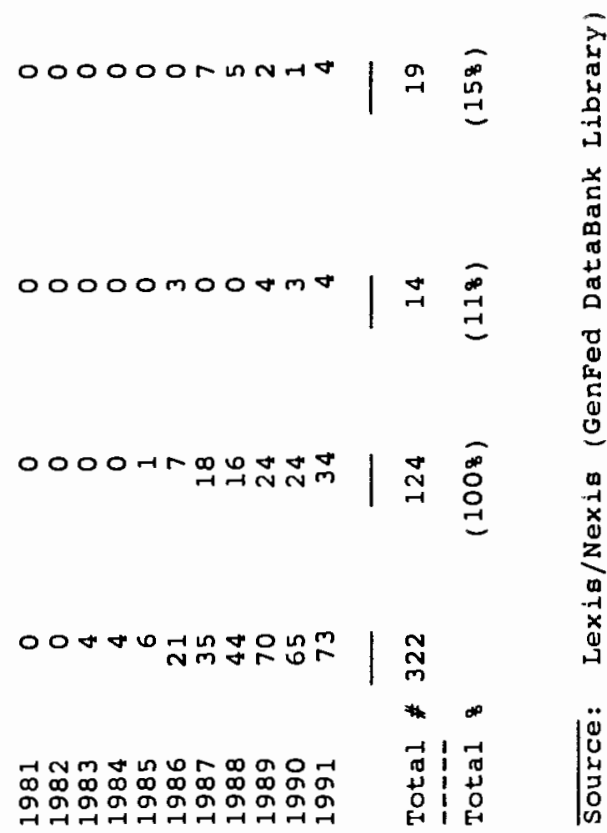


occurred in 1983 at both the state and federal levels, two years after AIDS was first identified as a disease, and had nothing to do with business/employment, access to education or medical care delivery. It was not until 1985 that decisions were reached at the federal and state level dealing with these institutions, primarily medical care delivery.

Of the total number of cases dealing with AIDS-related issues, less than $40 \%$ deal with business/employment, access to education and medical care delivery at the state and federal level. At the federal level, a number of court decisions concern military employment, insurance testing (e.g., life insurance companies), and prisoner rights. At the state level, a number of court decisions concern rights of the arrested and/or criminal, paternity proceedings, divorce grounds, child custody or visitation rights, libel and slander, and landlord/tenant issues.

Of those decisions identified as relating to the three social institutions referred to in this thesis, medical care delivery is by far the most frequently reported. A review of the individual cases indicates that a majority of these decisions deal with blood transfusion issues where one or more individuals are listed as plaintiff(s) and the American National Red Cross, other blood banking facilities, and various hospitals are listed as defendants.

The main noticeable difference between federal and state cases presented in Table II occurs in the sequential ordering of social institutions by number of cases, and when the most current decision has been reported. As the data in Table II indicate, at the federal court level medical care delivery is the most frequently reported, with access to education second, and business/employment third. At the state court level, Table II reflects the fact that while medical care delivery is by far the most frequently cited, business/employment is second, and access to education is third. This difference can perhaps be explained by the fact that it takes longer to 
reach court decisions at the federal level as these are often cases involving diversity of citizenship (e.g., parties to the lawsuit reside in different states so that which state has controlling jurisdiction is an issue), or cases appealed from the lower appellate state courts. It not only takes longer to reach a decision due to the added level of complexity (additional appellate court jurisdiction, or interstate parties to lawsuit), but these federal decisions carry more legal weight with regard to subsequent lawsuits filed on similar issues. Thus, while there are many more federal court decisions as indicated in Table II regarding access to education, the decisions reached in these cases may be laying the foundation of law to discourage lawsuits at the lower state court jurisdictions.

In comparing media exposure (Table I) with court decisions (Table II), an approximate two to three year delay appears between the time when a substantial number of newspaper articles first began to appear (1983) and when a significant number of lawsuits concluded (1985 and 1986). This two to three year period is frequently estimated as the minimum amount of time necessary from the filing of a lawsuit through legal determination. If a lower court decision is appealed, the amount of time necessary to reach a final determination is prolonged. It may even be the case that an appeal may result in a reversal of the lower court decision so that the lawsuit has to be retried on all or some of its original issues.

\section{INDIVIDUAL/PUBLIC RIGHTS AND MORAL BOUNDARIES}

\section{Media Exposure}

One of the main controversies concerning AIDS deals with the issues of whose rights are being protected. Do the rights of the AIDS victim outweigh those of the general public, or vice versa? The issue of rights is the main component in the number of legal challenges which have occurred at the state and federal court 
level of the United States judicial system. How have these legal challenges affected the particular American moral boundary concerning individual versus public rights? For purposes of this thesis, moral boundaries have previously been defined as the laws of a given society. If legal challenges to current laws by either the individual or public results in modifications, enactment of new or elimination of old laws, then the original moral boundary has in some fashion been altered.

The mere mention of the AIDS epidemic, however, does not qualify as a challenge to existing moral boundaries. News articles focused on educating the public about the HIV and AIDS do not seek to change existing laws and rules, but rather to inform society. These news stories are not challenges to established moral boundaries and are thus seen as maintaining the status quo.

It is not only legal challenges, however, that give rise to the possibility of moral boundary changes. Individuals and special interest groups can influence legislative activity. Media, especially newspapers, educate a large number of people about particular topics and, in so doing, help individuals formulate and crystalize into opinions and beliefs what may have earlier only been thoughts or concerns.

Tables III and IV contain data which reflect the number of newspaper articles at the national and local levels that dealt with individual or public rights, and that focused on moral boundary construction or maintenance.

In order to avoid the quandary of deciding whether or not an article would be classified as focusing either on individual or personal rights when in fact the subject dealt specifically with the dilemma over whose rights should be protected, a separate category labeled "I\&P" was created to help maintain intercoder reliability. These "I\&P" articles are thus categorically separated from the dichotomy of individual versus public rights. As suggested from the data in Table III, there have been very few articles (2\% at the national and local level of all AIDS articles defined as 


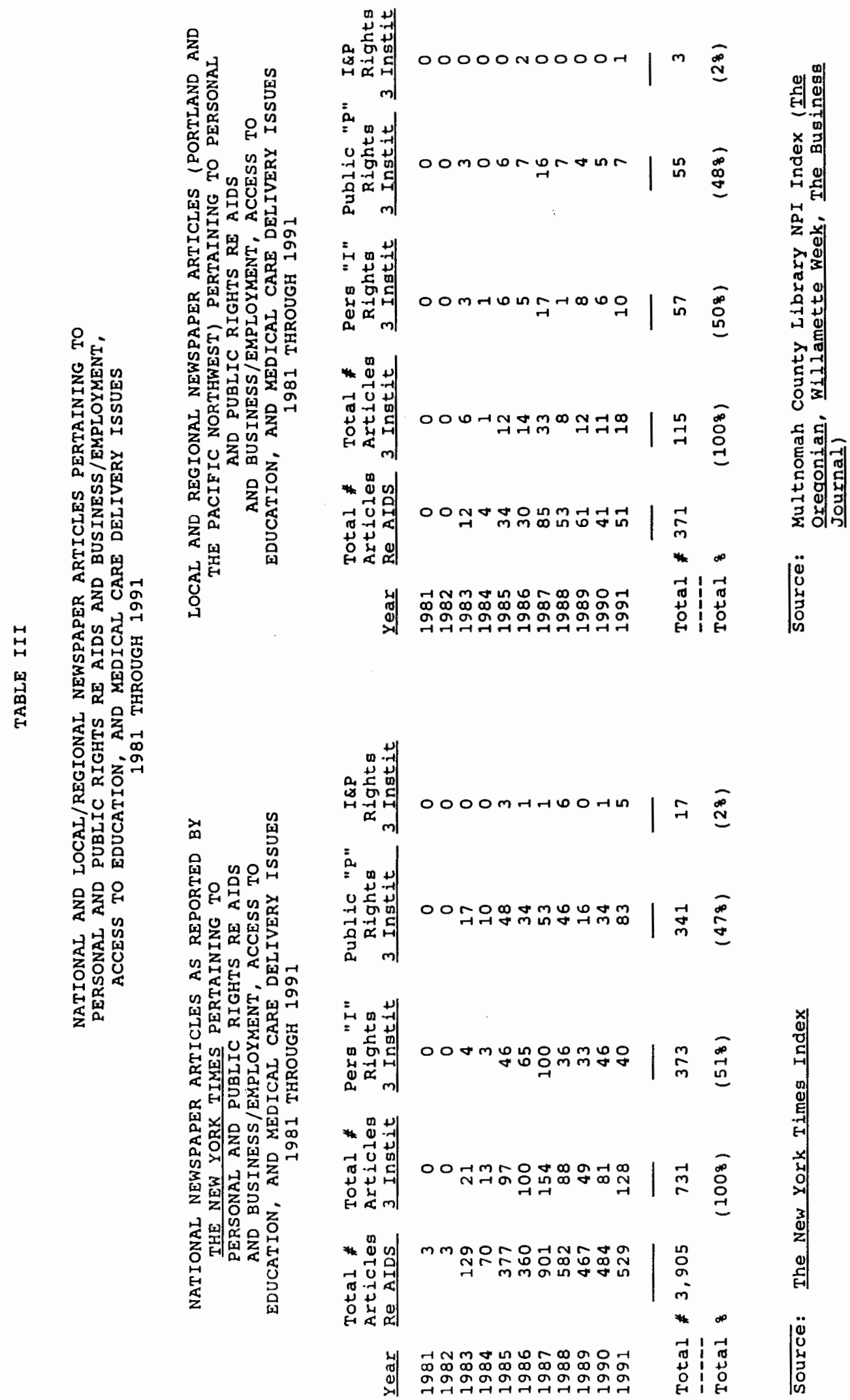




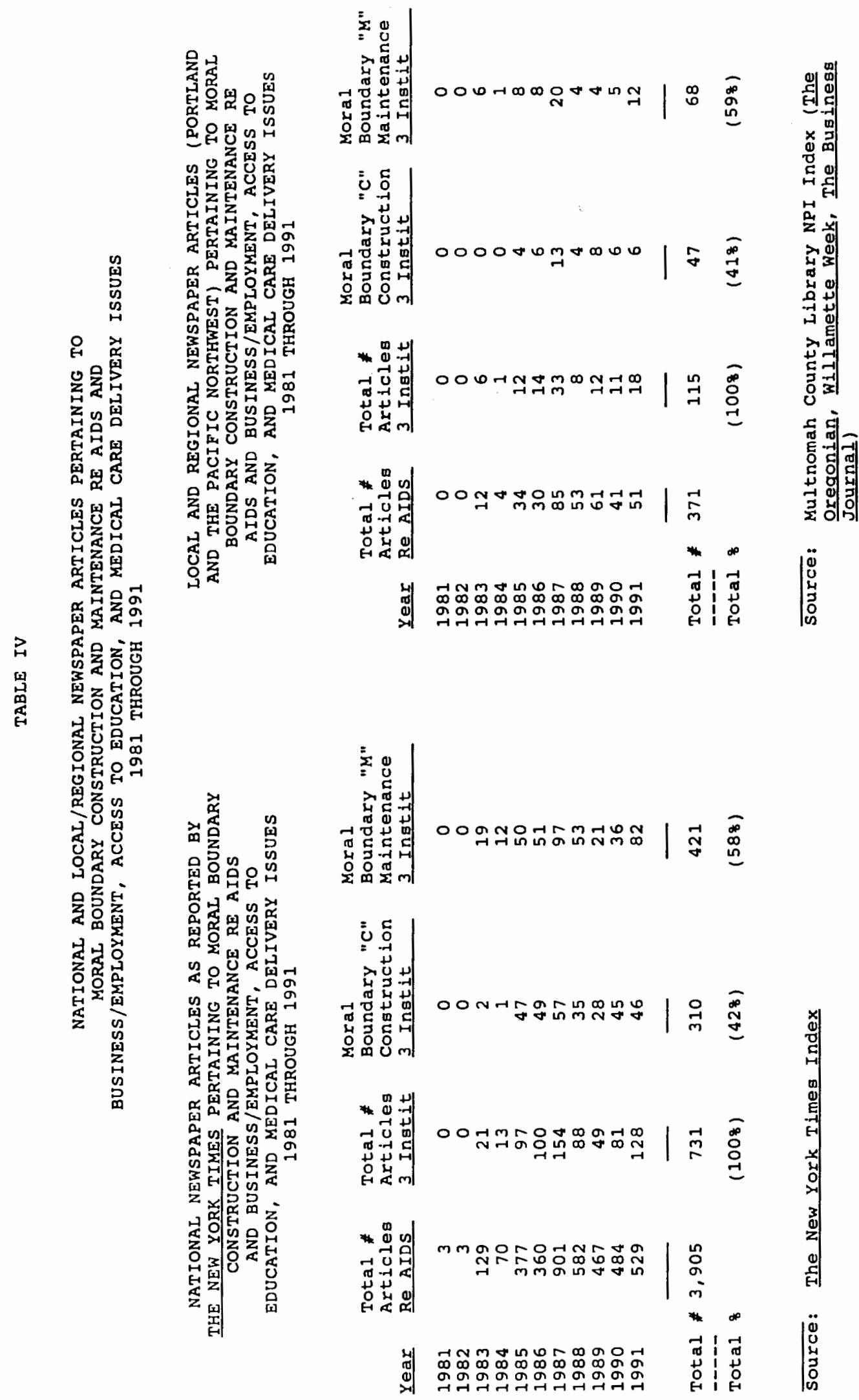


relating to the business/employment, access to education, and medical care delivery) which deal directly with the issue of whose rights should be protected. The data in Table III suggest that newspaper articles dealing with AIDS at both the national and local level seem to be evenly split on which perspective of the rights dilemma is being reported. For example, at the national level $51 \%$ of the total number of AIDS articles relating to the three institutions focus on personal rights, while $47 \%$ of the total deal with public rights. A similar pattern appears at the local level as $50 \%$ of the total number of AIDS articles relating to the three institutions focus on personal rights, while $48 \%$ deal with public rights. The data in Table III not only illustrate a fairly even split between the dichotomy over the issue of right, but this pattern is similar at the selected national and local newspaper reporting sources.

The individual year and category differences of the data contained in Tables III and IV may be explained by the subject indexing methods each table relied on. For example, in 1987 Table III reflects that out of 154 AIDS articles related to the three institutions, there were 100 national articles that focused on individuals rights and 53 that dealt with public rights. The data in Table III (local newspaper source) sets forth that for the same year, the number of local and regional articles was almost evenly divided with 17 concerning individual rights and 16 concerning public. These differences can be explained by considering that the local and regional indexing scheme would not cover issues of national interest such as those which occurred in 1987. In 1987, many of the articles that dealt with individual rights concerned educational challenges (e.g. Ryan White) and an increasing number of individuals diagnosed with AIDS because of some involvement with blood products.

The data in Table IV can be interpreted as suggesting that of the total number of national and local newspaper articles dealing with AIDS as to the three selected 
social institutions, there have been slightly more articles concerning moral boundary maintenance topics (nationally $58 \%$ and locally $59 \%$ ) than there have been concerning topics which may be seen as challenging the established status quo and are therefore categorized as moral boundary construction (nationally $42 \%$ and locally $41 \%$ ). As an existing social order, including laws and rules outlining appropriate behaviors and conduct, is not easily changed, it does not seem surprising that there are more moral boundary maintenance articles than there are boundary construction articles. What appears to be significant is that at the national and local level of newspaper reporting, the percentages calculated for boundary construction and maintenance are almost identical.

Tables III and IV present data which can be interpreted as indicating that during the 11 year period of reporting, there is little difference between The New York Times (a national newspaper reporting publication) and the NPI (a local/regional publication index) as to whether the content deals with issue of personal versus public rights, and whether or not the article can be seen as challenging existing moral boundaries or not.

\section{Jurisprudence}

As defined in this thesis, laws which are enacted in a society comprise the moral boundary which individual members rely upon to formulate and solidify their values and beliefs. The issue of rights is one frequently challenged. Freedom of speech and press, freedom of religion, freedom of information or disclosure, right to due and speedy process of law, and rights involving protection, are often challenged through the judicial system. For each of the institutions selected for this thesis (business/employment, educational and medical care delivery), legal challenges have occurred directly attacking the existing laws or moral boundaries concerning the 
question of rights. A challenge, however, does not necessarily mandate a change in the standing order. Rather, a lawsuit must be evaluated by the court as to the facts and the grounds upon which the matter is being filed, and then decided on its merit by judges and juries.

Once a lawsuit has been filed, each side to the case must establish a legal foundation relying upon not only established laws, rules and guidelines, but also on the history of case decisions that have come before concerning the issues outlined in the present lawsuit. The principle of precedent (e.g., precedent setting case or decision) is closely linked to the notion of guidelines, models or patterns of decision outlined by Pound (1951) in his definition of law. Precedent is that which offers a source of continuity with the past by making attempts to guarantee that all individuals will be treated alike. Individuals living in modern United States society, however, frequently question the validity of these earlier "precedent setting" decisions. Changes which occur in the economic, social and political aspects of society create new demands which need to be addressed. When previous guidelines or models of conduct are questioned and challenged by members of society, the judiciary is turned to as a source for providing the ultimate authority. This is particularly true when rights guaranteed in the United States Constitution are being challenged.

The Supreme Court of the United States relies on precedent when considering cases presented for review. The court has frequently exercised its right to overrule a prior constitutional decision when it believes the prior principle was incorrect. Such was the case involving segregated schools. For over 50 years, the case Plessy v. Ferguson, 163 U.S. 537 (1896) guided the court with the doctrine of "separate but equal." However, in 1954, the court reversed its prior adherence to this precedent with the case Brown v. Board of Education of Topeka, 347 U.S. 483 
(1954) (Cecil 1983, pp. 57-59). Thus, decisions are reversed or new rulings are made as perceptions of law and justice develop and change over time.

This concept of precedence is important in that it provides an explanation as to why the number of lawsuits being filed in response to the AIDS epidemic does not continue to rise. Tables V and VI contain data which reflect the number of legal decisions made at the state and federal level of the United States judicial system dealing with AIDS and business/employment, access to education, and medical care delivery issues. As with Tables III and IV, the table categories have been divided into individual or personal rights, and moral boundary construction or maintenance. While discrepancies occur between years as to the total number of cases identified to each category, the percentages for the 11 year period for each category concerning rights and moral boundaries are very similar.

The main notable difference in Table $\mathrm{V}$ appears in the percentage totals for individual rights and public rights. The majority of the cases reported at both the federal and state court system deal with personal rather than public rights. This can be explained by the fact that for the most part, individuals will bring a civil action against an alleged wrongdoer. It has been only recently that lawsuits have been filed and carried through the appellate process on behalf of many people (class actions) or groups. There may a shift from personal to more public rights lawsuits as is suggested by the data in Table $\mathrm{V}$ for the state court system during the last four years.

There is also another significant difference between percentages between the federal and state court systems. Where the federal decisions of Table V indicates $87 \%$ of the case decisions deal with individual rights, state decisions indicate $72 \%$. Likewise, where Table $\mathrm{V}$ indicates $13 \%$ of the federal court case decisions deal with public rights, at state court level $28 \%$ of the case decisions deal with public rights. 
落

品点琶岛

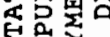

为

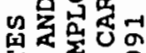

息

帛最的最

的品罗

㽞量员

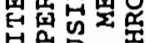

包员宙

照䍃

是四

법

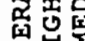

品

눈

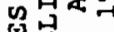

是

$1{ }^{2}$

密余方

艺的苜的

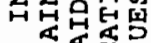

在顿岛

总息畐㽞

员武岛。

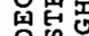

包的界界

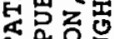

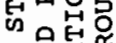

虽采䍃

H

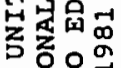

ơ

崖然

嚳

Z 업

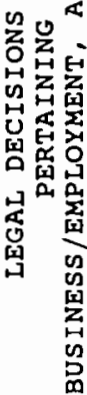

旨垈

傗

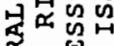

畐泡身

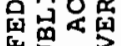

ज踏

息只星

通远国

जा

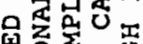

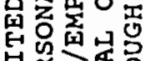

舀记员

淟密

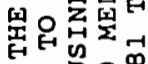

层品号尔

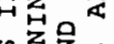

设是号

号乐的

牙舅品

ब远

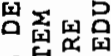

发会

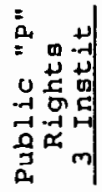

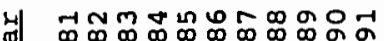

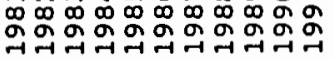

ON

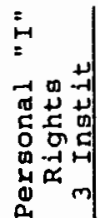

000007non

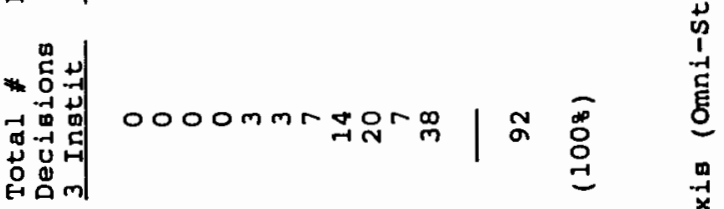

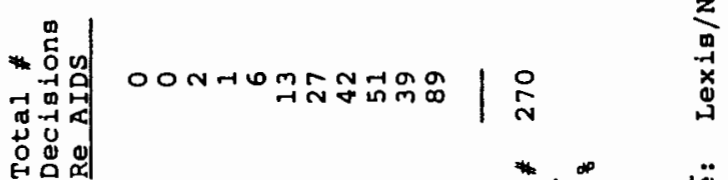

भ

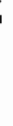

恋

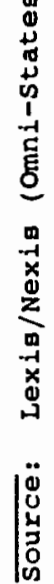

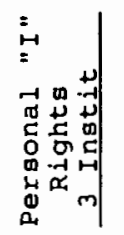

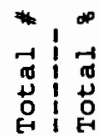

"4)

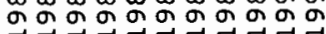

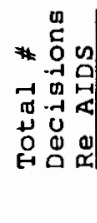

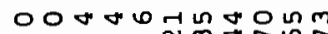

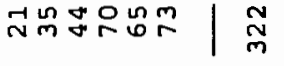

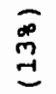

00007นกำกำำำ

$\mid \stackrel{\infty}{\stackrel{\infty}{0} \underset{-1}{\infty}}$

స్․․

范

\%

*

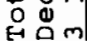

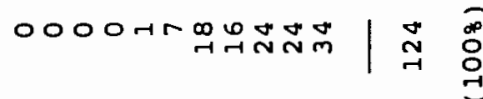

નનનનનનનનનન

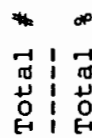

$\stackrel{\infty}{\circ}$

声 


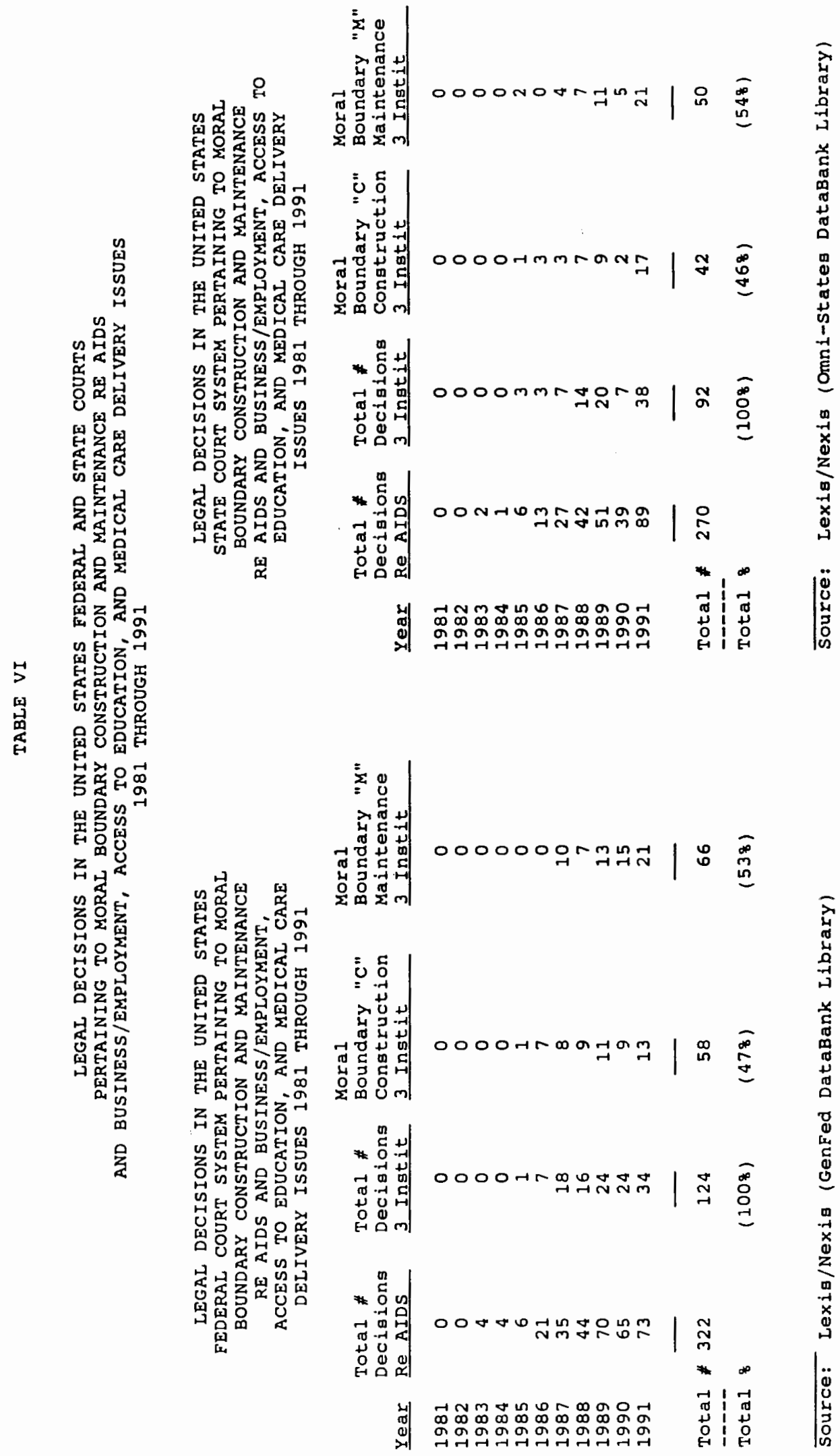


While there is no clear explanation as to why there is a higher percentage of case decisions dealing with public rights at the state court level, it seems reasonable to conclude that the increase may be brought about as more special interest groups within states are challenging their state laws, which often vary from state-to-state. For instance, some of the public entities that were identified as parties filing lawsuits when the LEXIS/NEXIS databank for state and federal cases dealing with AIDS was accessed include Citizens for Responsible Behavior, Citizens for Uniform Laws, Racine Unified School District, and class actions where a number of individuals join together in one lawsuit.

The data in Table VI can be interpreted as suggesting that of the total number of federal and state court decisions dealing with AIDS as to the three selected social institutions, there have been slightly more decisions concerning moral boundary maintenance topics (federal court 53\% and state court 54\%) than there have been concerning legal decisions which may be seen as challenging the established status quo and are therefore categorized as moral boundary construction (federal court $47 \%$ and state court 46\%). As is true with the findings in Tables III and IV, an existing social order, including laws and rules outlining appropriate behaviors and conduct, is not easily changed. It is therefore not surprising that there are more moral boundary maintenance articles than there are boundary construction articles. What appears to be significant is that at the federal and state court level of legal decisions, the percentages calculated for boundary construction and maintenance are almost identical.

Table $\mathrm{V}$ presents data which can be interpreted as indicating that during the 11 year period of reporting, a majority of legal decisions at the federal and state court level focus on individual rights. It is important to note, though, that there are more decisions involving public rights at the state rather than at the federal court 
level. Variations in state laws and the influence of special interest groups may explain this variance.

Table VI presents data which can be interpreted as indicating that during the 11 year period of reporting, there is little difference between legal decisions at the federal or state court level as to whether the content deals with issue of whether or not the article can be seen as challenging existing moral boundaries or not.

\section{IMPORTANT CASE LAW RELEVANT TO BUSINESS/EMPLOYMENT, ACCESS TO EDUCATION, AND MEDICAL CARE DELIVERY}

While Tables III, IV, V, and VI provide data for a statistical foundation upon which to make interpretation on trends involving issues of individual or public rights and moral boundary construction or maintenance in response to the AIDS epidemic, each institution focused on in this thesis has responded to AIDS in its own manner. Looking at the types of cases and court decisions rendered provides additional information as to the relationship between society and law in response to the AIDS epidemic.

\section{Business/Employment}

The United States Code as of mid-1989 did not contain a comprehensive policy on any type of handicap discrimination. Instead, it seems that Congress has adopted a piecemeal approach to addressing the problems of persons with physical or mental impairments, and has left the bulk of the private-sector policymaking decisions to the individual states. The Civil Rights Act of 1964, while being the foundation upon which most of the rights of persons with disabilities are based, does not directly address discrimination against handicapped individuals by businesses and employers. It was not until 1988 that the Fair Housing Act of 1968 included provisions to address discrimination against handicapped individuals (Closen, 
Hermann, Horne, Isaacman, Jarvis, Leonard, Rivera, Scherzer, Schultz and Wojcik 1989, p. 284).

Traditionally, employers have had complete discretion to refuse to employ individuals based on an unwritten "employment at will" rule. During the past few decades, however, laws have emerged which focus on preventing discrimination, including discrimination against individuals with disabilities. These laws have to some degree limited the freedom employers have had in the past concerning the manner in which they deal with their employees.

In 1973 several existing federal laws dealing with "handicapping conditions" and "disabilities" were collected and put into one document entitled the Rehabilitation Act and were codified beginning at 29 U.S.C. Sec. 701. The main point of this Act was to integrate persons with disabilities into the mainstream of American society. This was evidenced by the Act's statement of purpose:

... to develop and implement, through research, training, services, and the guarantee of equal opportunity, comprehensive and coordinated programs of vocational rehabilitation and independent living. (29 U.S.C. Sec. 701)

The Rehabilitation Act of 1973 also contains provisions which affect the policies of federal agencies as employers (Sec. 501). In addition, it extends equal opportunity guarantees to handicapped persons who are employed by federal contractors (Sec. 503). Finally, the Act also directly impacts private or public sector programs which receive federal funding (including federal and state agencies) (Sec. 504). The Rehabilitation Act will therefore govern businesses differently depending on who or what agency manages them and from where their financial source comes (Leonard 1987, p. 110-111; Sloan 1988, p. 29).

Since 1973 the Rehabilitation Act has been amended several times. Two of those amendments directly affect individuals with AIDS. The first occurred in 1974 
and expanded the definition of a handicapped individual to include persons who are perceived and regarded by others as being handicapped. Section 7 (29 U.S.C. Sec. 706) provides in part:

(7)(B) [t]he term "handicapped individual" means, . . a any person who (i) has a physical or mental impairment which substantially limits one or more of such person's major life activities, (ii) has a record of such an impairment, or (iii) is regarded as having such an impairment.

The second was part of the Civil Rights Restoration Act of 1987 which further modified the definition of "handicapped individual" to clarify how the policy stood with regard to individuals impaired by contagious conditions and to better define the jurisdictional reach of the law in the private sector. Section 7 (29 U.S.C. Sec. 706) provides in part:

(7)(C) . . . as such sections relate to employment, such term does not include an individual who has a currently contagious disease or infection and who, by reason of such disease or infection, would constitute a direct threat to the health or safety of other individuals or who, by reason of the currently contagious disease or infection, is unable to perform the duties of the job.

Discrimination against individuals with AIDS in business and employment raises the question of whether or not laws regarding discrimination against handicapped individuals apply to persons affected by diseases caused by transmissible agents such as the HIV. When AIDS was first recognized in 1981, there was no appellate case law directly on point. There was one case where a court relied on the Rehabilitation Act and held that mentally retarded elementary school children infected with hepatitis B virus could not be segregated within a special education program based on the virus alone. [See New York State Association of Retarded Children v. Carey, 612 F.2d 644 (2nd Cir. 1979).] However, the basis for finding Section 504 of the Act applicable was that the children were mentally impaired and that children of normal intelligence who were infected with hepatitis 
were not likewise segregated. Thus, the discrimination was found to be based on mental impairment, not on infectious condition.

One of the earliest cases involving mandated isolation of an individual known to be a chronic typhoid carrier involved a cook named Mary Mallon in New York in the early 1900's. After it was determined that Mallon was the common link to many incidences of typhoid outbreak, New York City health officials isolated her from the community by requiring her to be institutionalized. Mallon sought legal redress from 1907 to 1910, but the New York Supreme Court upheld the right of the community to keep her isolated. However, Mallon was released in 1910 and immediately disappeared. During the next few years the number of typhoid fever cases dramatically increased and eventually Mallon spent most of her later years in isolation on a voluntary basis (Oregon State Board of Health 1969).

More recently, another case based on an infectious condition was $\underline{\text { School }}$ Board of Nassau County v. Arline, 480 U.S. 273 (1987). This case presented the question of whether an individual afflicted with a contagious disease (tuberculosis) may be considered a "handicapped individual" as defined in Sec. 504 of the Rehabilitation Act, and if so, whether such an individual is "otherwise" qualified to teach elementary school. Gene Arline was discharged in 1979 after she suffered a third relapse of tuberculosis within two years. She brought suit in the federal court after she was denied relief in state administrative proceedings. The District Court held that while there was no question that Arline suffered a handicap, she was nevertheless not handicapped under the terms of the statute. It went on to state that even if a person with a contagious disease could be deemed handicapped, Arline was not "qualified" to teach elementary school. The Court of Appeals reversed the District Court's decision and remanded the case for further findings. This case went on to the Supreme Court wherein Justice Brennan wrote an opinion that concluded 
that even those individuals who had a contagious disease and who might pose a serious health threat to others could not be excluded coverage under Section 504 of the Act which was meant to ensure that handicapped individuals were not denied jobs or other benefits because of ignorance or prejudicial attitudes of others. The opinion further agreed with the Court of Appeals that due to the lack of substantial factual findings by the District Court, it was unable to resolve whether or not Gene Arline was "otherwise qualified" for her job. On remand, the trial court determined that Arline was entitled to reinstatement as an elementary teacher. [See Arline v. School Board of Nassau County, 692 F.Supp. 1286 (M.S. Fla. 1988).]

The first significant federal appellate ruling directly related to AIDS-related discrimination under the Rehabilitation Act was decided on behalf of a public school teacher with AIDS. In February of 1987, Vincent L. Chalk, a certified teacher of hearing-impaired students in the Orange County California Department of Education, was diagnosed as having AIDS. The Department, upon learning of Chalk's medical condition, reassigned him to an administrative position and barred him from classroom teaching. Chalk then brought an action in the District Court in which he claimed that the Department had violated Sec. 504 of the Rehabilitation Act of 1973. When the District Court denied his motion for a preliminary injunction ordering his reinstatement, Chalk filed an appeal. In the case Chalk v. U.S. District Court for the Central District of California, 840 F.2d 701 (9th Cir. 1988), the 9th Circuit Appellate Court found that there was no evidence that Chalk was a significant risk to children or others at the school so the District Court should not have denied injunctive relief. The Court of Appeals relied on the School Board of Nassau County v. Arline and New York State Ass'n of Retarded Children v. Carey decisions to help support its position that the purpose of Section 504 of the Rehabilitation Act was to ensure that handicapped individuals are given opportunities 
and not denied jobs or other benefits. The school administrators of the District decided not to pursue the case any further and restored Vincent Chalk to his teaching position.

The Office of Civil Rights of the U.S. Department of Health and Human Services began receiving AIDS-related discrimination complaints as early as 1984. Up to then, discrimination claims involving contagious conditions were unprecedented and the Office of Civil Rights was uncertain how to proceed. It requested from the Department of Justice an interpretation of Section 504 of the Rehabilitation Act of 1973. In 1986 while the case School Board of Nassau County v. Arline, 107 S.Ct. 1123 (1987) was being decided by the Supreme Court, the Justice Department issued an advisory memorandum setting forth an analysis which was subsequently rejected by the Supreme Court. That analysis concluded that discrimination against persons with contagious conditions would not violate Section 504 of the Rehabilitation Act as the discrimination was motivated by fear of contagion. After the Arline decision, Congress responded by amending the Rehabilitation Act to incorporate the position taken by the Supreme Court by including language to include those individual who are "perceived" or are "regarded as" being a threat (Closen et al. 1989, pp. 271-77).

The President's Commission on the HIV Epidemic subsequently issued its final report recommending the passage of federal anti-discrimination legislation to protect persons infected with the HIV, and the Department of Justice rendered a new opinion at the request of the Counsel to the President. Douglas W. Kamiec, Acting Assistant Attorney General of the Office of Legal Counsel wrote a memorandum to Arthur B. Culvahouse, Jr., Counsel to the President on September 27, 1988 which read in part: 
[We] have concluded, with respect to the non-employment context, that Section 504 protects symptomatic and asymptomatic HIV-infected individuals against discrimination in any covered program or activity on the basis of any actual, past or perceived effect of HIV infection that substantially limits any major life activity -- so long as the HIVinfected individual is "otherwise qualified" to participate in the program or activity, as determined under the "otherwise qualified" standard set forth in Arline. We have further concluded that Section 504 is similarly applicable in the employment context, except for the fact that the Civil Rights Restoration Act replaced the Arline "otherwise qualified" standard with a slightly different statutory formulation. We believe this formulation leads to a result substantively identical to that reached in the non-employment context: namely, that an HIV-infected individual is only protected against discrimination if he or she is able to perform the duties of the job and does not constitute a direct threat to the health or safety of others. (Closen et al. 1989, p. 285).

In March 1988, the U.S. Office of Personnel Management issued guidelines for federal agency employers concerning AIDS in the workplace. The gist of these guidelines can be obtained from the following excerpt of the Guidelines as reported in the Bureau of National Affairs Daily Labor Report No. 56 on March 23, 1988:

Guidelines issued by the Public Health Service's Centers for Disease Control (CDC) dealing with AIDS in the workplace state that "the kind of nonsexual person-to-person contact that generally occurs among workers and clients or customers in the workplace does not pose a risk for transmission of [AIDS]." Therefore, HIV-infected employees should be allowed to continue working as long as they are able to maintain acceptable performance and do not pose a safety or health threat to themselves or others in the workplace. (Closen et al. 1989 , p. 285).

On July 13, 1990 The Americans with Disabilities Act (ADA) was passed by Congress and subsequently signed by President George Bush. The Act will become effective on July 26, 1992. Several sections of the Act specifically address employment discrimination and by definition include protecting the HIV infected individuals.

In looking at the HIV or AIDS related employment discrimination, disability discrimination statutes are the most likely to impact employment decisions. While the Employee Retirement Income Security Act of 1974 (ERISA) generally applies to 
all employee benefit plans which are maintained by employers in the private sector (e.g., pension, life insurance, and medical benefits), specific sections may prove important in dealing with AIDS-related issues in the employment/business arena. Section 510 of ERISA prohibits an employer from discriminating against, discharging or interfering with an employee's rights to exercise an opportunity to receive any benefits otherwise available to him or her. Therefore, an employer may not discharge an employee who has applied for benefits as a result of his or her HIV positive or AIDS status, or prevent him or her from applying for benefits in the future. While the number of times Section 510 has been challenged is few, when tested the federal courts have found such firings to prevent future claims for medical benefits unlawful (Leonard 1987, p. 118).

Business/employment discrimination matters are taken up not only in the federal but also in the state courts. There are no general or standard guidelines used, however, and the actual court ruling is based upon the court's interpretation of the law and the facts of the individual case at issue. Overall, when these courts are confronted with factually clear cases of discrimination based on the HIV positive status, active AIDS standing, or fear that an individual may belong to a high risk group, legal redress to the individual being discriminated against by the employer is provided. A majority of the early cases involving business/employment issues with regard to individuals with the HIV or AIDS resulted in challenges to existing laws, federal acts, regulations, SOPs, and as defined in this thesis are seen as resulting in a moral boundary construction. However, as these initial challenges have been resolved by the state and federal court systems, fewer cases are being filed involving issues not previously dealt with. Those cases that are currently being judicially decided are bringing about fewer changes to existing laws and are therefore seen as 
moral boundary maintaining (in that any challenge to existing laws is denied) rather than boundary construction.

\section{Access to Education}

Another highly emotional area of concern regarding the HIV and AIDS surrounds the issue of who has the right of access to public education. This is particularly true when young children are the ones with the HIV or AIDS. AIDS was reported among children soon after the disease was identified and thus became an issue which demanded action by persons holding two extremely different points of view. On one side were those individuals who felt there was a right of all children, even those with the HIV or AIDS, to have equal and unrestricted access to public education, while on the other there were those who believed uninfected children had the right to obtain education in a safe and non-threatening environment separate from those with the capacity of spreading a contagious and fatal disease.

Parents, teachers and school administrators even in 1991 have made demands of the educational system to remove an infected child from the public school environment if there were any risk whatsoever that other children may become infected. While most of the risks are in fact minor, the fear that is generated is real and often brings about real consequences. Such was the case with Ryan White who was denied admission to school in Indiana. After being threatened and fearing for their lives as a result of adverse public reaction when they pursued Ryan's admittance to public school, the Whites moved to another city. Likewise, the Ray family after being burned out of their home when it was learned that their elementary age school children were HIV positive, not only felt threatened but experienced random acts of violence (Schmalz 1988). 
While public education is not a fundamental right granted by the Unil States Constitution, once education was established as a public entitlement, the right of a child to attend public school was subject to reasonable regulation by the federal government. In addition, the Supreme Court has recognized the value of education through several Supreme Court decisions upholding public education financing and student rights regarding disciplinary actions. In order to have the Supreme Court review a case, there must be a constitutional issue involved, and it is first necessary to establish that there is state action in order to determine whether or not a constitutional argument can be raised. With regard to education, state action can be established by looking at the exclusionary practices of the school system of state and local educational agencies which provide education to citizens. After state action has been established, a determination must be made whether or not a constitutional right has been denied. With regard to education, the Fifth and Fourteenth Amendments are most often relied upon. These two amendments provide in part that no state shall deny persons equal protection of the law, nor may they deprive persons of life, liberty, or property without due process (Closen et al. 1989, p. 341; Kass 1987, p. 74).

The question of whether children infected with the HIV or AIDS should be allowed to have the same access to public education as those uninfected arises out of legislation surrounding school children and infectious diseases. The case of New York State v. Carey, supra is relied on as being the foundation of the rights of those considered handicapped through infectious disease, or physical or mental impairment. In 1979, Judge Jon O. Newman in his opinion relied on the Rehabilitation Act of 1973 which provides in Section 504 that 
No otherwise qualified handicapped individual in the United States, as defined in Section 706(7) of this title, shall, solely by reason of his handicap, be excluded from the participation in, be denied the benefits of, or be subjected to discrimination under any program or activity receiving Federal financial assistance or under any program or activity conducted by any executive agency ....

The judge reasoned that since the New York City Board of Education received federal assistance, and that the children in the lawsuit were clearly handicapped as defined by Section 706(7) of the Act, they were entitled to public education.

In the case Brown v. Board of Education of Topeka, 347 U.S. 483 (1954), the Supreme Court held that when a state provides education, education must be provided on an equal basis. Since every state in the United States provides education to its citizens, each state is also subject to the findings set forth in the Brown case (Closen et al. 1989, p. 341).

In Plyler v. Doe, 457 U.S. 202 (1982), (another leading Supreme Court case), the Court overruled a Texas statute which allowed school authorities to refuse to enroll children of illegal aliens in public school. Its decision was based in part on the fact that Texas law violated the equal protection clause of the Fourteenth Amendment. Even though education is not a fundamental right, once a state provides it, it must do so equally to all students. The Court went on to indicate that public education was the primary means by which a child learns the values and political structure of the society, thereby possibly hinting that perhaps public education does constitute a fundamental right (Sloan 1988, p. 56).

One of the main issues surrounding whether or not children with the HIV or AIDS should be afforded education in public schools is determining whether or not they are considered handicapped as defined by state and federal laws. There are several ways a child may be determined to be handicapped. The federal Education 
of All Handicapped Children Act (EAHCA) lists handicapping conditions and notes that children fall within the protection of this Act if "by reason of the condition the child requires special education and related services." 20 U.S.C. Section 1401(1)(1982) (Closen et al. 1989, p. 354). Some children (especially those with the HIV) may have no special educational needs, while those with AIDS may be homebound and need special services such as home instruction. Other children may be seen as falling within the protection of Section 504 of the Rehabilitation Act which regards them as having an impairment such as that outlined in School Board v. Arline, 107 S.Ct. 1123 (1987), and therefore a case-by-case approach to assessing whether there is a transmission risk involved to other school age children is considered appropriate.

One of the initial reports of children with the HIV or AIDS occurred when the New York City Department of Health received its first letter in the Spring of 1983 from a school requesting information on how to deal with a child infected with AIDS or an AIDS-related illness. In that there was no official policy at that time, the Health Department responded by providing the guidelines and precautions recommended for dealing with children who were hepatitis B carriers. It was not until late 1984 and early 1985 that school officials began to formulate a policy which would deal specifically with children infected with the HIV or AIDS. In June of 1985 , the CDC held a meeting looking specifically at issues raised by the presence of children with the HIV or AIDS in the classroom. The guidelines were compiled following extensive input from epidemiologists, state and county health officials, school officials and representatives of parent and child welfare organizations. The result was an advisory report published by the CDC on August 30, 1985 in the Morbidity and Mortality Weekly Report which outlined information and detailed recommendations concerning the education, day care and foster care of these 
children. The gist of the recommendation was that school aged children infected with HIV be allowed to obtain their education in a classroom setting without restrictions unless they were neurologically impaired or lacked the ability to control their body secretions or if they were unable to physically control certain behavior such as biting. While the CDC guidelines are advisory and not federally mandated, they have been relied on and used as a model by policymakers since they were published (Schwarz and Schaffer 1985, pp. 163-65; Kass 1987, p. 69).

Shortly after the CDC's August 30, 1985 publication, many cities, particularly those already in positions of having to deal with infected children, adopted the CDC's recommendations. On August 30, 1985, the same day CDC published its guidelines in Morbidity and Mortality Weekly Report, New York City adopted a majority of the CDC's policies in that the schools would not be allowed to automatically exclude children with AIDS from having access to public education. New York City schools would be required to treat each child on a case-by-case basis. It also formed a panel to review the children currently in the public education system and to evaluate whether it was in their best interest to attend public school in an unrestricted manner (Schwarz and Schaffer 1985, p. 165).

Even with the CDC's recommendation, the issue of whether or not children with the HIV or AIDS should be taught in the same environment as children who did not have the HIV or AIDS had become a hot issue for many school districts. In response to what appeared to be public pressure, two community school boards in Queens, New York passed resolutions on August 27, 1985 that prevented children who had AIDS, or who resided in a house with someone who had AIDS, from attending public school within their school district.

New York announced its policy of nonautomatic exclusion on August 30, 1985 which thus placed the two school districts who had just passed an AIDS 
restriction in violation of city policy. While the CDC recommended a case-by-case review of children with the HIV or AIDS, the New York City Health Commissioner adopted a similar case-by-case review but only for those children of school age with AIDS, not the HIV or other illnesses associated with AIDS. The panel formed by New York City School Board to review all the HIV positive or AIDS children identified seven children in New York City, all under eight years of age, reported as having AIDS. Due to family relocation outside of New York City of three of the children, and hospitalization of two others, only two infected children were determined to be physically and emotionally capable of attending school. However, because the identity of one of the two infected children had been disclosed, the parents were encouraged to seek "alternate educational opportunities" to discourage any discriminatory acts that might occur. The panel decided that the remaining child should be allowed to attend public school. Some parents in the two districts organized a school boycott in which 9,000 to 11,000 school-age children stayed away from school, and when school opened on September 9, 1985 a lawsuit was filed (District 27 Community School Board v. Board of Education of the City of New York, 130 Misc. 2d 398, 502 N.Y.S.2d 325 [Sup. Ct. 1986]), which sought to prohibit the child with AIDS from attending public school, or in the alternative, to identify the child to the school board members and school officials. After a monthlong trial, the Supreme Court of Queens County upheld the New York City policy of not automatically excluding children with AIDS from access to public education. The decision also pointed out that since there was overwhelming evidence that AIDS was not transmissible solely by individuals being in a classroom environment, excluding children with the disease from school would also violate the Federal Rehabilitation Act of 1973 which includes the right "to equal protection of the laws." (Schwarz and Schaffer 1985, pp. 166-67; Kass 1987, pp. 72-73). 
The decision obtained in District 27, while not a federal court ruling, is considered by many as the first in the United States to look specifically, and with such depth, at the legal and factual issues surrounding children with the HIV or AIDS and their rights to have the same access to public education as noninfected children. The court in issuing its decision relied on prior federal decisions (e.g. New York State Association for Retarded Children, Inc. v. Carey, 612 F.2d 644 [2d Cir. 1979]) in that excluding children with AIDS from school would also violate the Rehabilitation Act of 1973.

The case of White v. Western School Corp., No. IP-85-1192-C (S.D. Ind. Aug. 16, 1985), asked the court to interpret the federal statute Education of All Handicapped Children Act (EAHCA) which refers to the admissibility of infected children to public schools. Ryan White was a hemophiliac who had contracted AIDS through blood transfusions. Even though the Indiana Guidelines for Children with AIDS/ARC Attending School concluded that such children be allowed to attend public school, the superintendent of schools prohibited Ryan White from attending middle school. Ryan and his mother brought a lawsuit against the school board charging that the board's actions were unlawful discrimination under the EAHCA. The federal district court agreed with the school board's arguments that Ryan White must first take his case through the state administrative process before taking his case to court. Ryan White did so and presented his case to the appropriate Indiana officials who concluded after extensive hearings as to White's educational needs and the epidemiology of AIDS, that he could attend public school. On February 13, 1986, Ryan White was issued a health certificate by the county health officer which documented that he should be permitted to attend public school. However, a group of parents petitioned a local county court for an order barring White from attending public school because he had a communicable disease and thus was prohibited from 
attending school according to Indiana health regulations. The order was granted and Ryan White was barred from attending public school. Shortly thereafter, Ryan and his mother were successful in having the case transferred to a neighboring jurisdiction where they had moved and the order was reversed. The court reasoned that Indiana health regulations had to be read in conjunction with state regulations that children with a health certificate be allowed admission to school. Ryan White began middle school in the neighboring county on August 25, 1986 (Kass 1987, pp. 76-77). Ryan White was allowed to attend school and did so until his death on April 8, 1990. Ryan White and his fight with the state of Indiana for the right to attend public school was one of the most nationally publicized and followed cases of an AIDS infected child's access to public education.

Even though there is no federal policy governing how individual states deal with issues surrounding children infected with the HIV or AIDS, the rights these infected children have to public education can be associated with many federal acts and court decisions. Given this federal support, many individual states and local school boards are learning to adjust to the legal guarantees afforded to not only the physical but emotional needs of school children infected with the HIV and AIDS.

At least one state, Illinois, has assembled a task force of state public health and school officials to develop recommendations for administration of chronic infectious diseases such as the HIV within the public school environment (Closen et al. 1990, p. 89). The focal point of the task force is to come up with a management plan which will meet the needs of all children. In 1989 the task force issued a report which followed the CDC's recommendation that the HIV infected children not be automatically excluded from unrestricted classroom settings and that they (1) be individually evaluated to determine if public education will meet the child's needs while at the same time posing no danger for other children, and (2) as a result of the 
evaluation develop an educational plan for the infected child. The task force views confidentiality of student records as their chief concern and because of state laws which regulate who may or may not be told of an individual's HIV or AIDS status, some Illinois schools have chosen to separate the school records of infected children from uninfected children thereby reducing the access to such information and increasing the child's right to privacy (Closen et al. 1990, p. 89). The mere act of separating records, however, identifies those students with the HIV or AIDS.

For the most part, courts have generally upheld interpretations of existing civil rights laws which prohibit disability-based discrimination to include the HIV positive persons in business/employment and education access cases.

As with the law suits involving business/employment, most of the early cases filed with regard to access to education involved individual rights of those with the HIV or AIDS. These legal issues involved in many of these early cases challenged existing laws, federal acts, regulations, policies. Many of these early legal decisions also resulted in changes in current laws, and as defined in this thesis are seen as resulting in a moral boundary construction. However, as these initial challenges have been resolved by the state and federal court systems, fewer cases are being filed involving new issues.

\section{Medical Care Delivery}

Of the social institutions business/employment, education and medical care, medical care is by far the one most thoroughly regulated and monitored by the federal government. Of the three mentioned social institutions, health care has most frequently generated emotional reactions from individuals since the HIV/AIDS was first recognized. It is also an area which up until recently has tried to remain neutral on mandating policy procedures regarding the HIV/AIDS. Issues such as 
mandatory testing, confidentiality of medical testing and diagnosis, and disclosure of the HIV status between medical care provider and patient all deal with fundamental constitutional rights such as equal protection and due process.

Initially the issues confronting the medical care industry centered around the dilemma of whether or not there was a legal duty on the part of medical care providers to treat the HIV positive or AIDS infected individuals. Next, the focus expanded to include the safety of the blood supply, and in particular the procedures and practices followed by the American Red Cross in its screening of potential donors and the testing conducted on blood collected and distributed. More recently, the medical care institution has been faced with responding to issues involving rights of disclosure and mandatory testing in the patient/provider relationship.

The issue of whether medical care professionals are obligated to treat all patients also finds its foundation firmly planted in the Civil Rights Act of 1964. On June 29, 1968, the Attorney General, on behalf of the United States, filed a suit United States v. Medical Society of South Carolina, 298 F.Supp 145 (D.S.C. 1969) in order to restrain the defendants from operating Roper Hospital in Charleston, South Carolina on a racially segregated basis. Plaintiff relied on Titles II and VII of the Civil Rights Act of 1964, 42 U.S.C. Sections 2000a and 2000e. The Court determined that discrimination based on race was in violation of the Act and that the rights of Negroes to admission and equal employment opportunities at Roper Hospital were protected by 42 U.S.C. Sections 1981 and 1982. It further ordered Roper Hospital to eliminate race or color as a factor in determining admission, assignment to floors, and in its operation of all programs it sponsored or conducted (Closen et al. 1989, pp. 597-99). While this particular case was based and brought on behalf of racial discrimination, it can also be easily applied to the HIV positive 
or AIDS victims who are by reasons of their disease identified as individuals sharing traits not common among the dominant members of society.

Until recently the fear of AIDS within the medical community was not serious because most of the initial AIDS cases were diagnosed within established gay communities. Initially the primary health care providers were those physicians already closely identified with the gay community, although there were a number of other physicians who also felt ethically bound and so did treat AIDS patients. It was not until large numbers of individuals became identified as having the HIV or AIDS, along with the spread of the disease outside of the specific groups identified as high risk, that some members of the general medical community became reluctant and sometimes refused to treat the HIV positive or AIDS patients. Cases brought with respect to the duty of physicians to treat the HIV positive or AIDS patients are often first brought before the Commission on Human Rights which hears complaints involving the medical profession of the state where the action occurred. These matters are often decided at this level, and if not, most often are decided in the state court system.

Probably the most publicized health care provider transmitted AIDS case is the one involving a dentist and one of his young patients. This case involved a dentist in Stuart, Florida, who had AIDS and continued to practice without disclosing this medical condition to his patients, or adopting practices which would have reduced the risk of transmission. Shortly after his death due to AIDS complications, Dr. David Acer's estate had published in the local newspaper a letter Acer had written to his former patients advising them of his medical condition. One of his former patients, Kimberly Bergalis, filed a lawsuit against the dentist's estate in September 1990. It was determined through CDC testing that she had a strain of HIV closely matching one cultured from Acer. This similarity of virus strains 
raised the possibility of the patient contracting the virus while obtaining dental treatment (Applebome, 1990; Newsweek 1990, p. 80). A \$1 million settlement was reached the latter part of January, 1991 between Bergalis and the estate of her former dentist Acer (Leinwand 1991). On February 14, 1991, less than two weeks after disclosure of the $\$ 1$ million settlement between Bergalis and the Estate of Acer, a second dental patient of Acer filed his own $\$ 1$ million lawsuit. As was the case with Bergalis, the CDC found through DNA sequencing tests a $99.94 \%$ probability that Acer also infected this dental patient, Richard Lee Driskill (The Oregonian 1991). The question medical patients pose (particularly those dental patients who have filed lawsuits) is what should the requirements of disclosure be with regard to medical services, not only on the part of the patient but also of the provider.

There have also been several verdicts within the last year that have awarded large sums of money to individuals infected with AIDS through infected blood transfusions. Most of these lawsuits have been directed toward blood collection agencies for failing to properly screen potential donors and/or to properly screen donors. In Columbus, Ohio a woman was awarded $\$ 12$ million; in Denver, Colorado a woman received $\$ 5.5$ million; in Milwaukee, Wisconsin a man was awarded \$3.9 million (Marcotte, 1990); and in Seattle, Washington a woman was awarded \$1.8 million (The Oregonian, 1990). Several of these awards have subsequently been negotiated by the parties and the cases settled for undisclosed amounts in settlement prior to the matter entering the appellate stage of the judicial process.

Cases involving medical care delivery are continuing to be filed and decided. There have been many challenges to existing laws, policies, and procedures which can be viewed as constituting moral boundary construction activity. However, there are no precedent setting cases which have reduced the number of lawsuits being 
filed. As a result, the moral boundary profile with regard to medical care delivery is still being defined. The time involved in this defining process appears to be more complicated than that of business/employment or access to education. It would be difficult to estimate how long it will be before there is a shift from moral boundary construction to moral boundary maintenance activity.

The first decade of AIDS can be identified as one full of uncertainty as to the epidemiology and etiology of the AIDS epidemic. While the second decade of AIDS has just begun, it already can be identified as one rife with uncertainties as to what procedures to follow in dealing with individuals diagnosed as either HIV positive or with AIDS. 


\section{CHAPTER IV}

\section{SUMMARY AND CONCLUSION}

It is safe to say that the relationship between law and society is complex and dynamic. This relationship can be viewed as involving various forms of causality: (1) legal change leading to social change; (2) social change leading to legal change; or (3) an interdependent interaction between social change and legal change. As a social mechanism the legal system is often thought to provide protection for the individual from the public while at the same time protecting the public from the individual. The ultimate goal is to mesh these two objectives so that both individuals and society as a whole are treated as morally and ethically equal.

\section{SUMMARY OF THEORETICAL FRAMEWORK}

One of the enduring questions regarding the relationship between law and society is whether law is a reflection of the nature of a society, or whether society is regulated by law. Many early theorists such as Marx, Weber and Durkheim viewed the causal link between law and society as uni-directional. Some of these early theorists believed that social change leads to legal change, while others believed that legal change leads to social change.

It was Marx who suggested that law was passive and society was active. In addition, he believed that changes in de jure social rules are reflective of society's economic base (Phillips 1980, pp. 199-201). According to Weber, the relationship between law and society could be found by looking at various aspects of law making and law finding. Weber's definition of law as "a system of norms which are 
guaranteed by legal coercion" is considered to be a useful and operational definition of law (Simon 1968; Selznick 1979). It was Durkheim, however, who stressed the use of scientific methods for studying social facts which arise from social phenomena. To this end, Durkheim viewed laws as an external index by which values and morals of society can be examined. By examining the legal codes of society, Durkheim believed it was possible to understand the relationship between the individual and society and what he termed social solidarity. In his examination of the relationship between law and society, Holmes believed that as attitudes and beliefs regarding acceptable and unacceptable practices within a community shift, laws are likewise susceptible to changes so that they are in line with the moral beliefs and practices of society. In addition, Holmes suggested that the laws enacted at one point are not necessarily the laws that will be logical or appropriate at another (Holmes 1968, pp. 20-26).

These classical theorists provided the guidelines for examining the relationship between law and society as reflected by the legislative activity that has occurred around the AIDS epidemic since 1980. Specific guidelines include: examining the various aspects of law making and law finding and the interaction that occurs; defining law in operational terms; using scientific methods to study the relationship; and recognizing that laws change with time.

Several contemporary theorists such as Selznick, Luhmann and Schur, however, view the relationship between law and society as an interactive one, each dependent on the other in a constantly changing and evolving process. The causal relationship between society and law, according to these theorists, is based on a developmental process wherein the understanding is that the law is the law of society and changes as societal changes occur. 
These contemporary theorists have added to an understanding of the relationship between law and society which proved to be useful in looking at the legislative activity which has occurred in the United States in response to the AIDS epidemic. Erickson looked specifically at social boundaries and the role deviation from established laws plays in defining or maintaining a boundary. This viewpoint is valuable in trying to understand why there was very little initial legislative response to the AIDS epidemic.

Both Selznick and Luhmann point out that the relationship between society and law is so interdependent that rather than a change in society leading to change in laws, or a change in laws leading to a change in society, law and society change with each other. Given the volume of legislative activity generated by federal, state and local governmental agencies in the short time since AIDS has become recognized as a communicable disease, this approach is useful for understanding the nature of the relationship between law and society in response to the AIDS epidemic. For instance, changes occurring in society as a result of the AIDS epidemic are generating a plethora of legislative activity. Not all of this activity, however, ends up being law.

In their definitions of law, Kelsen and Ehrlich present the view that laws decree negative sanctions or compulsory orders to keep individuals within a desired or acceptable moral boundary. This approach is particularly useful when the content of the many proposed and enacted laws is examined. Many of these laws prohibit certain conduct, require that specific procedures be followed, or monitor an individual's activities and behaviors.

Cowan and Quinney each look at groups and how their organized efforts are often more successful than individual efforts in bringing about changes in the social order. This is exemplified by the current enactment of laws relating to the HIV 
positive persons and AIDS patients. In particular, the laws pertaining to the health care profession have been greatly impacted during the last 10 years.

Nader and Serber, and Chambliss and Seidman present the position that in a centralized State where key individuals or groups are in positions of authority, one part of society is able to keep another subordinate to the dominant group's values and interests. It can easily be argued that much of the proposed and recently passed legislation dealing with the HIV and AIDS is a direct consequence of particular groups in positions of power and authority. Illustrative of this are, for example, the following: the amount of funds allocated to AIDS research has fluctuated over the years; the federal government has changed its position on immigration by first adding AIDS to the list of conditions that may exclude immigrants, then removing this automatic elimination, and finally reinstating the condition of AIDS as being a possible exclusion; and proposed amendments to the social security entitlement programs as AIDS is added to the list of compensable disabilities.

Finally, Akers discusses how efforts to answer questions regarding social labels of "deviance" center around three interrelated phases of one process. These phases include: (1) the establishment of social norms of correct or expected behavior; (2) deviation from those expectations; and (3) reactions of others to such deviation. Societal responses to the AIDS epidemic readily fit into Akers three phases. Initially there was an established set of social norms (existing laws). Individuals infected with the HIV and AIDS were seen as deviating from these norms in that they were viewed as being capable of spreading the deadly disease. The laws in effect at the beginning of 1981 failed to satisfactorily deal with these "deviant" cases as AIDS was an unanticipated social phenomenon. The subsequent reactions can be found not only in the modification of existing laws and introduction of new ones, but also in the way social institutions are now interacting. 


\section{SUMMARY OF METHODOLOGY}

How the relationship between law and society influences moral boundaries is one of the concerns in this thesis. As indicated above, the abstract concept of moral boundaries is evidenced by the laws of a given society. In particular, this thesis has focused on the changes in American jurisprudence in the areas of business/ employment, access to education and medical care delivery in response to the AIDS epidemic since 1980, and how these legal changes may have and currently are modifying American moral boundaries.

These three social institutions were selected to represent the varying degrees of governmental control through regulations and laws, and various aspects of social life which are highly emotional and likely to be reported by the mass media. The moral boundaries of business/employment, access to education, and medical care delivery were examined to see if there had been any modifications resulting from the impact of the AIDS epidemic, or if the original boundaries had been maintained. Therefore, a longitudinal approach was selected to compare the laws in place prior to the identification of AIDS as a specific social phenomenon, with those laws that emerged thereafter.

Content analysis was utilized in order that written communication of a qualitative nature could be quantitatively coded in a systematic and objective manner. Given the fact that most laws, legal opinions, procedures, guidelines, and forms of mass media involve written communication, content analysis was the most useful methodology.

While media exposure has not been defined as contributing to the construction or modification of social moral boundaries, it does greatly influence an individual's beliefs and thus his or her moral principles and values. This has been 
particularly true with regard to how individuals have come to be informed about issues regarding the AIDS epidemic. While the media does not actively participate in the law making process, it does directly influence and affect those individuals who are part of the process.

Therefore, newspaper articles were selected as a social indicator of topics seen as being socially important. As a comparative tool, newspaper articles dealing with AIDS since 1981 from one national (The New York Times Index) and one regional (Newspaper Index [NPI] included The Oregonian, Willamette Week, and The Business Journal) publication were selected. Each of the newspaper articles indexed was read in order to determine whether it dealt with business/employment, access to education, or medical care delivery. Once classified as dealing with one of the three institutions of interest, the summaries were reread in order to determine whether it dealt with personal or public rights issues, and whether or not it dealt with boundary construction or maintenance. A newspaper article was seen as dealing with boundary construction if it incorporated key words in the summaries which dealt with challenges to existing laws or practices, and was seen as boundary maintenance if no such key words were identified. Of the 3,905 articles indexed in The New York Times Index, each was read and 731 were identified with one of the three institutions. Of the 371 articles indexed in NPI, 113 were identified with one of the three institutions.

In considering the three institutions, a similar methodological approach was then taken in looking at the legal decisions in the United States federal court and state court systems relating to the AIDS epidemic since 1981. Of the 322 federal court decisions, 124 related to one of the three institutions, and of the 270 state court decisions, 92 related to one of the three institutions. As with the newspaper articles, each of the legal decisions was then read to determine whether it dealt with 
personal or public rights issues, and whether it could be classified as boundary construction or maintenance. Legal decisions were seen as relating to boundary construction if there was some aspect of the decision which altered existing laws or required the court to re-examine certain issues in the lawsuit. Legal decisions were seen as relating to boundary maintenance if the decisions dismissed the challenges presented and no changes were made in any of the existing laws.

\section{SUMMARY OF ANALYSIS}

An analysis of the data presented in Chapter III suggests that the causal relationship between social change and legal change is in fact interactive. Interaction is operationally defined by analyzing the fluctuation of social change (represented by national and local/regional newspaper articles) and legal change (represented by federal and state court legal decisions). By looking at the number and frequency of 846 newspaper articles and 216 lawsuits filed in the areas of business/employment, access to education and medical care delivery from January of 1981 through December of 1991, this interactive process is illustrated.

An analysis of the data in Tables IV and VI illustrate the amount of moral boundary construction and maintenance which has occurred for the three institutions combined. While there has been more emphasis on boundary maintenance than on construction, this difference may disappear as challenges in the area of medical care delivery are resolved.

For instance, in the area of business/employment, there were more newspaper articles appearing during the mid to late 1980's than there have been since 1990 . While the number of legal decisions appears to be slightly increasing, it must be remembered that legal cases may take two to four years to get to the appellate stage so that in fact these lawsuits were probably originally filed during the 
mid to late 1980 's. While the number of cases reported in 1991 is slightly larger than during the 1980's, the total number of cases fluctuates between 3 as the low and 6 as the high per year. This variance between the high and low is relatively minor in proportion to the number of lawsuits, for instance, filed in other matters such as medical care delivery. It might well be that in subsequent years as laws affecting business/employment become enacted at all governmental levels, the number of lawsuits will diminish. While it currently appears that moral boundaries involving business/employment are still being redefined, it may be the case in the near future that this redefined moral boundary will find itself in a maintenance pattern, reflecting the interactive nature of the relationship between law and society. If a delay period is taken into consideration for legal decisions, social change (newspaper articles) and legal change (legal decisions) have similar peak and valley patterns for the same years. For example, there was a substantial increase in the number of newspaper articles dealing with business/employment that appeared during the years 1986 through 1989. In comparison, there was a marked increase in the number of legal decisions during the years 1989 through 1991 when the data collection ended.

In the area of access to education, the majority of newspaper article coverage and lawsuit activity occurred between the mid to late 1980's. A similar peak occurred with education as did with business/employment with regard to observing an interactive process. Illustrative of this, for example, was the rapid increase in the number of newspaper articles which occurred in the years 1985 through 1988. Accounting for a delay period, legal decisions which occurred during the years 1987 through 1989 relating to access to education mirrored a similar pattern. Since that time, however, the number of newspaper articles and lawsuits has decreased to almost zero. This seems to indicate that interaction occurred, and that the moral 
boundary in the sense of enacted laws and established regulations involving the issue of AIDS and access to education has, at least for the time being, stabilized and hence the number of challenges are few. How long this stabilization will be maintained, however, is questionable as new information about the HIV and AIDS is continually emerging.

Unlike business/employment and access to education, medical care delivery is currently experiencing its second wave in the interaction process. The first wave is represented by the emergence of newspaper articles (focusing largely on contaminated blood products) in the years 1983 through 1988, and by the number of legal decisions beginning in 1987 and continuing to escalate through 1991, the last year data was collected. There appears to be a second wave of social change occurring (suggested by analyzing the newspaper articles) beginning in 1991. Any reciprocal pattern, or interaction, involving a second wave of legal change will have to be analyzed from data collected during the next several years.

Currently, questions of disclosure and privacy are uppermost in the minds of those in the lawmaking process, as they are with those individuals who have the HIV or AIDS and those who do not. This interaction process between law and society is therefore currently taking place with regard to the area of medical care delivery. While social change is leading to legal changes, lawmakers are anticipating the needs of individuals and the public with regard to the Constitutional rights issues. In this respect, law and society are reacting in an interactive manner as described by Luhmann (1985), Selznick (1968) and Schur (1968). It appears that lawmakers are attempting to not only respond to the current needs of society as a result of the AIDS epidemic, but also to anticipate its future needs by enacting laws which incorporate insight as to societal and individual requirements. 


\section{SUMMARY OF ADDITIONAL QUESTIONS}

Additional questions as to the causal relationship between society and laws in response to the AIDS epidemic were identified in Chapter I as adding insight into this relationship. These questions are repeated below, followed by responses.

1. Given the dynamic nature of society, how are laws used to construct and maintain the moral boundaries of a society?

Laws appear to be enacted in order to codify the moral principles, values and beliefs that are widely accepted and established within society. These laws define what is socially acceptable and unacceptable behavior, and what positive and negative sanctions are permitted for those individuals who follow or deviate from them. Due to the dynamic nature of society, laws are modified in order to keep current with the times. However, due to the complexity of modifying established laws, this process can be extended long after it is needed. At times, it seems that laws only change because of pressure brought about by lawsuits and lobbying efforts. At others times, laws are changed because the behavior being addressed in previous laws is no longer relevant. As a result, moral boundaries, as the laws that define them, are dynamic. Increases in the number of social and legal challenges illustrate moral boundary construction efforts, while decreases portray boundary maintenance. Analysis of the data presented in Tables IV and VI suggest that as social challenges occur, legal challenges also occur, following similar peak and valley patterns. Again, a delay period should be taken into account when considering legal decisions as evidence of shifts in moral boundaries.

2. With regard to the AIDS epidemic, are laws and legislation in the United States merely a reflection of dominant social values, or instead, is society deterministically regulated by the law? 
As suggested earlier, the relationship between law and society is an interactive one. Existing laws of the early 1980's were challenged in the areas of business/employment, access to education and medical care delivery, thus giving rise to the notion that society regulates law. However, some of the modifications in the laws that have resulted (particularly with regard to access to education issues), have anticipated future legal challenges and can be viewed as law regulating society. This can be illustrated by looking at the area of access to education where during the mid to late 1980's there were many legal challenges and newspaper articles involving the issue of rights with respect to the AIDS epidemic. Since 1990, however, the number of newspaper articles and lawsuits have diminished. It is anticipated that this decrease will continue as moral boundaries, and the laws that define them, adjust to the needs of individuals and society with regard to the AIDS epidemic. Once most of the social and legal challenges have been suspended, a maintenance period for moral boundaries will follow. This phase will last only until some unanticipated aspect of AIDS arises and social and legal challenges once again result.

3. Have the enactments of laws led to the shift of moral boundaries, or rather, have the shifts in moral boundaries led to the enactments of laws?

As suggested in the answer to the above question, the enactment of laws and the shift in moral boundaries is an interactive process. While shifts in social moral principles, values and beliefs in response to the AIDS epidemic lead to challenges of established laws, it is also the case that modifications in laws redefine these adaptable moral boundaries. The suggestion that the relationship between law and society is interactive is illustrated by the analysis of the 846 newspaper articles and 216 legal decisions dealt with in this thesis. Stated briefly, those data indicate that 
law at times determines social policy while at other times is reflective of social change.

4. As both individuals and society bring up preservation of Constitutional rights issues, whose rights are being legislatively protected, and from whom or what?

The myriad lawsuits that have found their way into the judicial system illustrate the need of jurisprudence to answer the Constitutional rights issue. With regard to access to education, legal challenges in the mid to late 1980's found that the Constitutional rights of children to public education outweigh those often unfounded and misinformed concerns of society in general. With regard to business/employment, while some of the Constitutional rights issues have been addressed prohibiting employers from discriminating against individuals with the HIV or AIDS, legal challenges are still being decided by the judicial system on other issues such as insurance benefits and how long an individual with the HIV or AIDS is allowed to work before being terminated. By far, medical care delivery has been the area most heavily under attack on the issue of whose Constitutional rights are being protected, society or the individual. Initially questions as to the safety of the nation's blood supply were addressed. Not only were lawsuits filed by those individuals who suddenly found themselves infected with an incurable disease, but governmental agencies such as the FDA implemented strict guidelines for future blood handing practices. Recently, however, there has been a shift of Constitutional rights concern as individuals in general society are demanding to know if medical care providers are infected with the HIV or AIDS. Armed with this knowledge, individuals would then have the opportunity to make a choice whether or not to continue seeing the medical care provider. On the other side of the Constitutional rights issues, however, are those individuals infected with the HIV or AIDS who 
fear that their Constitutional rights will be denied if disclosure is mandated by law. The laws and thus the moral boundaries associated with the medical care delivery area are still in a great deal of flux. Instead of seeing a decrease in the number of newspaper articles and lawsuits being filed as with business/employment and access to education, there has instead been a dramatic increase since 1990 , indicating that both society and the law are still deciding how to deal with the area of medical care delivery in response to the AIDS epidemic.

5. What sort of legal demands and actions may arise when a person in one camp of the Constitutional rights dichotomy (individual versus society) suddenly finds that he or she is now in the other?

The ideal societal response to the AIDS epidemic with regard to the issue of balancing rights is to have laws enacted so that individuals who find themselves in each camp of the rights dilemma are protected. While this sounds like a relatively simple solution, finding the balance between the two sides of the dichotomy is much more difficult. One explanation as to why it seems to take so long for jurisprudence to respond to social and individual needs in response to the AIDS epidemic may be its desire to enact laws that will protect the rights of one side without infringing on the rights of the other. Thus, the status of the concerned individual remains in limbo while the legal construction of new boundaries is in process.

\section{SUMMARY OF ADDITIONAL LEGAL DECISIONS}

In addition to the number of legal decisions in the state and federal court system involving AIDS issues, there are a number of other cases and other forms of legislative and judicial history which have given rise to the notion of precedence and legal authority. While these cases, acts, Constitutional amendments, policies, and 
the like were not quantitatively analyzed, several of them were elaborated on in an effort to provide additional insight as to how future challenges to existing laws on AIDS issues will be addressed by the United States court system.

Given the highly emotional nature of the myriad issues involved in the AIDS epidemic, there may be no way to please everyone with regard to the whose rights are being protected. There may always be some individuals who see that their rights are being violated because they have the HIV or AIDS. Likewise, there may always be some who believe that their rights are being breached because they are not allowed to make decisions based on choice of associating with those with the HIV or AIDS.

\section{THOUGHTS FOR FUTURE RESEARCH}

Future studies as to the relationship between law and society may want to elaborate on the three social institutions focused on in this thesis, or possibly look at different social institutions such as family, religion, or sports. Another possible study would be a comparison changes in legal codes of different countries either taking a cross-sectional or longitudinal approach. Another possible approach would be to redefine moral boundaries to include what individuals of society believe to be important morals, values and beliefs. This information could quantitatively be obtained from social surveys of a specific geographic region.

\section{CONCLUSION}

As mentioned previously, the relationship between law and society is intricate. So too is the nature of the relationship between moral boundaries (a consensus of norms, values and mores) and de jure rules of acceptable behavior created and maintained by a society. With regard to the United States and the AIDS 
epidemic, one thing is almost certain. The moral boundaries as defined by the laws of American society will continue to be modified as the legal system continues to explore how to deal with the ongoing challenges of those members of society who have the HIV or AIDS. 


\section{REFERENCES}

Akers, Ronald L. 1985. Deviant Behavior: A Social Learning Approach. 3rd ed. Belmont, CA: Wadsworth.

Altheide, David L. 1985. Media Power. Beverly Hills, CA: SAGE.

Altman, Dennis. 1986. AIDS in the Mind of America. New York, NY: Anchor Press.

Angell, Marcia. 1991. "A Dual Approach to the AIDS Epidemic." N Eng J Med. May 23:1489-1500.

Applebome, Peter. 1990. "After Dentist's AIDS Death, Florida City is Sad but Uneasy." The New York Times. September 8:1+.

Bartlett, John G. 1988. "Testing for HIV Infection: Recommendations for Surgeons." American College of Surgeons Bulletin 73:4-10.

Beamish, Rita. 1990. "New Provisions Revitalize U.S. Immigration Law." The Oregonian. November 30, morning ed.:A22.

Berger, Peter L. and Thomas Luckmann. 1967. The Social Construction of Reality: A Treatise in the Sociology of Knowledge. New York, NY: Anchor Books.

Bohannan, Paul. 1979. "Law and Legal Institutions." Pp. 73-78 in International Encyclopedia of the Social Sciences, edited by D. L. Sills. New York, NY: MacMillan.

CDC (Centers for Disease Control). 1981. "Pneumocystis Pneumonia -- Los Angeles." Morbidity and Mortality Weekly Report 30:250-52.

---- 1987. "Public Health Service Guidelines for Counseling and Antibody Testing to Prevent HIV Infection and AIDS." Morbidity and Mortality Weekly Report 36:509-515.

----- 1991. "The HIV/AIDS Epidemic: The First 10 Years." Morbidity and Mortality Weekly Report 40:357-69.

Cecil, Andrew R. 1983. "Natural Justice and Natural Rights." Pp. 43-82 in The Search for Justice, edited by W. L. Taitte. Austin, TX: University of Texas Press.

Chambliss, William J. and Robert B. Seidman. 1971. Law, Order, and Power. Boston, MA: Addison-Wesley. 
Closen, Michael L., Donald H.J. Hermann, Patricia J. Horne, Scott H. Isaacman, Robert M. Jarvis, Arthur S. Leonard, Rhonda R. Rivera, Mark Scherzer, Gene P. Schultz, Mark E. Wojcik. 1989. AIDS: Cases and Materials. Houston, TX: John Marshall.

1990. AIDS: Cases and Materials, 1990 Supplement. Houston, TX: John Marshall.

Conrad, Peter and Joseph Schneider. 1980. Deviance and Medicialization: From Badness to Sickness. St Louis, MO: C.V. Mosby.

Cowan, Thomas A. 1980. "Group Interests." Pp. 82-90 in The Sociology of Law, edited by W. M. Evan. New York, NY: The Free Press.

Dolgin, Janet L. 1985. "AIDS: Social Meanings and Legal Ramifications." Hofstra Law Review 14:193-209.

Duesberg, Peter H. 1991. "Human Immunodeficiency Virus and Acquired Immunodeficiency Syndrome: Correlation but Not Causation." Pp. 42-73 in The AIDS Reader: Social. Political, and Ethical Issues, edited by N. F. McKenzie. New York, NY: Meridian.

Durkheim, Emile. 1933. The Division of Labor in Society. (Trans. George Simpson). New York, NY: MacMillan.

Edgley, Charles and Dennis Brissett. 1990. "Health Nazis and The Cult of the Perfect Body: Some Polemical Observations." Symbolic Interaction 13:257-79.

Ehrlich, Eugen. [1936] 1962. Fundamental Principles of the Sociology of Law. Translated by Walter L. Moll. New York, NY: Russell \& Russell.

Epstein, Steven. 1988. "Moral Contagion and the Medicalizing of Gay Identity: AIDS in Historical Perspective." Law, Deviance and Social Control 9:3-36.

Erickson, Kai T. 1966. Wayward Puritans: A Study in the Sociology of Deviance. New York, NY: Wiley.

Friedmann, Wolfgang. 1964. Law in a Changing Society. Baltimore, MD: Penguin Books.

Gilbert, Arthur N. 1975. "Doctor, Patient, and Onanist Diseases in the Nineteenth Century." Journal of the History of Medicine July:217-34.

---- 1980/81. "Conceptions of Homosexuality and Sodomy in Western History." Journal of Homosexuality 6:Fall/Winter. 
Grmek, Mirko D. 1990. History of AIDS: Emergence and Origin of a Modern Pandemic. Trans. by R. C. Maulitz and J. Duffin. Princeton, NJ: Princeton University Press.

Hilts, Philip J. 1991. "AIDS Virus Off Immigration List." The Oregonian. January 4, morning ed.:C7.

Holmes, Oliver Wendell. 1968. "The Path of the Law." Pp. 19-28 in The Sociology of Law, edited by R. J. Simon. San Francisco, CA: Chandler.

Jones, Robert Alun. 1986. Emile Durkheim: An Introduction to Four Major Works. Beverly Hills, CA: SAGE.

Kass, Frederic C. 1987. "Schoolchildren with AIDS." AIDS and the Law: A Guide for the Public. Pp. 66-80, edited by H.L. Dalton, S. Burris and the Yale AIDS Law Project. New Haven, CT: Yale University Press.

Kelsen, Hans. 1967. Pure Theory of Law. Translated by Max Knight. Berkeley, CA: University of California Press.

Kerlinger, Fred N. 1986. Foundations of Behavioral Research. 3rd ed. Fort Worth, TX: Holt, Rinehart and Winston.

Kramer, Larry. 1991. "The Plague Years." Pp. 113-21 in The AIDS Reader: Social, Political, and Ethical Issues, edited by N. F. McKenzie. New York, NY: Meridian.

Leinwand, Donna. 1991. "CDC Finds Dentist Practices Poor Hygiene, Likely Infected Patients." The Oregonian. January 17, morning ed.:A19.

Leonard, Arthur S. 1987. "AIDS in the Workplace." Pp. 109-25 in AIDS and the Law: A Guide for the Public, edited by H. L. Dalton, S. Burris and the Yale AIDS Law Project. New Haven, CT: Yale University Press.

Luhmann, Niklas. 1985. A Sociological Theory of Law, translated by E. King and M. Albrow, edited by M. Albrow. Boston, MA: Routledge \& Kegan Paul.

Marcotte, Paul. 1990. "Record AIDS Verdict." ABA Journal. June:26.

McGuirl, Marlene and Robert N. Gee. Fall, 1985. "AIDS: An Overview of the British, Australian, and American Responses." Hofstra Law Review $14: 107-35$.

McKenzie, Nancy F. 1991. "Introduction: The Demands of the HIV Epidemic." Pp. 1-16 in The AIDS Reader: Social, Political, and Ethical Issues, edited by N.F. McKenzie. New York, NY: Meridian. 
McKinlay, John R. and Sonja M. McKinlay. 1981. "Medical Measures and the Decline of Mortality." Pp. 12-30 in The Sociology of Health and Illness, edited by P. Conrad and R. Kern. New York, NY: St. Martin's Press.

Mesce, Deborah. 1991. "U.S. to Admit Foreigners with HIV." The Oregonian. January 26, morning ed.:A13.

Nader, Laura. 1968. "The Anthropological Study of Law." Pp. 220-242 in The Sociology of Law, edited by R. J. Simon. San Francisco, CA: Chandler.

Nader, Laura and David Serber. 1980. "Power as Process in Regulation." Pp. 331-342 in The Sociology of Law, edited by W. M. Evan. New York, NY: The Free Press.

National Academy of Sciences. 1991. "HIV Infection and Its Epidemiology." Pp. 74-99 in The AIDS Reader: Social, Political, and Ethical Issues, edited by N. F. McKenzie. New York, NY: Meridian.

Newsweek. 1990. "New Dental Dilemma: A Visit with AIDS." October 15:80.

Ogilvie, Daniel M., Philip J. Stone and Edward F. Kelly. 1987. "ComputerAided Content Analysis." Program Evaluation Kit. Newbury Park, CA: SAGE Publications, Inc.

Oregon State Board of Health. 1969. "The Story of Mary Mallon." Oregon Health Bulletin. January, 47:1-4.

Perdew, Sue. 1990. Facts About AIDS: A Guide for Health Care Providers. Philadelphia, PA: J.B. Lippincott.

Phillips, Paul. 1980 Marx and Engels on Law and Laws. Totowa, NJ: Barnes \& Noble Books.

Pound, Roscoe. 1951. Justice According to Law. New Haven, CT: Yale University Press.

Quinney, Richard. 1970. The Social Reality of Crime. Boston, MA: Little, Brown and Company.

Rheinstein, Max. 1954. Max Weber on Law in Economy and Society, edited with introduction and annotations by Max Rheinstein, translation from Max Weber, Wirtschaft und Gesellschaft, Second Edition (1925) by E. Shils and M. Rheinstein. Cambridge, MA: Harvard University Press.

Rosenberg, Charles E. 1988. "Disease and Social Order in America: Perceptions and Expectations." Pp. 12-32 in AIDS: The Burdens of History, edited by E. Fee and D.M. Fox. Berkeley, CA: University of California Press. 
Sagarin, Edward and Robert J. Kelly. 1981. "Morality, Responsibility, and the Law: An Existential Account." Pp. 21-43 in Law \& Deviance, edited by H. Laurence Ross. Beverly Hills, CA: SAGE.

Schmalz, Jeffrey. 1988. "Family Afflicted by AIDS Finds Better Life." The New York Times. October 2:I,20:3.

Schur, Edwin M. 1968. Law and Society: A Sociological View. New York, NY: Random House.

Schwartz, Frederick A. O. and Frederick P. Schaffer. 1985. "AIDS in the Classroom." Hofstra Law Review 14:163-91.

Scott, Walter. 1991. "Personality Parade." The Oregonian. October 6:2.

Selznick, Philip. 1968. "The Sociology of Law." Pp. 190-200 in The Sociology of Law, edited by R. J. Simon. San Francisco, CA: Chandler.

1969. Law, Society, and Industrial Justice. New York, NY: Russell Sage Foundation.

--- 1979. "Sociology of Law." Pp. 50-59 in International Encyclopedia of the Social Sciences, edited by D. L. Sills. New York, NY: MacMillan.

Shilts, Randy. 1988. And the Band Played On: Politics. People and the AIDS Epidemic, 2nd ed. New York, NY: Viking Penguin.

Simon, Rita James. 1968. "Introduction to Part I -- Sociological Jurisprudence: Stage One." Pp. 3-8 in The Sociology of Law, edited by R. J. Simon. San Francisco, CA: Chandler.

Sloan, Irving J. 1988. AIDS Law: Implications for the Individual \& Society. New York, NY: Oceana Publications, Inc.

The Oregonian. 1990. "Family to Get $\$ 1.8$ Million." October 24, morning ed.:B10.

The Oregonian. 1991. "2nd Patient of AIDS Dentist Sues." February 15, morning ed.:A16

Webster's New Collegiate Dictionary. 1977. Springfield, MA: G.\&.C. Merriam Company.

Wiener, Carolyn L. 1981. The Politics of Alcoholism: Building an Arena Around a Social Problem. New Brunswick, NJ: Transaction Books.

Wikler, Daniel and Norma J. Wikler. 1991. "Turkey-baster Babies: The Demedicalization of Artificial Insemination." The Milbank Quarterly 69:5-40. 


\section{Court Cases}

Arline v. School Board of Nassau County, 692 F.Supp. 1286 (M.S. Fla. 1988)

Brown v. Board of Education of Topeka, 347 U.S. 483 (1954)

Chalk v. U.S. District Court for the Central District of California, 840 F.2d 701 (9th Cir. 1988)

District 27 Community School Board v. Board of Education of the City of New York, 130 Misc. 2d 398, 502 N.Y.S.2d 325 (Sup. Ct. 1986)

New York State Association of Retarded Children v. Carey, 612 F.2d 644 (2nd Cir. 1979)

Plessy v. Ferguson, 163 U.S. 537 (1896)

Plyler v. Doe,

457 U.S. 202 (1982)

School Board of Nassau County v. Arline, 107 S.Ct. 1123 (1987)

United States v. Medical Society of South Carolina, 298 F.Supp 145 (D.S.C. 1969)

White v. Western School Corp,

No. IP-85-1192-C (S.D. Ind. Aug. 16, 1985) 


\section{APPENDIX A}

DICTONARY OF IDENTIFIERS FOR BUSINESS/EMPLOYMENT, ACCESS TO EDUCATION, AND MEDICAL CARE DELIVERY 


\title{
Business/Employment
}

\author{
AIDS as a handicap \\ discrimination based on AIDS status \\ dismissal based on AIDS \\ dismissed \\ employee \\ employee refuses to interact with individual with AIDS \\ employer \\ guidelines on AIDS in workplace \\ illegal dismissal \\ refusing jobs to individuals with AIDS \\ removed because they are gay \\ violation of state and federal disability laws \\ work
}

\section{Access to Education}

allowed in classroom

attend city public schools

attend regular school classes

barred from returning to school

Board of Education

boycott by parents protesting attendance of child with AIDS

children exposed to AIDS not allowed into classroom

children with AIDS should be allowed to attend

danger of spreading AIDS in classroom setting

discrimination

District 27

Education Department policy on children with AIDS

hemophiliac children

home tutoring

New Jersey Education Department

non-automatic exclusion from school based on AIDS status

Orange County, Florida

Philadelphia Board of Education

policy on school-age children with AIDS

protect pupils' privacy

public school

public threat to other pupils

Queens school districts

Ray family, Ray brothers

separate AIDS children from non-AIDS children

special instruction

students and teachers with AIDS

university

White, Ryan

will determine if child will attend school 


\section{Medical Care}

Acer, David DMD

American Red Cross

Axelrod, David MD (New York State Health Commissioner)

Bergalis, Kimberly

blood bank

blood center(s)

blood disease

blood donation(s)

blood donors

bloor drive

blood product(s)

blood supply(ies)

blood test confidentiality/discrimination

blood transfusion(s)

body fluids

contaminated blood

doctors and dentists

emergency room

giving blood

gowns, gloves or other protection

health care trainig

health care workers

health care worker/patient contact

health officials

hospital treatment, home health care, or hospice center

hospitalization

hospitals

inadequate sterilization

invasive procedures and surgery

Kaposi's sarcoma

medical and dental associations

nursing home

organ and tissue transplant

patients

physician or surgeon

plasma product

providing adequate health care

special restrictions placed on health care providers

state health department

surgery

transplant surgery

virus HTLV 


\section{APPENDIX B}

COMPLETE LISTING OF COURTS CONTAINED IN GENERAL FEDERAL LIBRARY OF LEXIS/NEXIS COURTS FILE 


\section{General Legal Libraries}

\section{GENFED}

General Federal Library

This library allows you to use custom file selection to combine court files.

$$
\text { fat }
$$$$
\text { US Uniled States Supreme Court decisions Irom }
$$
1790

USAPP Courts or Appeals from 1789

Court of Appeals for the Federal Circuit from October 1982

-Temporary Emergency Coun o Appeals from 1972

-Former US. Emergency Coun d Appeals Irom 1942 to 1962

CAFC Court o Appeals for the Federal Circuin from October 1982

DIST -District Courts Irom 1789

Court of International Trade from Novernber 1980 Judicial Panel on Mulfidistricl Litigation Irom 1968

-Special Court. Raa Reorganization Act from 1974

CIT Court of Intermational Trade irom November 1980

CLCT Clains Coun from October 1982

Court of Clains Irom 1863 lo September 1982

IC US. Tax Court opinions from 1942

BANKR U.S. Bankruplcy Courts from October 1979

CUSTCT US. Customs Coun from June 1962 to October 1980

CVA Court of Velerans Appeals opinions from December 1989

coURTS -Combined US, USAPP. CAFC. DIST. CIT. CLCT, TC, BANKR, CUSTCT, and CVA fles, Commerce Court irom 1911 to 1913, Court o Customs and Patent Appeals from January 1952 to Seplember 1982, US. Tax Coun Memorandum decisions from 1942. Board of tax Appeals decisions from 1924 lo 1942. and ALA annotalions

COURT2 Combined US. USAPP. CAFC. DIST, CIT. CLCT, RC, BANKR, CUSTCT, and CVA files, Commerce Courn Irom 1911 to 1913. Coun o Customs and Patent Appeals lrom January 1952 to September 1982, US. Tax Court Memorandum decisions from 1942. Board o Tax Appeals decisions from 1924 to 1942. excludes ALP annolations

SUPCIR -Combined US, USAPP and CAFC lites

CUARNT Combined US, USAPP, CAFC, OIST. CIT. CLCT. TC. BANKR, CVA files from January 1989, exchides ALR annolations

NEWER Combined:

United Stales Supreme Court decisions Irom Jarwary 1945

Couns of Appeals from January 1945

Cour of Customs and Patent Appeals from

January 1952 to Seplember 1982

District Courts trom January 1945

Court of International Trade from November 1980

Cour or Velerans Appeals from December 1989

Court of Claims from January 1945 lo

Seplember 1982

Claims Courl from Oclober 1982

Customs Court from June 1962 to October

1980

-Bankruptcy Courts from October 1979

US. Tax Coun opinions from 1945

US. Tax Coun Memorandum decisions from 1945

OLDER Combined

Uniled States Supreme Court decisions Irom 1790 to December 1944

-Courls of Appeals from 1789 lo December 1944

District Counts from 1789 to December 1944

-Circuil Courts from 1789 to 1911

Commerce Court from 1911 to 1913

Court of Claims Irom 1863 to December 1944

U.S. Tax Court opinions from 1942 10

December 1944

US. Tax Coun Mernorandum decisions Irom

1942 10 December 1944

-Board ol Tax Appeals decisions from 1924 to 1942

1ST

2ND

$3 R D$

$4 \mathrm{TH}$

5TH

6TH

$7 \mathrm{TH}$

BTH

9TH

107

$11 \mathrm{TH}$

CADC

FED

ICIR

2CIR

3CIR

4CIR

SCIR

6CIR

$7 \mathrm{CIR}$

8CIR

9CIR

10CIR

11CIR

DCCIR

1DIST

2DIST

3D!ST

4DIST

SOIST

6DIST

7DIST

8DIST

9DIST

1ODIST

110IST

DCDIST
USAPP and DIST cases from First Circuil

Irom January 1912

USAPP and DIST cases from Second Circuil

Irom January 1912

USAPP and DIST cases Irom Third Circuit

from January 1912

USAPP and DIST cases Irom Fourth Circuit

from January 1912

USAPP and DIST cases Irom Fitth Circuit

Irom January 1912

USAPP and DIST cases Irom Sixth Circuit

Irom January 1912

USAPP and DIST cases from Seventh Circuil

from January 1912

-USAPP and DIST cases Irom Eighth Circuit

from January 1912

-USAPP and DIST cases from Ninth Circuit

from January 1912

USAPP and DIST cases from Tenth Circuit

and former Eighth Circuit Irom January 1912

-USAPP and DIST cases from Eleventh Circuit

and former Fith Circuit from January 1912

-USAPP and DAST cases from District of

Columbia Ciranit from January 1912

Combined Federal Circuit, Courl ol Customs

and Patent Appeals. CT, CLCT, CUSTCT and CVA niles

USAPP cases from First Circuit from January 1912

USAPP cases trom Second Circuit from

January 1912

-USAPP cases from Third Circurt from

January 1912

-USAPP cases Irom Fourth Circuit from

January 1912

-USAPP cases from Fith Circunt from January 1912

-USAPP cases from Sixth Circuit Irom

January 1912

-USAPP cases from Seventh Circuit from January 1912

-USAPP cases Irom Eighth Circuit from

January 1912

-USAPP cases from Ninth Circuit from

January 1912

-USAPP cases from Tenth Circuil and lormer Eighth Circuit Irom January 1912

-USAPP cases from Eleventh Circult from

October 1981 and former Fith Circuil cases

USAPP cases Irom District a Columbia

Circult from May 1919

-DiST cases from First Circuit from January

1912

-DIST cases trom Second Circuit from

January 1912

-DIST cases from Third Circuit from January 1912

-DIST cases from Fourth Circuil from January 1912

DIST cases Irom Fith Circuil from Jamuary

1912

DIST cases from Sixth Circuil from January 1912

DIST cases from Seventh Circuit Irom

January 1912

DIST cases from Eighth Circuit Irom January 1912

-DIST cases from Ninth Circuit Irom January 1912

DIST cases from Tenth Circuit and former

Eighth Circuit from January 1912

DIST cases Irom Eleventh Circuit and forme Fith Circuit from January 1912

-DIST cases from District of Columbia Circuit Irom January 1912 
RICO

All topic Racketeer Influenced \& Lornupt Organizations ACI

Civit and criminal case law combined: Hnited:States?Peports fromvanuary 1970

United States Courls of Appeals from January 1970

United States District Couns from Oclober 1979

Also contains:

Federal case law from 1934 with respect to the Anti-Rackeleering Acl ol 1934 and the Hobbs Act of 1945, as amended CFR Tilles 12.17 and 28 Applicable Federal Register trom $\$$ bly 1980

CLSDFN FRCP 23, as amended, class action case law induding common question of law or lact. adequate representation. discovery. binding elfect, forum certification, opl out, subclasses allorney lees. standing. amount in controversy. dismissal, compromise subject matters:

-US. Aeports from September 1938

-U.S. Courts of Appeal Irom Seplember 1938

-US. District Courts from Seplember 1938

-Barknupicy Courts from October 1979 phus FRCP 23.1, as amended, derivalive action case law from January 1938 , inctuding demand, jinder of corporation, standing. ofversity, venue adequale representation. notice security for expenses, attorney lees subject matters:

-FACP 42, as amended, case law Muttidistric Docket and Litigation case law -28 USC 1407, 2112 case law, and. applicable dass action and denivative action old equity niles case law

RECORD* Combined 1015T. 100TH and 99TH files

10151* Congressional Record trom the 1015t Congress from January 1989

100TH* Congressional Record Irom the 100th Congress Irom January 1987 to Novenber 1988

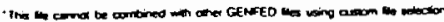

991H* - Congressional Record from the 99th Congress irom January 1985 bo Novernber 1986

SENATE* -Senale debales and proceedings irom 101st 100th and 99th Congresses from January 1985

HOUSE" House debales and proceedings from 101st 100th and 99th Congresses frorri January 1985

REMARK" Extensions d Remarks Irom the 1014, 100th and 99th Congresses Irom January 1985

DIGEST* Daily Digest from the 10ist. 100th and 9gth Congresses from January 1985

101SEN* -101s Congress Senate debales and proceedings Irom January 1989

101HSE*-101s Congress House debates and proceedings trom January 1989

101RMK - 101st Congress Extension of Rernarks Irom January 1989

1010IG* -1015t Congress Daily Digest from January 1989

BILLS. Full text of bills introduced in the House and Senate

- Tracking of congressional bills from introduction to resolution - Billcast'" Legislative Forecasts from 1015 Congress and status of legistation from lormer Congresses

BKRLH* Combined bankruptcy acts, bills, reports and public laws including -Bankruplcy Relorm Act of 1978 -Banknuplcy Tax Act of 1980

-Banksuptcy Amendments and Federat Judgeship Act of 1984

-Bankruplcy Judges. U.S. Trustees, and Family Farmer Bankruptcy Act of 1986 -Retiree Benefits Bankruptcy Prolection ACt of 1987

-Miscellaneous bankfuptcy legislative histories: House Reporl 2807. Senate Repon No. 96.230: House Report 4935, House o Representatives Report No. 97.420
ENVI H* - Combined emironmental legistalive histories" including:

Clean Air Ac Amendments of 1977

Comprehensive Erwirormental Response.

Compensation, and Liability Adt of 1980

-National Emirormental Policy Act of 1969

-Supertund Amendments and Reaulhorization

Ad of 1986

TAXLH• Tax legislative histories induding:

-Public Laws - legislative sessions 83-2

through 100.1. 1954 to present

House Ways and Means Committee. Senate

Finance Committee House and Senate

Corderence Cormmittee bills and reports from 1954

Joint Commitee Prints Irom 1981 (selected)

-Joint Cormmittee Blue Books from 1976

Proposed lax and pension legislation

USCS

-United Stales Code Service

USCNST* -United States Constitution

PUBLAW* -United States Public Laws starting with 100 hh Congress, 2nd Session

USCOOE' Combined USCS. USCNST and PUBLAW fites (Irom the 10ist Congress)

FEDREG* -Federal Register trom Juty 1980

$\mathrm{CFA}^{*} \quad$ Code of Federal Regulations

CFR88* -1988 Code of Federal Regulations

CFR87 $7^{\circ} \quad 1989$ Code of Federal Regulations

CFR86" $\quad .1986$ Code of Federal Regulations

CFRB5* -1985 Code of Federal Regulations

CFRB4* -1984 Code of Federal Regulations

CFR83* -1983 Code of Federal Regulations

CFR82" $\quad-1982$ Code of Federal Regulations

CFRB1" .1981 Code of Federal Regulations

ALLCFR* Combined CFR88, CFR87, CFR86. CFRB5 CFR84 CFR83 GFA2Land:CFR81 thes

ALLREG* Combined CFR and FEDREG fies

FRAP: Federal Rules of Appellate Procedure as amended to July 1986

BKRULE* .Federal Rules of Bankruptcy Procedure 1987 Amendments and 1983 Rules

FRCP* -Federal Rules or Civil Procedure as amended to November 1988

FRCAP. Federal Rules $\alpha$ Criminal Procedure as amended to Novenber 1989

FRE* Federal Rules of Evidence as amended 10 Oclober 1987

SUPRUL: US. Supreme Court Rules, eflective January 1990

VACRUL* US. Claims Court Vaccine Rules, elfeclive January 1989

CLRUL Rules of the U.S. Clairns Court. as amended to November 1985

TAXRUL: -Rules of Procedure of the US. Tax Count. as amended to January 198

VEIRUL" Court of Veterans Appeals Inlerim Rules. effective December 1989

AOMRUL* -Supplemental Rules for Admiralty and Martitine Claims, as amended to Aurgus 1987

RULES - Combined FRAP. BKRULE. FRCP. FRCRP, FRE, SUPRUL, VACRUL, CLRUL. TAXRUL VETRUL and AOMRUL liles

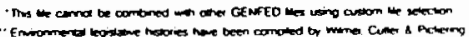

GLINE* Federal Sentencing Guidelines

FSENR* Federal Sentencing Reporter from 1988

DOSBUL* -Department of State Bulletin from January 1984

FJA* Federal Judiciary Almanac, tates edition. 1987

COMGEN*-Comptroter general decisions from July 1921 (Unreported decisions trom January 1981)

USAG. -Opinions of the Uniled Slates attorney general from 1791 Opinions of the Otice $\alpha$ Legal Counset from 1977 to 1982

BRIEFS* Filings for all Suprerne Court cases orally argued, beginning with the October 1979 lerm

CONDEC* Emironmental Prolection Agency Consent Decrees

PRESOC* Presidential documents from January 1981

ALLFAR* Entire Federal Acquisition Regulations and Supplements. 48 CFR Pans 1 et seq. Irom Aprit 1984

USLWD United States Law Week Daily Eodition from June 1987, updated 3:30 p.m. EST/EDT 
USLW - United States Law Week from July 1982

BNAWI* - BNA Washington Insider from September 1987

CNGVO*' Committee profiles, schedules and voles, mernber legislative records and voting records of Congress

CNGFIN* -Member financials and honorania, political action committees and congressional honoraria reports

CNGMEM* Congressional member profiles, district and stale profiles and areas of dominant influence

CNGRES - Combined CNGVT, CNGFIN and CNGMEM fles

AIDS* AIDS Policy and Law from January 1986

AMLAWR" - The American Lamer from January 1987

ASBSTS* -Asbestos Abatement Report from June 1987

BUSLAW* The Business Lamyer Irom Nowember 1981

EXPTLW* The Expert and the Law from Decernber 1981

INTLAW* -The International Lamyer from Winter 1981

LGECON" -Law Practice Management from January 1990 ABA Legal Economics from January 1982 to Decernber 1989

LGLTME* -Legal Times from Jamuary 1982

MNLAWR* Manthattan Lawyer from September 1987

NTLNL* - National Journal Irom Jamuary 1977

NTLAWJ* -The National Law Journal from April 1982

NYUAWs: The New York Law Journal Irom September 1989

PUBS* Combined AMLAWR, BUSLAW, EXPTLW, INTLAW, LGECON, LGLTME, MNLAWR, NTLNNL, NTLAWJ and NYLAWJ files

ALL* Accounting and audit literature including standards and principles of the accounting prolession, current and superseded

GUIDE* -Descriptions of files available in the GENFED library

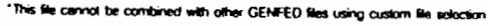




\section{APPENDIX C}

COMPLETE LISTING OF COURTS CONTAINED IN STATES LIBRARY OF LEXIS/NEXIS COURTS FILE 
STATES

States Library

This litsary allows you to use custom file selection.

ALA Alabarna Supreme Court from January 1965

Alabarna Court ol Criminal Appeals from

Oclober 1969

Alabarna Court $d$ Cinl Appeals from

Navember 1969

Alabarna Coun od Appeals from January

1965 to September 1969

ALTAX Alabarna Department of Reverue admiristrative opinions, rules and regulations Irom Decernber 1983

ALAG Alabarna attorney general opinions from January 1974

ALCODE* Mictie's Code ol Alabarna (Al titles, constitution and ALS

ALAS Alaska Supreme Court trom January 1965 Alaska Coun of Appeals Irom Novernber 1980

AKTAX Alaska Department of Revenue decisions Irom January 1980

AKAG Alaska attomey general opinions from January 1977

AKCOOE* -Michie's Alaska Statules (AIl tites, constitution and ALS)

ARIZ Arizona Supreme Court from February 1898 Arizona Cout of Appeals from January 1965

AZTAX Avizona Board of Tax Appeals irom Decernber 1982

AZSEC Arizona Corporations Commission orders from February 1982

AZAG. Arizona attorney general opinions from Seplember 1975

AZCODE* Arizona Revised Staiutes (All tites constitution and ALS

ARK Arkansas Supreme Court from Jaruary 1965 Arkansas Court ol Appeals from August 1979

ARAG Arkansas attorney general opinions from January 1977

ARCODE- Michie's Arkansas Code Annolated (All tilles. constitution and ALS)

CAL California Supreme Court Irom 1883 Cafilornia Courts ol Appeals from January 1944

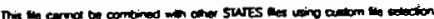

CATAX Calilomia Board of Equalization opinions orders rules and regulations, guides and bulletins from Jaruary 1930

Calikorna: Franchise- Tax Baard legal nuings and notices from December 1953

CASEC Calidornia Departmen of Corporations decisions from Jaruary 1969

CAENV Calikornia Water Resources Control Board decisions from 1924

CAPUC Calitornia Public Litities Commission decisions from 1969

CAAG Calilornia attorney general opinions from January 1977

CACOOE' Deering's California Codes (All codes constitution, court rules and ALS)

CAINC- California Secrelary of State corporation information taken Irom corporale filings

CALTP* California Secretary of State limited partnership information

CASOS* Combined CAINC and CALTP files

COLO Colorado Supreme Court Irom 1864 Colorado Court ol Appeals from January 1970

COTAX Colorado Department or Revenue rules. regulations. bulletins and determinations from September 1981

COAG Colorado attoney general opinions Irom January 1975

COCODE ${ }^{-}$-Colorado Revised Slatutes (All tilles. constitution and ALST

COSOS* Colorado Department of State corporation and limited partnership intormation

COTM - Colorado Department ol Slate trademark and service mark information
CONN - Connecticut Supreme Court from 1938 -Connecticut Appellate Court Irom Novernber 1983

Connecticut Superior Coun \& Coun od

Cominon Pleas from January 1961

Connecticut Circuit Court Irom January 1961 to May 1974

CIPUC -Connecticur Department o Public Utility Control Irom January 1980

CTAG - Connecticut attorney general opinions from January 1977

CTCODE* -General Statules of Connectiant (All tilles and constitution)

- Connecticut Public and Special Acts

CTINC" Connecticur Secrelary of State corporation intormation

DEL -Delaware Supreme Court from January 1945 Delaware Count of Chancery Irom January 1945 -Delaware Superior Cout from Jaruary 1945

DETAX -Delaware Department of Finance lax rutings. techrical information memorandums, notices regulations and tax guides from Apri 1979

DEPUC Delaware Public Service Corrmission from January 1981

DECODE* -Mictie's Delaware Code Annotaled (All titles, constitution and ALS]

DESOS* Delaware Secretary of State corporation information

DC -District of Columbia Appeals Court Irom January 1943

FLA Forida Supreme Court Irom 1886 -Forida District Courts of Appeals from Juty 1957

FUAX Florda:Department :or :Revenue :-dectaratory statements:and linal 'orders from May' 1979 Florida Technical Assistance Advisements and Jemporary Fecturical Assistarce Advisernenls from Novernber 1981 -Floxida Departmend d $d$ - Administration hearings and final orders from February 1979

FLSEC Florida Securities Cormmission from January 1973

FLENV Florida Environmenlal and Land Use decisions trom January 1979

FUPUC Florida Public Service Commission from January 1970

FLAG Florida attorney general opinions from January 1977

FLCOOE* -Fonida Statules (AH lites and constitution) -Florida General Laws

FLADMN" Florida Administrative Code

GA Georgia Supreme Court from Jamuary 1937 -Georgia Courl of Appeals from January 1945

GATAX Georgia Secretary or State rules and regulations

GASEC Georgia Commissioner of Securities from 1973

GAENV Georgia Board of Natural Resources decisions and orders Irom 1975

GAAG Georgia ationey general opinions from January 1976

GACOOE- Olficial Code of Georgia Annolated (All titles. constitution and ALS)

GAINC* Georgia Secretary d Stale corporation informalion taken from corporate filings

GALTP* Georgia Secretary of State limited partnership indormation

GASOS* Combined GAINC and GALIP files

HAW Hawaï Supreme Court Irom January 1965 Hawaii intermediate Court of Appeals from May 1980

HIAG Hawaii attorney general opinions from January 1977 
HICODE* -Michie's Hawail Revised Stalutes Annotated and Constitution (All tilles, constitution and ALS)

IDA Idaho Supreme Court Irom Jaruary 1944 -Idatro Court of Appeals from January 1982

IDAG tdaho attorney general opinions from January 1977

IDCODE: -Michie's Idaho Code (All litles, consitution and ALS)

ILL -Illinois Supreme Court from 1885

- Illinois Appellate Court from January 1944

ILTAX -llinois tax regulations effective from May 1962

-llinois Department of Revenue privale letter rulings from January 1981

ILSEC -llinois Secretary of State, Securities Departmenl and Department of Licensing Business. Securities Division from 1980

ILENV -llinois Pollution Control Baard decisions from September 1970

\#UPUC -llinois Commerce Commission opinions from January 1973

ILAG -flinois ationey general opinions from January 1977

ILCOOE* -illinois Revised Statutes and Constlution (All general and permanerd laws, coun rudes and ALST

UUNC* -Hinois Secretary or State corporation inlormation taken from corporale fitings

IND Indiana Supreme Court from January 1934 -Indiana Court of Appeals from January 1944

INTAX Indiana Tax Court from July 1986 Indiana Department of Reverue rulings and bulletins from Jaruary 1978

INPUC Indiana Utility Regulatory Cormmission from Aprit 1975

INAG Indiana attorney general opinions from February 1977

INCODE* -Michie's Burns Indiana Stalutes Annotaled (All litles, constitution and ALS)

INSOS* Indiana Secretary d State corporation and himiled partnership infomation

IOWA lowa Supreme Court from January 1960 towa Appeals Court Irom Seplember 1977

IATAX -kwa District Coun rulings and findings Irom June 1951

-lowa State Board of Tax Review orders, lindings and clarilications Irom July 1968 - lowa Department of Revenue and Finance (previously Department of Revenue. previously State Tax Commission) orders proposed orders, findings nulings statements, bricts and petitions from Seplember 1957

IASEC Iowa Insurance Department, Securities Division, administrative decisions and no-action letters from February 1968

IAAG lowa attorney general opinions from January 1977

IACOOE* Code of lowa (All lites and constitution) lowa Adopled Bills

KAN Kansas Suprerne Coun Irom January 1963 -Kansas Court ol Appeals Irorn January 1977

KSTAX Kansas Board ol Tax Appeals orders and denials Irom March 1982 Kansas Director of Taxalion orders from March 1976

KSSEC Kansas Securities orders, decisions, releases, no-action letters and inter-agency memoranda from January 1934

KSAG Kansas allorney general opinions from January 1977

KSCOOE* -Kansas Statules Annotaled (All lilles. constilution. Supreme Court rules and ALS)

KSADMN* Kansas Administrative Regulations

KY Kentucky Suprerne Courl from December 1954 -Kentucky Court ol Appeals from January 1976

KYIAX Kentucky Board of Tax Appeals from January 1979

KYSEC Kentucky Department of Financial Institutions, Oivision of Securities, administrative decisions and noaction letlers from March 1975

KYAG Kentucky attorney general opinions from January 1977
KMCODE" -Banks-Baldwiris Kentucky Revised Statules Annotated (All titles, court rules and constitution) -Baldwinis Kentucky Revised Statutes and Rules Service

KYSTAT* -Michie's Kentucky Revised Statules Annolated (All tilles and constitution) Kentucky Acts

LA Louisiana Supreme Courl Irom January 1887 touisiana Courts of Appeals Irom January 1944

LATAX Louisiana Board of Tax Appeals judgments. motions and consent orders from June 1979

LAENV Louisiana Departmenl of Emironmental Quality materials from 1904

LAPUC Louisiana Public Service Commission decisions from March 1972

LAAG Louisiana attorney general opinions from Seplember 1974

LACODE* -Losisiana Slatules (All litles, conslitution and ALS)

ME -Maine Supreme Count Irom January 1965

MEAG -Maine attorney general opinions from January 1984

MECODE- Maine Revised Statules (All titles. constitution and ALST

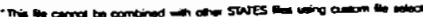

MD -Maryland Court ol Appeals Irom January 1937 - Maryland Court a Special Appeals from February 1967

MDTAX Maryland Tax Court recorrmendations \& orders lrom January 1979

MDSEC - Maryland Securities orders, releases and letters from Seplember 1967

MDPuC -Maryland Public Service Commission from August 1976

MDAG -Maryland atorney general opinions Irom January 1977

MDCOOE*-Michie's Annolated Code of Maryland (All codes articles, constitution and ALS)

MDINC" -Maryland Stale Department ol Assessmerts and Taxation corporalion irformation taken Irom corporate flings

MDUP* Maryland State Departmend of Assessments and Taxation frniled parnership information

MDPEND* -Maryland Stale Department of Assessments and Taxation pending document intormation

MDSOAT* Combined MDINC, MDLTP and MDPENO rdes

MASS Massachusetts Supreme Judicial Court from 1899

Massachusetts Appeals Court from Decernber 1972

MATAX -Massactusetts Appellate Tax Board decisions Irom February 1979

Massachusetts Department $\alpha$ Revenue:

-Tectinical inlomation releases from Manch 1987

- Letter rulings from February 1977

MASEC Massachusetts Securities orders, decisions, releaces no-action letters and inter-agency mernoranda from Jaruary 1967

MAAG Massachusetts attorney general opinions Irom January 1977

MAINC- Massachusetts Secretary of State corporation intormation taken from corporate flings

MALTP" -Massachusetts Secretary of Slate limited partnership inlormation

MASOS* - Combined MAINC and MALTP files

$\mathrm{MICH}$-Michigan Supreme Court from 1899 -Michigan Court of Appeals from Jarwary 1965

MIIAX -Michigan Tax Tribunal stalements, findings. opinions. judgments and orders trom January 1979 -Michigan Department of Treasury revenue administrative bulletins and private lelter fulings from August 1965

MIWORK -Michigan Workers' Compensation Appeal Board decisions from December 1983

MISEC -Michigan Department of Commerce Corporations and Securities Bureau decisions from January 1979 
MIPUC Michigan Public Service Commission opirions from Auqust 1973

MIAG Michigan attorney general upinions trom January 1977

MiCODE* -Michigan Compiled Laws (All laws and constitution)

MliNC* -Michigan Department d Commerce Corporation \& Securities Division, corporation information taken from corporate fifings
MILTP- Michigan Deparlment of Commerce,
Corporation \& Securilies Division, timited
MILTP. -Michigan Depariment of Commerce,
Corporation \& Securities Division, limited partnership information

MIPEND* - Michigan Department ol Commerce
Corporation \& Securities Division, pending document intormation

MICOMM' Combined MIING, MILTP and MIPENO fies

MINN Minnesota Supreme Coun from 1898 -Minnesola Appeals Court Irom Decernber 1983

MNTAX -Minnesola tax Courl decisions from Novernber 1979

MNPUC -Minnesola Public Utilities Commission opinions from Apri 1974

MNAG -Minnesola altomey general opinions from January 1977

MNCODE'-Minresola Stalules (Al parts and consitution) -Minnesola Stip Laws

MNADMN*-Minnesola Rules (Administrative Code)

MISS Mississippi Supreme Count from January 1965

MSAG Mississippi altomey general opinions from May 1951

MO Missouri Supreme Coun Irom January 1945 -Missouri Court of Appeals from January 1944

MOIAX -Missouri Tax Commission decisions from August 1980

-Missouri Administralive Hearing Commission Irom February 1980

MOSEC -Missouri Secuntities Corninission decisions from March 1971

MOPUC Missouri Public Service Commission Irom March 1972

MOAG -Missouri altorney general opinions from January 1977

MOCODE'-Revised Statutes of Missouri (All titles constitution, Supreme Court nules and ALS)

MOINC* -Missouri Secretary d State corporation information taken Irom corporate flings

MONT Montana Suprene Court from January 1965

MTTAX -Montana tax Appeals Board Irom August 1985

MTAG -Montana atiorney general opinions Irom February 1977

MTCOOE' -Montana Code Annolated (Ali tilles. court nuses and constitution)

NEB Nebraska Supreme Courl Irom January 1965

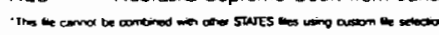

NECODE*-Revised Slatules of Nebraska (All litles and constitution)

Nebraska Stip Laws

NEV Nevada Supreme Court from Jamuary 1965

NVAG Nevada attorney general opinions from January 1977

NVCODE* -Michie's Nevada Revised Stalules Amotaled (All lities constitution and ALS)

NVINC. -Nevada Secretary of Slate corporation information taken Irorn corporate filings

NVLTP. Nevada Secretary of State limited partnership inlormation

NVSOS - Combined NVINC and NVLTP lies

NH New Hampshire Supreme Courn from January 1965

NHTAX New Hampshire Board of Tax and Land Appeals from October 1980

NHAG -New Hampshire attorney general opinions from January 1977

NHCOOE* New Hampstite Revised Statules Annotaled (All titles constilution and ALS

NJ -New Jersey Supreme Count from 1899 (belore 1948, the New Jersey Courl of Errors and Appeals)

-New Jersey Superior Court fram 1899 (belore 1949. the New Jersey Supreme Court)

NJIax New Jersey Tax Coun from Novernber 1979

NJENV New Jersey Department d Emirommental Protection decisions from 1980

N.JAG -New Jersey attorney general opirions from January 1977
NJCODE* -New Jersey Statutes (All titles, constitution and ALST

NM New Mexico Suprerre Court Irorn Jaruary 1965 New Mexico Courl of Appeals trom

Nanmber 1966

NMAG New Mexico atorney general opirions from January 1977

NMCOOE* Michie's New Mexico Statules Annotated (All tites constitution and ALS

NY .New York Court of Appeals from 1884 -New York Appellale Division from January 1912 New York Miscellaneous lower courts from January 1912

NYTAX: New York State Tax Cornmission hearing deteminations, advisory opirions. memoranda and adopled regulations from March 1978

New York Departmert $\alpha$ tax and Finance hearing delerminations, advisory coinions, memoranda and adopted regulations lrom March 1978

New York Division of tax Appeals deteminuations Irom March 1983 -New York tax Appeals Tribunal decisions and regutations from tuive 1983

NYCTAX New York City Department of Finano promulgaled regulations, letter rufings. hearing decisions statement of audn procedures tax policy buttetins and bookets from Aprit 1977

NYEN New York Departmend of Envirormental Conservation decisions from $\mathbf{1 9 7 0}$

NrCOMP New York Comptroller's opinions Irom January 1979

NYPUC New York Public Service Commission decisions froni January 1984

NYAG -New York attorney general opinions from February 1976

NYCOOE* New York Consolidated Laws Senvice-Ontine Edition (All codes, constitution and ALS)

NYLAWJ .The New York Law Journal Irom Seprember 1989

NC North Cardina Supreme Coun from January 1965

-North Carcina Court of Appeals trom February 1968

NCAG -North Carolina attorney general opinions Irom January 1977

NCCODE* -Mictie's General Statutes ol North Cardina (All tiltes constitution and ALS)

NO North Dakota Supreme Court from Januan 1965

North Dakola Court of Appeals trom Novernber 1987

NDAG North Dakota altorney general opinions from January 1977

OHIO Ohio Supreme Count from 1821 Otrio Courts of Appeals trom 1913 -Ohio Miscellaneous Courts from 1922

OHTAX Ohio Board ol tax Appeals from January 1977

OHENV -Ohio Enviomental Board ol Review decisions from Apra 1973

OHPUC Onio Public Utitities Commission opinions irom October 1973

OHAG Ohio attorney general opinions Irom January 1977

OHCODE'-Baldwiris Ohio Revised Code Anndaled (All titles. count rules and conslituion) - Baldwinis Ohio Legisalive Service

OHADMN $N^{*}$. Ohio Administrative Code (Banks.Balowin)

OKLA Oklahoma Supreme Cour fiom January 1965

.Oklahoma Court ol Criminal Appeals Irom January 1965

Oklahoma Coun of Appeats from May 1969

OKTAX Oklahoma tax Commission orders from August 1979

OKSEC Oklahoma Securities Commission Irom September 1969 
OKAG Oklahoma atlorney general opinions from January 1977

OKCOOE* -Oklahoma Statutes (All titles, constitution and ALST

ORE Oregon Supreme Court from Jamuary 1965 -Oregon Coun a Appeals from August 1969

ORTAX -Oregon Tax Court Irom January 1962

ORSEC Oregon Department a Commerce Corporation Division. administrative decisions and no-action letters from January 1981

ORAG Oregon attorney general opirions from July 1976

ORCODE* -Oregon Revised Statutes (A) titles constitution and ALS

PA Pennsytvania Suprerne Court from 188 Pernsylvania Superior Court from danuary 1944 - Pennsytvaria Commonweath Count Irom Odober 1970 -Philadelphia County Reporter from January 1978

PATAX Pemsytvania Board ol Finance and Revenue pelitions lor review and summaries from January 1971

PASEC Pennsytvania Securities Conrrission opinions Irom tune 1974

PAENV Pennsytvania Environmental Hearing Board Irom March 1972

PAPUC Penrsyivania Public Untuties Cormission Irom November $19 \% 0$

PAAG Pennsytvaria attomey general opinions from Febnary 1977

PACOOE- Pennsytvania Statules (All lites, constitution and ALS

PAADMN* Permsytvania Code (Adrninistrafive Regulations)

PASOS" Pennsylvaria Department od State corporation and knided parnership irlontmation

PATM* Pennsytuaria Department $\alpha$ State trademark and service mark inlormation

Fi fthode isand Supreme Cout Irom tanuary 1965

AICODE* Michie's General Laws of Rhode istand (AII lites constitution and ALS

SC South Carotina Supreme Court Irom January 1965

South Carolina Court of Appeaks from Odober 1983

SCTAX South Cardina Tax Commission decisions regulations private letter rufings, revenve nuings technical advice mernoranda. reverue procedures and itformation letlers from May 1960

SCAG South Carolina attorney general opinions irom January 1959

SD South Dakoka Suprerne Court from January 1965

SDAG South Dakola aliomey general opinions Irom January 1977

SDCODE* , Michieis South Dakola Codified Laws (AM tithes constitution and ALST

TENN Tennessee Supreme Court from January 1965 - Tennessee Court ol Criminal Appeals from Novernber 1967

- Tennessee Coun al Appeals tron January 1965

INTAX -Tennessee Depariment of Revenue and Ternessee Stale Board of Equalization Irom 1974

INAG -Tennessee anorney general opinions from January 1977

INCOOE* -Michie's Tennessee Code Annotated (All tilles. constitution and ALS

TEX Texas Supreme Court from 1886 Texas Court ol Criminal Appeals from January 1944 Teas Court d Appeals from Seplember 198 Texas Court or Civil Appeals from January 1944 to October 1981

IXTAX Texas comptroller decisions from July 1967

DXSEC Texas State Securities from 1957

TXPUC Texas Public Uitity Commission from Apid 1976

TXaG Texas attorney general opinions Irom January 1977

TXCOOE* .Texas Stalutes (All titles, consitution and ALS)

IXINC* . Texas Secretary ol State corporation inlormation taken from corporale tiles

IXLTP. Texas Secretary of State timited partnership information
rXSOS* Combined TXINC and IXLIP lites

UTAH Utah Supreme Court from January 1965 Utah Court or Appeals from Aprd 1987

UTTAX Ulah Tax Commission decisions \& orders from August 1969

UTAG Ulah attorney general opinions from Jamuan 1977

UTCOOE* -Michie's Utah Code Annolated (Ant titles. constitution and ALS]

VT $\quad$-Vermont Supreme Court Irom Lamuary 1965

VTTAX -Vermonl Departmenl of Lax from May 1982

VICOOE" -Vermond Stalutes Annolaled (All titles constifution and ALST

VICOOE: : Lurgin Istands Code Amotaled and Revised Organic Act of 1954 (AIl tites and ALS)

VA -Virginia Supreme Court from Jaruary 1925 -Vrginia Court d Appeals from July 1985

VATAX -Virginia Departmen of Taxation rulings Irom June 1984

- Vuginia tax regulations eflective from January 1905

VAAG -Virginia atorney general opinions from tuly 1980

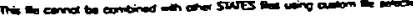

VACOOE* Michie's Code $\alpha$ Virginia (A littes constitution and ALST

WASH -Wastington Supreme Court from Jaruary 1938 -Washington Appeats Court from September 1969

WATAX Wastinglon Board of tax Appeals proposed and final decisions from Apri 1980

WASEC -Wastington Departmerl od Licensing Business Securities Division from 1974

WAPUC -Wastinglon Ut估ies and Mransportation Corrmission Irom July 1974

WAAG Wastington attomey general opinions from January 1977

WACOOE Revised Code od Wastrington (A) tites and constitution)

Wastington Chapter Laws

WA -West Virginia Suprente Coum from February 1965

WTAx West Virginia Departmenl od Tax and Revenue Administration decisions summaries lectmical assistance advisors and tax putrications Irom 1977

thest Virginia Stale Tax Department rules and regulations Irom June 1964

WAG -West Virginia attorney general opinions hom January 1977

WCODE*-Michie's West Virginia Code (All thtes constitution and ALS

WISC -Wisconsin Supreme Court trom January 1944 Wisconsin Appeals Court Irom August 1978

WITAX Wisconsin tax Appeals Commission from June 1978

WISEC Wisconsin Securities Commission Irom Jaruary 1970

WIPUC Wisconsin Public Utilities Commission Irom January 1979

WIAG Wisconsin atlorney general opinons from January 1977

WICOOE* Wisconsin Statutes (All chapters and constitution) Laws a Wisconsin

WISOS* Wisconsin Secretary or Slate corporation and fimited partnership indornation

Wro -Wyoming Supreme Count Irom January 1965

WYAG Wyoming attorney general opinions from January 1977

WrCOOE* -Michie's Wyoming Statutes Annotated (Afl tittes. constitution and ALS)

1SI Stale cases from 1st Circul

Maine

Massachusetis

New Hampstire

Rhode Istand

2ND Stale cases trom 2nd Circuit

Connecticut

New York

Vermon

380 Sale cases from 3rd Circur

Detaware

New Jersey

Pennsylvania 
North Carolina

Sounh Carolina

Virginia

West Virginia

5TH -Stale cases from 5 th Circuit Lovisiana

Mississippi

Texas

6TH State cases from 6th Circuil Kentucky

Michigan

Ohio

Tennessee

7TH -State cases from 7th Circuit Illinois

Indiana

Wisconsin

8TH State cases from 8th Circuin Arkansas

lowa

Minnesola

Missouri

Nebraska

North Dakota

South Dakota

9TH State cases Irom 9th Circuit

Alaska

Arizona

Calítornia

Hawaii

Idatho

Mondana

Nevada

Oregon

Wastinglon

10TH State cases Irom roth Circurt

Colorado

Kansas

New Mexico

Oklahoma

Ulah

Wyorsing

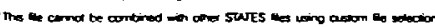

11TH -Stale cases from 11th Circuit Alabama

Florida

Georgia

HIGHCT -Highest counts from all states

ALLTAX -Taxing authority decisions from AK, AL, AZ CA, CO, DE, FL, GA. IL. IA. IN. KS, KY, LA MA, MD, Mi. MN, MO, MT, NH, NJ, NY,

OH, OK, OR. PA, SC, TN, TX, UT, VA, VT WA. $W$ and $W$

ALLSEC -State securities administrative decisions from $A Z, C A, F L, G A, I A, I L, K S$. KY, MA, MD, MI, MO, OK. OR, PA, TX. WA and $W$

ALLPUC -Public Utility Commission opinions from CA. CT. DE, FL. IL. IN, LA, MD, MI, MN, MO. NY. OH, PA, TX, WA and WI

ALLAG Alorney general opinions from AK. AL. AR, AZ, CA, CO. CT, FL. GA, HI, IA, ID. IL. IN, KS, KY LA, MA, MD, ME, MI, MO, MN, MS, MT, NC ND. NH, NJ. NM, NV. NY. OH, OK, OR, PA, SC SD. TN, TX. UT, VA. WA WN Wl and WT

ALLENV - Slate emironmental agency decisions from CA. FL. GA, iL. LA, NJ, NY. OH and PA

ALLCOE* All state statute malerials

OMNI All courts Irom all states and ALA annolations

OMNI2 All courts from all states

GR* Governmental Unit annual reports from July 1985 
APPENDIX D

DICTIONARY OF IDENTIFIERS FOR

PERSONAL (INDIVIDUAL) AND PUBLIC RIGHTS 


\section{NEWSPAPER ARTICLES}

\section{Personal (Individual) Rights}

Bergalis, Kimberly

children with AIDS (as a group in opposition to the public)

homopheliacs (as a group in opposition to the public)

homosexuals (as a group in opposition to the public)

Individual names

Ray family, Ray brothers

White, Ryan

workers/employees with AIDS (as a group in opposition to public)

\section{Public Rights}

Justice Department

officials seek identity of citizens

patients

people have right

public benefit

School Board of Nassau County (plaintiff)

Senate

\section{LEGAL DECISIONS}

Personal (Individual) Rights

individual names of persons as plaintiff(s)

\section{Public Rights}

blood banks as plaintiff(s)

Board of Education as plaintiff(s)

Citizens for Uniform Laws as plaintiff(s)

Citizens for Responsible Behavior as plaintiff(s)

In re: Complex Blood Bank Litigation

individual names of organizations as plaintiff(s)

on behalf of all others similarly situated as plaintiff(s)

School Board as plaintiff(s)

United States of America as plaintiff(s) 


\section{APPENDIX E}

DICTIONARY OF IDENTIFIERS FOR

MORAL BOUNDARY CONSTRUCTION AND MAINTENANCE 
NEWSPAPER ARTICLES

\section{Moral Boundary Construction}

adopts policy

approves/disapproves bill

approves/passes ordinance

barred from returning

cancel lesbian blood drive

challenge to policy

clinic has been closed

closing arguments

court decision

decision interprets

endorses recommendations

findings will determine

fined the sum of

jury decision

lawsuit

lawyers in case

legally correct/incorrect or justified/unjustified

new guidelines, rules, policy

organize boycott

reverse decisions

rules that

school board decision

seeking $\$$ from

Supreme Court

suspend

threaten to supersede

upholds policy

voted to bar

votes to change

won ruling

\section{Moral Boundary Maintenance}

articles not defined as "construction" categorized as

"maintenance"

no challenges to present laws, rules or guidelines 


\section{LEGAL DECISIONS}

\section{Moral Boundary Construction}

appellant(s)/petitioner(s) is plaintiff -- lower court decision is reversed in whole or in part by appellate court

appellant(s)/petitioner(s) is plaintiff -- lower court decision remanded back to lower court for further considerations

appellant(s)/petitioner(s) is defendant / lower court decision is affirmed

plaintiff(s) receives decision requiring some type of action from defendant(s)

\section{Moral Boundary Maintenance}

appellant(s)/petitioner(s) is plaintiff / lower court decision is affirmed by appellate court appellant(s)/petitioner(s) is defendant / lower court decision is reversed 